\title{
Site U1411
}

R.D. Norris, P.A. Wilson, P. Blum, A. Fehr, C. Agnini, A. Bornemann, S. Boulila, P.R. Bown, C. Cournede, O. Friedrich, A.K. Ghosh, C.J. Hollis, P.M. Hull, K. Jo, C.K. Junium, M. Kaneko, D. Liebrand, P.C. Lippert, Z. Liu, H. Matsui, K. Moriya, H. Nishi, B.N. Opdyke, D. Penman, B. Romans, H.D. Scher, P. Sexton, H. Takagi, S.K. Turner, J.H. Whiteside, T. Yamaguchi, and Y. Yamamoto ${ }^{2}$

\section{Chapter contents}

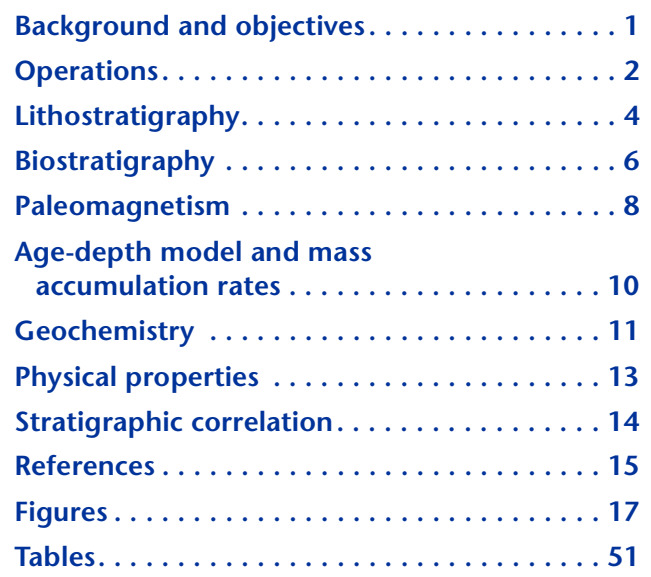

${ }^{1}$ Norris, R.D., Wilson, P.A., Blum, P., Fehr, A., Agnini, C., Bornemann, A., Boulila, S., Bown, P.R., Cournede, C., Friedrich, O., Ghosh, A.K., Hollis, C.J., Hull, P.M., Jo, K., Junium, C.K., Kaneko, M., Liebrand, D., Lippert, P.C., Liu, Z., Matsui, H., Moriya, K., Nishi, H., Opdyke, B.N., Penman, D., Romans, B., Scher, H.D., Sexton, P., Takagi, H., Turner, S.K., Whiteside, J.H., Yamaguchi, T., and Yamamoto, Y., 2012. Site U1411. In Norris, R.D., Wilson, P.A., Blum, P., and the Expedition 342 Scientists, Proc. IODP, 342: College Station, TX (Integrated Ocean Drilling Program). doi:10.2204/iodp.proc.342.112.2014 'Expedition 342 Scientists' addresses.

\section{Background and objectives}

Integrated Ocean Drilling Program (IODP) Site U1411 (proposed Site SENR-11A; $41^{\circ} 37.1^{\prime} \mathrm{N}, 49^{\circ} 00^{\prime} \mathrm{W}$; $\sim 3300 \mathrm{~m}$ water depth) is a mid-depth site ( 2850 meters below sea level [mbsl] paleodepth at $50 \mathrm{Ma}$ ) (Tucholke and Vogt, 1979) in the upper end of the Expedition 342 Paleogene Newfoundland sediment drifts depth transect (Fig. F1). The site is positioned to capture a record of sedimentation $\sim 1.65 \mathrm{~km}$ shallower than the largely sub-carbonate compensation depth (CCD) record drilled at Site U1403 (Figs. F2, F3). The location, well above the average late Paleogene CCD, should be sensitive to both increases and decreases in carbonate burial, whether these reflect variations in dissolution related to changes in the CCD, changes in carbonate production, or variations in background noncarbonate sedimentation. Our primary scientific objectives for drilling Site U1411 were

- To obtain an expanded record of the upper half of a Miocene-lower Eocene sediment drift to compare directly to the timing and nature of drift development at the Site U1407 and U1408 drift and the Site U1409 and U1410 drift;

- To recover an expanded record of the Eocene-Oligocene transition (EOT) in a clay-rich sequence where we expect unusually well preserved microfossil records for geochemical and faunal analysis;

- To capture fine-scale variations in carbonate preservation and lysocline shifts in Miocene-Eocene carbonate-rich sediment that is $\sim 550 \mathrm{~m}$ shallower than the Site U1406 Oligocene-Miocene section; and

- To evaluate the history of deep water and the CCD on sediment chemistry, grain size, and provenance.

Secondary objectives include the possible recovery of the Oligocene/Miocene boundary and events in the later Eocene for comparison with the record of these events elsewhere, particularly at Sites U1404-U1406 along the Expedition 342 depth transect.

Site U1411 was drilled to date the fourth and last Paleogene sediment drift of Expedition 342. Previous drilling demonstrated that all of the drifts were initiated in the middle early Eocene, but their times of termination vary from the early Miocene (J-Anomaly Ridge) to late middle Eocene (the two Southeast Newfoundland Ridge drifts). Drilling at Site U1411 aimed to refine our ideas of drift stratigraphy, particularly to test the time of cessation of drift growth. The end of drift growth is likely to record the time when 
the supply of clay and other noncarbonate components largely ceased or to indicate when currents became too strong to deposit fine-grained sediments around the volcanic seamounts on Southeast Newfoundland Ridge. Sedimentation rates fall in the JAnomaly Ridge drift in the late Eocene and again in the middle Oligocene, so we expect that these times could represent hiatuses or times of the cessation of drift sedimentation at Site U1411.

The calcareous sequence targeted at Site U1411 was expected to capture changes in ocean alkalinity and carbonate production. Sites U1403 and U1404 were mainly positioned to capture large-amplitude CCD deepening events, such as the carbonate budget "overshoots," that are thought to be associated with the most extreme climate perturbations of the Cenozoic, such as those involved with the Paleocene/Eocene Thermal Maximum (PETM), the late middle Eocene, and the EOT (see the "Site U1403" and "Site U1404" chapters [Norris et al., 2014b, 2014c]). Transient shoaling of the CCD in generally carbonaterich sequences should be recorded at Site U1411 by decreases in carbonate preservation and decreasing carbonate content relative to clay or biosiliceous sediment, as we have already observed at Sites U1405U1410. As a mid-depth site on the Newfoundland depth transect at $\sim 3300$ mbsl, Site U1411 was positioned to allow us to reconstruct small changes in carbonate content between the records of Sites U1406 (3850 mbsl), U1410 (3400 mbsl), and U1408 (3022 mbsl) and should have a few intervals in which the sediment is $80 \%-90 \%$ carbonate and also intervals in which carbonate abundance falls in the record. Carbonate content is expected to be generally higher at sites in shallower water depth, such as the majority of the sites located on Southeast Newfoundland Ridge, but less than our shallowest depth Sites U1407 and U1408.

The mix of high clay and carbonate contents anticipated in sediment at Site U1411 should produce unusually good microfossil preservation, as seen in other Expedition 342 sites. In turn, well-preserved fossils should permit construction of detailed stable isotope records and a calcareous microfossil biostratigraphy that can be tied by physical property records and magnetochronology to Sites U1403U1406, U1409, and U1410 further downslope and Sites U1407 and U1408 upslope. Ties between sites on Southeast Newfoundland Ridge and those on JAnomaly Ridge will allow the isotope stratigraphy and biochronology developed for Sites U1406U1410 to be exported to the lower ends of the depth transect.

Ultimately, the goal is to use the combination of the middle Eocene record at Sites U1407-U1411 and the younger Paleogene record at Site U1406 to produce composite stable isotope and carbonate content records that can be tied to the more intermittent geochemical records at Sites U1403-U1405. Our aim was to match carbonate-rich intervals across all of the JAnomaly Ridge sites with the sites on Southeast Newfoundland Ridge to create an orbital-resolution record of fluctuations in ocean chemistry and deep water origins.

We conclude that Site U1411 should provide an expanded record of primarily calcareous ooze and chalk of rough age-equivalence to sites in deeper water on J-Anomaly Ridge. In particular, Site U1411 should provide a high-deposition rate record of the Miocene, Oligocene, and Eocene as a counterpart to the largely sub-CCD record at Site U1403 and the shallower records at Sites U1405 and U1406. The combination of these records will improve age and water depth control on the behavior of the CCD in the North Atlantic during this key interval.

\section{Operations}

All times are local ship time (UTC -2.5 h). See Table T1 for coring summary.

\section{Hole U1411A summary}

Latitude: $41^{\circ} 37.0992^{\prime} \mathrm{N}$

Longitude: $48^{\circ} 59.9990^{\prime} \mathrm{W}$

Water depth below sea level (m): 3298.8

Date started: 1115 h, 25 July 2012

Date finished: 2320 h, 25 July 2012

Time on hole (days): 0.5

Seafloor depth ( $\mathrm{m}$ drilling depth below rig floor [DRF]): 3310.6

Seafloor depth estimation method: adopted from Hole U1411B

Rig floor to sea level (m): 11.78

Penetration depth ( $\mathrm{m}$ drilling depth below seafloor [DSF]): 9.5

Cored interval (m): 9.5

Recovered length (m): 9.87

Recovery (\%): 104

Total cores (number): 1

APC cores (number): 1

Drilling system: 117/16 inch advanced piston corer (APC)/extended core barrel (XCB) bit with $136.00 \mathrm{~m}$ bottom-hole assembly (BHA)

Objective: core from seafloor to 250 meters below seafloor (mbsf) or until science objectives are met

Result: missed mudline; abandoned Hole U1411A and began Hole U1411B 


\section{Hole U1411B summary}

Latitude: $41^{\circ} 37.0993^{\prime} \mathrm{N}$

Longitude: $48^{\circ} 59.9839^{\prime} \mathrm{W}$

Water depth below sea level (m): 3298.8

Date started: 2320 h, 25 July 2012

Date finished: 1310 h, 27 July 2012

Time on hole (days): 1.6

Seafloor depth (m DRF): 3310.6

Seafloor depth estimation method: mudline core

Rig floor to sea level (m): 11.81

Penetration depth (m DSF): 254.2

Cored interval (m): 254.2

Recovered length (m): 233.94

Recovery (\%): 92

Total cores (number): 28

APC cores (number): 20

$\mathrm{XCB}$ cores (number): 8

Drilling system: 11\%16 inch APC/XCB bit with $136.00 \mathrm{~m}$ BHA

Objective: core from seafloor to $250 \mathrm{mbsf}$

Result: target reached; objectives achieved

\section{Hole U1411C summary}

Latitude: $41^{\circ} 37.0890^{\prime} \mathrm{N}$

Longitude: $48^{\circ} 59.9856^{\prime} \mathrm{W}$

Water depth below sea level (m): 3300.18

Date started: 1310 h, 27 July 2012

Date finished: 0500 h, 29 July 2012

Time on hole (days): 1.7

Seafloor depth (m DRF): 3312.0

Seafloor depth estimation method: mudline core

Rig floor to sea level (m): 11.82

Penetration depth (m DSF): 223.9

Cored interval (m): 133.1

Recovered length (m): 118.62

Recovery (\%): 89

Drilled interval (m): 90.8

Drilled interval (number): 1

Total cores (number): 16

APC cores (number): 8

$\mathrm{XCB}$ cores (number): 8

Drilling system: 117/16 inch APC/XCB bit with $136.00 \mathrm{~m} \mathrm{BHA}$

Objective: core from seafloor to $\sim 250 \mathrm{mbsf}$

Result: objectives changed after starting hole to advance the hole by drilling to $100 \mathrm{~m}$ DSF and then resume coring operations; at 223.9 mbsf, a medical emergency terminated coring operations

\section{Description}

The vessel arrived at Site U1411 at $1115 \mathrm{~h}$ on 25 July 2012 after a $19.0 \mathrm{nmi}$ transit from Site U1410 that took $2.0 \mathrm{~h}$ at $9.5 \mathrm{kt}$. The plan for Site U1411 called for three holes to a depth of $\sim 250 \mathrm{~m}$ DSF. The first core for Hole U1411A failed to capture the mudline, and the hole was terminated after Core 342-U1411A$1 \mathrm{H}$. The second hole was successfully cored to 254.2 $\mathrm{m}$ DSF. The third hole was APC-cored to $9.2 \mathrm{~m} \mathrm{DSF}$, advanced by drilling $90.8 \mathrm{~m}$, and then cored to a total depth of $223.9 \mathrm{~m}$ DSF. Because of a medical emergency, the decision was made to terminate coring operations rather than coring a further, last hole at this site. Overall recovery for Site U1411 was 91.3\%. The total time spent at Site U1411 was 89.75 h (3.7 days).

\section{Hole U1411A coring}

After arriving at Site U1411, a short test was performed during the BHA to determine if the APC core barrel was in fact landing on the landing seat in the BHA. During the test, it was discovered that the core barrel was landing prematurely in the modified top sub. It was suspected that premature landing of the APC core barrel on the top sub was responsible for occasional premature partial shearing of APC pins when the FlexIT core orientation tool was deployed during earlier drilling operations. The modified top sub was changed out and the test was performed again to the satisfaction of all concerned.

The remainder of the drill string was tripped to just above mudline and Hole U1411A was spudded at $2320 \mathrm{~h}$ on 25 July. Core 342-U1411A-1H was $9.87 \mathrm{~m}$ long and therefore did not recover the mudline. Without confirmation of the mudline, it was decided to abandon Hole U1411A. The seafloor and water depths for Hole U1411A were adopted from Hole U1411B (seafloor at $3310.6 \mathrm{~m}$ DRF; $3298.8 \mathrm{mbsl}$ ). The seafloor was cleared at $2320 \mathrm{~h}$ on 25 July, ending Hole U1411A. Overall core recovery for Hole $\mathrm{U} 1411 \mathrm{~A}$ was $9.87 \mathrm{~m}$ for the $9.5 \mathrm{~m}$ interval recovered (103.9\% recovery). The total time spent on Hole U1411A was $12.00 \mathrm{~h}$.

\section{Hole U1411B coring}

The vessel was offset $20 \mathrm{~m}$ east. Hole U1411B was spudded at $0035 \mathrm{~h}$ on 26 July and recovered a $0.93 \mathrm{~m}$ long mudline core, establishing seafloor depth at $3310.6 \mathrm{~m}$ DRF (3298.8 mbsl). Cores 342-U1411B-1H through $20 \mathrm{H}$ were recovered to $177.4 \mathrm{~m}$ DSF using nonmagnetic core barrels and the FlexIt core orientation tool. The XCB was deployed for Cores $21 \mathrm{X}$ through $28 \mathrm{X}$ to a final depth of $254.2 \mathrm{~m}$ DSF. The seafloor was cleared at $1310 \mathrm{~h}$ on $27 \mathrm{July}$, ending Hole U1411B. The recovery for Hole U1411B was $233.94 \mathrm{~m}$ over the $254.2 \mathrm{~m}$ cored (92.0\% recovery). The total time spent on Hole U1411B was $38.00 \mathrm{~h}$. 


\section{Hole U1411C coring}

The vessel was offset $20 \mathrm{~m}$ south. Hole U1411C was spudded at $1505 \mathrm{~h}$ on 27 July and recovered a $3.2 \mathrm{~m}$ long mudline core, establishing the seafloor depth at $3312.0 \mathrm{~m}$ DRF (3300.18 mbsl). Cores 342-U1411C$1 \mathrm{H}$ through $2 \mathrm{H}$ were recovered to $9.2 \mathrm{~m}$ DSF. After Core $2 \mathrm{H}$, the hole was advanced by drilling without coring from 9.2 to $100.0 \mathrm{~m}$ DSF in order to save operational time for deeper objectives. After the drilling advance, APC coring continued with Cores $4 \mathrm{H}$ through 9H (100.0-152.2 m DSF). All APC cores were oriented with the FlexIt core orientation tool and recovered using nonmagnetic core barrels. The XCB was deployed for Cores 10X through 17X to a final depth of $223.9 \mathrm{~m}$ DSF. After recovery of Core 17X, a medical emergency terminated operations. The seafloor was cleared and the vessel was secured for transit at $0500 \mathrm{~h}$ on 29 July, ending Hole U1411C. The recovery for Hole U1411C was $118.62 \mathrm{~m}$ over the $133.1 \mathrm{~m}$ cored (89.1\% recovery). The total time spent on Hole U1411C was 39.75 h.

\section{Lithostratigraphy}

At Site U1411, we recovered a $254.5 \mathrm{~m}$ thick sedimentary succession of deep-sea sediment of Pleistocene to late Eocene age. The full sequence of sediment was only recovered from Hole U1411B. Hole U1411A was terminated after one core because of failed mudline recovery. Hole U1411C was washed down from 9.2 to 100.0 mbsf to ensure sufficient time for the recovery of the Eocene-Oligocene transition between 130 and 170 mbsf in the time available.

The sedimentary sequence at Site U1411 is composed of three lithostratigraphic units (Figs. F4, F5, F6, F7, F8, F9; Table T2). Unit I is a $14.45 \mathrm{~m}$ thick succession of Pleistocene sediment with alternating gray and reddish brown clayey foraminiferal ooze, gray silty sand with foraminifers, and brown to grayish brown silty clay with foraminifers. Minor lithologies include reddish brown clay and gray silty sand with foraminifers. Occasional sand-sized lithics and pebble-sized dropstones are also present (Fig. F5). The Pleistocene succession at Site U1411 is very similar to that drilled at the other Southeast Newfoundland Ridge sites but is, in general, more clay rich. The Unit I/II boundary is a sharp contact between the banded brown-gray Pleistocene sediment and the underlying greenish gray silty clay. Unit II is a $198.23 \mathrm{~m}$ thick succession of silty clay, clay with nannofossils, silty nannofossil clay, and clayey nannofossil ooze with silt of early Miocene to late Eocene age (Figs. F6, F8 $\square$ Minor lithologic accessories include prominent green glauconite- and chlorite-rich horizons.
The base of Unit II is defined by the occurrence of foraminifers as a common lithologic component (common to very abundant) and diminishing silt content. Unit III is $41.92 \mathrm{~m}$ thick and composed of greenish gray and dark greenish gray nannofossil clay with foraminifers, clayey nannofossil chalk with foraminifers, and clayey foraminiferal chalk. Laminated intervals, some of which are highly concentrated in foraminifers, are common in Unit III. Three lines of evidence suggest that these intervals have undergone significant reworking and winnowing by currents: the presence of (1) plane-parallel laminae, (2) foraminiferal sands, and (3) intraformational conglomerate with pebble-sized clasts of clayey nannofossil chalk.

Lithostratigraphic units and boundaries are defined by changes in lithology (as identified by visual core description and smear slide observations), physical properties, color reflectance $\left(\mathrm{L}^{*}, \mathrm{a}^{*}\right.$, and $\left.\mathrm{b}^{*}\right)$, and biogenic content (calcium carbonate and silica) (Fig. F4). The lithologic differences observed between units are primarily attributable to varying abundances of nannofossils, diatoms, radiolarians, and foraminifers (Figs. F8, F9). Lithologic descriptions are based on sediment recovered from Hole U1411B and refined with observations from Holes U1411A and U1411C.

\section{Unit I}

Intervals: $342-\mathrm{U} 1411 \mathrm{~A}-1 \mathrm{H}-1,0 \mathrm{~cm}$, to $1 \mathrm{H}-\mathrm{CC}, 16$ $\mathrm{cm}$; 342-U1411B-1H-1, $0 \mathrm{~cm}$, to $3 \mathrm{H}-3,95 \mathrm{~cm}$; 342-U1411C-1H-1, $0 \mathrm{~cm}$, to $2 \mathrm{H}-\mathrm{CC}, 8 \mathrm{~cm}$

Depths: Hole U1411A = 0-9.87 mbsf; Hole U1411B $=0-14.35$ mbsf; Hole U1411C = 0-9.24 mbsf

Age: Pleistocene

Lithology: nannofossil ooze to nannofossil foraminiferal ooze, silty clay with nannofossils or foraminifers, clay, and muddy foraminiferal sand

Unit I is an $\sim 14.35 \mathrm{~m}$ thick succession of the Pleistocene sediment typical of the Southeast Newfoundland Ridge sites. Major lithologies are interbedded on the decimeter scale and include gray and reddish brown (10YR 6/1 and 5Y 5/1) clayey foraminiferal ooze, gray (5Y 5/1) silty sand with foraminifers, and brown to pale brown (7.5YR $5 / 3$ to $10 \mathrm{YR} 6 / 3$ ) and gray to grayish brown $(7.5 \mathrm{YR} 6 / 1$ to $10 \mathrm{YR} 5 / 2)$ silty clay with foraminifers (Figs. F4, F5, F6, F7, F8, F9). Minor lithologies include strong brown (10YR 5/4) clay and light gray (2.5Y 5/1) silty sands with foraminifers (Figs. F4, F5, F8). Bioturbation is extensive to complete; discrete burrows are typically not apparent. Sand-sized lithics and pebble-sized dropstones (limestone, arkosic sandstone, and granite with redtill matrix cemented to surface) are common (Fig. F5). The Unit I/II boundary is a sharp contact with under- 
lying lower Miocene greenish gray (5GY 6/1) silty clay in Section 342-U1411B-3H-3, 95 cm (Fig. F6).

\section{Unit II}

Intervals: 342-U1411B-3H-3, $95 \mathrm{~cm}$, to $24 \mathrm{X}-\mathrm{CC}, 38$ $\mathrm{cm} ; 342-\mathrm{U} 1411 \mathrm{C}-4 \mathrm{H}-1,0 \mathrm{~cm}$, to $17 \mathrm{X}-1,64 \mathrm{~cm}$

Depths: Hole U1411B $=14.35-212.58$ mbsf; Hole $\mathrm{U} 1411 \mathrm{C}=100.00-214.94 \mathrm{mbsf}$ (drilled interval from 9.24 to $100.00 \mathrm{mbsf}$ )

Age: early Miocene to late Eocene

Lithology: silty clay, clay with nannofossils and silt, nannofossil clay, and clayey nannofossil ooze

Unit II is a $198.13 \mathrm{~m}$ thick succession of silty clay, silty clay with nannofossils, nannofossil clay with silt, clayey nannofossil ooze, clayey nannofossil chalk, and clayey nannofossil chalk with foraminifers (Figs. F4, F6, F8, F9). Colors vary among gray (2.5Y 5/1, 5Y 5/1, 2.5Y 6/1, and 5Y 6/1), dark gray (5Y $4 / 1$ and $2.5 \mathrm{Y} 4 / 1$ ), greenish gray (5GY 5/1 and $10 \mathrm{GY} 5 / 1$ ), and dark greenish gray (10Y 4/1). Lithologic accessories include dark green glauconite-rich horizons and dark gray to black concentrations of sulfides. Small blebs of angular, very fine quartz sand and silt on core surfaces are very common in the Miocene and Oligocene sediment of Unit II (Fig. F10). We interpret these blebs as formerly carbonatecemented coarse silt-sized clasts of silty quartzstone transported as ice-rafted debris. Moderate bioturbation and secondary sulfide mineralization in burrows produce prominent mottling that characterizes the Unit II appearance (Fig. F6). Discrete burrows include Planolites, Zoophycos, and Chondrites, which are particularly well defined in XCB cores (342-U1411B$20 X$ through 23X).

Unit II is differentiated from Unit I by a sharp contrast in color, the presence of glauconitic nodules and hardground (Fig. F6), reduced color variability at the core-length scale, a significant decrease in the abundance of foraminifers, and the absence of very common siliciclastic grains larger than very fine sand sized (Figs. F4, F6, F8, F9). The Unit II-III transition is defined by the presence (Unit III) or absence (Unit II) of foraminifers as a major lithologic component. It should be noted that smear slide data do not accurately reflect this transition. This is a result of the large size of Unit III foraminifers, which are not easily incorporated into smear slides. The high abundance of foraminifers in Unit III is clearly evident from examination of section-half surfaces.

Unit II contains an expanded record of the EoceneOligocene transition in Cores 342-U1411A-13H through $18 \mathrm{H}$ (discussed in detail below). The Eocene-Oligocene sequence is indicated lithologically by the presence of decimeter-scale beds of clayey nannofossil ooze and an increase in carbonate content on the basis of smear slide analyses, also seen in carbonate content data (Figs. F4, F11).

\section{Unit III}

Intervals: $342-\mathrm{U} 1411 \mathrm{~B}-25 \mathrm{X}-1,0 \mathrm{~cm}$, to $28 \mathrm{X}-\mathrm{CC}, 46$ $\mathrm{cm}$; $342-\mathrm{U} 1411 \mathrm{C}-17 \mathrm{X}-1,64 \mathrm{~cm}$, to $17 \mathrm{H}-\mathrm{CC}, 42$ $\mathrm{cm}$

Depths: Hole U1411B = 215.80-254.50 mbsf; Hole $\mathrm{U} 1411 \mathrm{C}=214.94-223.58 \mathrm{mbsf}$

Age: late Eocene

Lithology: clayey nannofossil chalk and clayey nannofossil chalk with foraminifers

Unit III is a $39.70 \mathrm{~m}$ thick sequence of greenish gray (10Y 5/1 and 10GY 5/1) to dark greenish gray (10Y $4 / 1$ ) clayey nannofossil chalk and clayey nannofossil chalk with foraminifers and greenish gray (5GY 5/1) nannofossil foraminiferal chalk and clayey foraminiferal chalk of Eocene age (Figs. F4, F6, F7, F8, F9). Minor lithologic components include common, thin, green glauconite- and chlorite-rich bands and sulfide blebs. Bioturbation is very well expressed on the XCB core surfaces. Finely detailed Zoophycos and Planolites burrows with inset Chondrites are common and produce a finely mottled core surface. In general, the degree of bioturbation is moderate to low and decreases downhole.

We observed an increasing occurrence of millimeterscale plane-parallel laminations with occasionally wavy and crenulated surfaces and increasing concentrations of foraminifers downhole from Section 342U1411B-26X-3, $87 \mathrm{~cm}$, to the base of Unit III. We interpret these features to reflect the influence of bottom currents (Fig. F7). An intraformational chalkpebble conglomerate composed of locally reworked clasts in a foraminiferal ooze matrix is further evidence for strong bottom currents and winnowing as the source of the foraminiferal chalk in Unit III. Disruptions in bedding, fine-scale faulting, and folded beds, common in Core 342-U1411B-28X, are the result of slumping. The degree to which bottom currents and slumping are associated is speculative, but at Site U1410 we also observed slump features in association with probable winnowed horizons.

\section{Lithostratigraphic unit summary}

At Site U1411, we recovered a $254.5 \mathrm{~m}$ thick sedimentary succession of deep-sea, pelagic sediment of Pleistocene to late Eocene age and an expanded record of the EOT. The sedimentary sequence at Site U1411 is composed of three lithostratigraphic units. Unit I is a $14.35 \mathrm{~m}$ thick succession of Pleistocene sediment typical of other Southeast Newfoundland Ridge sites composed of alternating gray and reddish 
brown clayey foraminiferal ooze, gray silty sand with foraminifers, and brown to grayish brown silty clay with foraminifers. Dropstones and sand-sized lithics are prominent in Unit I. Unit II is a $198.23 \mathrm{~m}$ thick succession of silty clay, clay with nannofossils, and silty nannofossil clay of early Miocene to late Eocene age. Nannofossil oozes are also present in Unit II but are only present in the interval immediately above the Eocene/Oligocene boundary. Small blebs of angular, very fine quartz sand and silt on core surfaces are very common in Unit II and are interpreted as formerly carbonate-cemented coarse silt-sized clasts of silty quartzstone transported as ice-rafted debris. Unit III is $41.92 \mathrm{~m}$ thick and composed of greenish gray and dark greenish gray nannofossil clay with foraminifers, clayey nannofossil chalk with foraminifers, and clayey foraminiferal chalk. Laminated intervals, some of which are extremely rich in foraminifers, are common in Unit III. The foraminifer sand is interpreted as evidence for significant reworking, winnowing, and downslope transport of foraminifers from the seamount crest. This interpretation is supported by seismic evidence that the middle Eocene crops out near the crest of the seamount.

\section{On the origin of silty sand blebs on core surfaces}

During Expedition 342, we noted the presence of small, 1-2 mm sized white blebs composed of highly angular, well-sorted, uncemented quartz silt and very fine grained sand within muddy lithologies. These blebs are very common on section-half surfaces (Fig. F10). We also found the same very fine, angular quartz sand present in the $63 \mu \mathrm{m}$ fraction of sieved sediment. A coarse sand-sized, presumably ice-rafted clast of very fine angular quartz silty sandstone was recovered from Section 342-U1411B-19H$1,140 \mathrm{~cm}$, and is similar in composition to the white blebs. The clast was thoroughly washed of its nannofossil claystone matrix and treated with dilute hydrochloric acid. The sandstone clast reacted vigorously, with bubbles emanating from within the clast, confirming that it was cemented by calcite. This suggests that the very common blebs were transported to J-Anomaly Ridge and Southeast Newfoundland Ridge as coarse sand-sized clasts but have become disaggregated because of dissolution of calcite cement or they could not withstand core splitting and washing intact. The compositional uniformity of the blebs and their persistence in the Oligocene-Miocene sediment of J-Anomaly Ridge and Southeast Newfoundland Ridge is enigmatic.

\section{The Eocene-Oligocene transition}

An expanded EOT section with excellent calcareous microfossil preservation was recovered at Site U1411 (see "Biostratigraphy") (Fig. F11). Sedimentation rates across the transition (including nannofossil Zones NP22, NP21, and NP19/20) were as high as 5 $\mathrm{cm} / \mathrm{k} . \mathrm{y} .$, much higher than comparable sedimentation rates of $<0.25$ to $0.6 \mathrm{~cm} / \mathrm{k} . \mathrm{y}$. at Sites U1404, U1406, and U1409 for the same interval. High mass accumulation rates (see "Age-depth models and mass accumulation rates") across the EOT may explain the subtle lithologic expression of the transition in comparison to the other J-Anomaly Ridge and Southeast Newfoundland Ridge sites.

The Chron C13r/C13n boundary can be used to approximate the EOT and is well resolved in Hole U1411B (Fig. F11). Just above this tentative chron boundary, color reflectance $\left(\mathrm{L}^{*}\right)$ decreases, but this largely coincides with core disturbance (flow-in). Sediment from Cores $342-\mathrm{U} 1411 \mathrm{~B}-15 \mathrm{H}$ to $17 \mathrm{H}$ are a slightly lighter greenish gray ( $5 \mathrm{Y} 6 / 1$ to $5 \mathrm{Y} 5 / 1)$ than surrounding intervals ( $5 \mathrm{Y} 4 / 1$ to $10 \mathrm{Y} 4 / 10$ ) and are composed of nannofossil clay with silt to clayey nannofossil ooze with silt. This relatively carbonate rich lower Oligocene interval at Site U1411 may represent the carbonate overshoot following the early Oligocene glaciation (Oi-1). The carbonate mass accumulation rate peak present at Site U1411 is temporally correlated with peaks observed at Sites U1404 and U1406.

\section{Biostratigraphy}

Coring at Site U1411 recovered a $255 \mathrm{~m}$ thick sequence of Pleistocene to upper Eocene clay and nannofossil clay. Nannofossils, planktonic foraminifers, and benthic foraminifers are present through most of the succession. A short barren interval occurs between the Pleistocene and lower Miocene-Eocene sequence. Radiolarians are only present in the uppermost Pleistocene. A relatively thin Pleistocene sequence overlies a lower Miocene to mid-Oligocene succession with relatively poor carbonate microfossil preservation followed by an expanded lower Oligocene through upper Eocene succession with excellent preservation of calcareous microfossils. The Eocene-Oligocene boundary transition has sedimentation rates of up to $\sim 3 \mathrm{~cm} / \mathrm{k}$.y.

Benthic foraminifers are generally rare (the "present" category) throughout the recovered succession with the exception of the Miocene to upper Oligocene, where they are abundant to dominant. Benthic foraminifer preservation is good to very good through 
most of the lower Oligocene to upper Eocene sequence recovered. Moderate to poor preservation occurs in the Miocene to upper Oligocene.

An integrated calcareous and siliceous microfossil biozonation is shown in Figure F12. An age-depth plot including biostratigraphic and paleomagnetic datums is shown in Figure F19. Datum and zonal determinations from nannofossils, planktonic foraminifers, and radiolarians are in close agreement. Microfossil and paleomagnetic datums are given in Table T3. A summary of calcareous and siliceous microfossil abundances and preservation is given in Figure F13.

\section{Calcareous nannofossils}

Calcareous nannofossil biostratigraphy is based on analysis of core catcher and additional working section half samples in Hole U1411B. Depth positions and age estimates of biostratigraphic marker events are shown in Table T4. Calcareous nannofossil occurrence data are shown in Table T5. Note that the distribution charts are based on shipboard study only and are, therefore, biased toward age-diagnostic species.

At Site U1411, the preservation of calcareous nannofossils is generally good and moderate to good in the lower Oligocene though upper Eocene and moderate or poor in the Pleistocene and lower Miocene through mid-Oligocene. The uppermost sediment in Hole U1411B contains frequent nannofossils of Pleistocene Zone NN19, indicated by the presence of Pseudoemiliania lacunosa in the uppermost Sample 342-U1411B-1H-CC (8.48 mbsf) and absence of discoasters through Sample 3H-3, $73 \mathrm{~cm}$ (14.13 mbsf). The interval from Sample 3H-3, $73 \mathrm{~cm}$ (14.13 mbsf), to $3 \mathrm{H}-5,80 \mathrm{~cm}$ (17.20 mbsf), is noncalcareous and does not contain nannofossils. The interval from Sample 3H-6, $90 \mathrm{~cm}$, to $6 \mathrm{H}-\mathrm{CC}(18.80-48.95 \mathrm{mbsf})$ yields poor to moderately preserved nannofossil assemblages with few age-diagnostic taxa, but the top of Triquetrorhabdulus carinatus in Sample 3H-6, $90 \mathrm{~cm}$ (18.80 mbsf), and absence of Dictyococcites bisectus suggests a correlation with Zones NN2-NP25. Samples 7H-CC through 28X-CC (53.38-254.46 mbsf) are assigned to Zones NP24-NP18 based on the occurrence of standard datums listed in Table T4. The Eocene/Oligocene boundary is identified by the top Hantkenina alabamensis planktonic foraminifer datum in Sample 342-U1411B-18H-4, 110-112 cm (158.21 mbsf), just above the top of Discoaster saipanensis in Sample 19H-CC (172.38 mbsf), which marks the top of Zone NP19/NP20. The Eocene/Oligocene boundary nannofossil assemblages are well preserved and broadly comparable to those seen at Site U1406.
Minor reworking is seen in Cores 342-U1411B-23X through $27 \mathrm{X}$, and a sample with significant middle Eocene (Zone NP16) reworking is present in Core 27X (Sample 27X-3, $63 \mathrm{~cm}$ ), in the vicinity of a thick foraminifer-rich sand layer.

\section{Radiolarians}

All core catcher samples from Hole U1411B were examined for radiolarians, and only the uppermost Sample 342-U1411B-1H-CC was found to contain them. This Pleistocene assemblage is similar to that reported at Site U1409 and is assigned to Zone RN17 based on the absence of Stylatractus universus. Underlying sediment is barren of radiolarians. Sample $14 \mathrm{H}-$ CC contains rare spumellarian radiolarians of uncertain age.

\section{Planktonic foraminifers}

Core catchers and additional samples from working section halves were examined in Hole U1411B. Samples contain planktonic foraminifers from Pleistocene through upper Eocene. Depth positions and age estimates of identified biostratigraphic marker events are shown in Table T6. The stratigraphic distribution of planktonic foraminifers is shown in Table T7.

Sample 342-U1411B-1H-CC (0.89 mbsf) contains Globorotalia truncatulinoides and Globorotalia inflata, indicative of a Pleistocene age (Zone PT1). Samples 2H-CC through 4H-CC (10.84-29.84 mbsf) contain poorly preserved assemblages with G. inflata, Globorotalia menardii, Globigerinoides ruber, Neogloboquadrina dutertrei, and Neogloboquadrina pachyderma without G. truncatulinoides. Because the nannofossil data suggest a Miocene age, these assemblages of Pleistocene planktonic foraminifers may reflect downhole contamination.

Sample 342-U1411B-5H-CC (39.34 mbsf) appears to be of Oligocene age, as suggested by its poorly preserved, low-diversity assemblage of Catapsydrax unicavus, Catapsydrax dissimilis, Globorotaloides suteri, and Globoquadrina venezuelana. Samples 6H-CC through 10H-CC (48.945-86.585 mbsf) are assigned an early Oligocene age (Zone O3) or older, based on the presence of Subbotina angiporoides. The top of Zone $\mathrm{O} 2$ is identified by the top of Turborotalia ampliapertura in Sample 11H-CC (96.25 mbsf), and the top of Zone O1 is defined in Sample 14H-CC (124.425 mbsf) by the top of Pseudohastigerina naguewichiensis and Pseudohastigerina micra. The top of Zone E16, which marks the Oligocene/Eocene boundary, is found in Sample $18 \mathrm{H}-4,110-112 \mathrm{~cm}$ (158.21 mbsf), based on the top of H. alabamensis. The tops of Cribrohantkenina inflata and Turborotalia 
cerroazulensis occur within Zone E16, in Samples $18 \mathrm{H}-\mathrm{CC}$ (162.45 mbsf) and 18H-6, 110-112 cm (161.21 mbsf), respectively. Core 342-U1411B-18H contains a rather complete succession of Hantkenina specimens and well-preserved specimens of other Eocene planktonic foraminifers, compared to the same time interval at Site U1406.

The upper Eocene interval from Sample 342U1411B-19H-CC (162.445 mbsf) to 26X-CC (235.15 mbsf) is characterized by clay-rich sediment hosting exceptionally well preserved ("glassy") foraminifers. Reworking of middle Eocene foraminifers is common through the upper Eocene (Cores 342-U1411B$21 \mathrm{X}$ through $28 \mathrm{X}$ ), although reworked specimens are readily distinguished from in situ individuals by poor to moderate preservation and brown staining of the reworked specimens. The core catcher samples of Cores $20 \mathrm{H}$ through $22 \mathrm{H}$ contain abundant lithic fragments and pebble-sized rocks, likely originating from fall-in from the top of the hole.

The top of Zone E15, defined by the top of Globigerinatheka index, occurs in Sample 342-U1411B-19H-CC (172.375 mbsf), and Zone E14, defined by the top of Globigerinatheka semiinvoluta in Sample 24X-CC (212.54 mbsf), ranges to the base of the hole (Sample 28X-CC; $254.46 \mathrm{mbsf})$.

\section{Benthic foraminifers}

Benthic foraminifers were examined semiquantitatively in core catcher samples from Hole U1411B. Additional working section half samples taken from Cores 342-U1411B-3H, $4 \mathrm{H}$, and $15 \mathrm{H}$ through $28 \mathrm{X}$ were examined for preservation and relative abundance of benthic foraminifers. Benthic foraminifers at this site are predominantly rare (the "present" category) relative to total sediment particles $>150 \mu \mathrm{m}$ in the lower Oligocene to upper Eocene, and more abundant in the Miocene and upper Oligocene (Fig. F13; Tables T8, T9).

Preservation of benthic foraminifer tests is generally good to very good in the lower Oligocene and upper Eocene, but poor to moderate in the Miocene and upper Oligocene succession.

The Pleistocene fauna of Sample 342-U1411B-1H-CC (0.89 mbsf) is well preserved and dominated by Oridorsalis umbonatus, Quinqueloculina sp., Uvigerina peregrina, and Uvigerina senticosa. Sample 2H-CC (10.84 mbsf) is moderately preserved and dominated by $P y$ rulina sp. and $U$. peregrina (Table T8).

The poorly preserved Miocene benthic foraminifer assemblage (Sample 342-U1411B-3H-CC; 20.26 mbsf) is characterized by a high-productivity fauna with abundant Pullenia quinqueloba, Stilostomella sp., and Stilostomella paleoceanica.
Samples 342-U1411B-4H-CC through 18H-CC (29.84-162.45 mbsf) show an Oligocene fauna dominated by infaunal taxa. Abundant calcareous taxa throughout this interval include Cassidulina subglobosa, Dentalina sp., Gyroidinoides spp., and stilostomellids (Stilostomella gracillima, Stilostomella lepidula, and Stilostomella subspinosa) (Table T8). In addition to the taxa described above, single samples are characterized by the abundant occurrence of Kalamopsis?, O. umbonatus, and Uvigerina rippensis. As also observed at sites on J-Anomaly Ridge, the dominance of infaunal taxa at Site U1411 suggests high-organic export flux to the seafloor or the prevalence of suboxic seafloor conditions during the Oligocene.

The underlying upper Eocene sequence shows benthic foraminifer assemblages that suggest a normal deepwater environment only sporadically dominated by infaunal species. Fauna are mainly dominated by C. subglobosa, Cibicidoides praemundulus, Dentalina sp., Nuttallides truempyi, P. quinqueloba, S. lepidula, S. subspinosa, and, in several samples, O. umbonatus. Sample 342-U1411B-24X-CC (212.54 mbsf) is exceptional in that it contains a benthic foraminifer assemblage dominated by the infaunal taxa Plectofrondicularia lirata and Plectofrondicularia cf. kerni.

\section{Paleomagnetism}

We completed a paleomagnetism study of APC and XCB cores from Holes U1411B and U1411C with the primary objective of establishing a magnetostratigraphic age model for the site. Cores from Hole U1411A were not measured because the hole was abandoned after the first core. Sediment from this first core was too disturbed to obtain a meaningful magnetic record. The natural remanent magnetization (NRM) of each archive section half was measured at $2.5 \mathrm{~cm}$ intervals before and after demagnetization treatment in a peak alternating field (AF) of $20 \mathrm{mT}$ for all cores from Hole U1411B. For cores from Hole U1411C, we only measured NRM after 20 $\mathrm{mT}$ demagnetization. Archive section half measurement data were processed by removing measurements made within $7.5 \mathrm{~cm}$ of section ends and from disturbed intervals described in the Laboratory Information Management System database. Cores 342U1411B-1H through 20H and 342-U1411C-2H through $9 \mathrm{H}$ were azimuthally oriented using the FlexIt orientation tool (Table T10). All other cores were not oriented.

We also collected 161 discrete samples from working section halves to verify the archive section half measurement data of Site U1411 sediment. Discrete samples were collected and stored in $7 \mathrm{~cm}^{3}$ plastic cubes and typically taken from the least disturbed region 
closest to the center of each section in Hole U1411B. Selected samples were subjected to NRM measurements after $20 \mathrm{mT}$ AF demagnetization. Seventeen samples were selected for step-wise demagnetization at $0,10,20,30,40$, and $60 \mathrm{mT}$. All discrete sample data are volume corrected to $7 \mathrm{~cm}^{3}$.

\section{Results}

Downhole paleomagnetism data after $20 \mathrm{mT}$ demagnetization are presented for Holes U1411B and U1411C in Figures F14 and F15, respectively. Similar to paleomagnetism results from previous Expedition 342 sites, section-half measurement data from XCB-recovered cores are difficult to interpret because of biscuiting and substantial core disturbance. We chose to interpret only results obtained from APC-recovered cores.

We report the following principal features in the paleomagnetism data at Site U1411. First, we observed three intervals of general magnetic intensity behavior. Second, inclinations measured from archive section halves are biased toward positive values, whereas declinations frequently cluster at $\sim 0^{\circ}$ and $\sim 180^{\circ}$.

\section{Magnetic intensity zonation}

Downhole magnetic intensity trends can be binned into three intervals. Magnetic intensity decreases rapidly from $\sim 10^{-2}$ to $\sim 10^{-4} \mathrm{~A} / \mathrm{m}$ from the top of the hole to $\sim 15$ mbsf. This decrease corresponds to lithostratigraphic Unit I, which is composed of gray to reddish brown interbedded Pleistocene nannofossil ooze, muddy foraminifer sand, and foraminiferal ooze with silty clay (see "Lithostratigraphy"). This rapid decrease in magnetic intensity is commonly observed in all paleomagnetism records of Pleistocene sediment from Expedition 342 and is most likely attributed to downhole reduction of iron oxides. Magnetic intensity remains relatively constant at $\sim 10^{-4} \mathrm{~A} / \mathrm{m}$ from $\sim 20$ to $140 \mathrm{mbsf}$; high-frequency, low-amplitude (approximately half of an order of magnitude) oscillatory variations are superposed on this general trend. This zone occurs within the Oligocene portion of lithostratigraphic Unit II, which is composed of greenish gray silty clay with nannofossils and nannofossil ooze. Magnetic intensity values increase by two orders of magnitude to $\sim 10^{-2} \mathrm{~A} / \mathrm{m}$ from $\sim 140$ to $\sim 160$ mbsf and remain high below this level to the bottom of the hole. The step to higher downhole magnetic intensity values occurs over the uppermost Eocene; we observed this trend at several other sites during the expedition. The lithostratigraphic Unit II/III boundary ( 213 mbsf) is not associated with a distinct change in magnetic inten- sity. The slightly higher intensity values recorded in Unit III probably reflect a more pervasive drilling overprint in these XCB-recovered intervals. The intensity zonation is coherent with variations in magnetic susceptibility; therefore, we conclude that these trends most likely reflect variations in the concentration of magnetic minerals, caused either by diagenesis, supply, or both.

\section{Inclination bias and declination clustering}

An inclination bias toward positive values observed in most archive-half data indicates a substantial drilling overprint even after $20 \mathrm{mT}$ AF demagnetization. Because of this strong inclination biasing, we often cannot identify paleomagnetism polarity solely based on shipboard inclination data. On the other hand, oriented APC-recovered cores often show $\sim 180^{\circ}$ alternations in declination values, which cluster at $\sim 0^{\circ}$ and $\sim 180^{\circ}$. We interpret intervals with declination values of $\sim 0^{\circ}\left(\sim 180^{\circ}\right)$ to indicate normal (reversed) magnetozones. A magnetozone with a primary normal polarity should not display inclinations less than $\sim 40^{\circ}$, barring sedimentary inclination-shallowing biases. Notably, intervals with $\sim 180^{\circ}$ declination almost always correspond to inclination values that are shallower than those in the intervals with declination of $\sim 0^{\circ}$. Thus, the drilling overprint mainly obscures the remanent inclination but not declination. This magnetic behavior is similar to the paleomagnetism results from Sites U1403, U1404, and U1410.

\section{Comparison between pass-through and discrete sample data}

AF demagnetization results for 98 discrete samples are summarized in Table T11. Of the 17 samples treated with a $60 \mathrm{mT}$ peak AF demagnetization field, only one sample from the APC-recovered interval reveals a reasonably stable magnetization (e.g., Fig. F16A). This sample has a remanent magnetization intensity strong enough to be measured by the onboard JR-6A spinner magnetometer. The remaining samples typically display NRM intensities that decrease by an order of magnitude following $20 \mathrm{mT}$ AF demagnetization. This behavior indicates that a drilling overprint probably obscures the primary magnetic signal. An example of such a magnetic overprint can be seen in Figure F16B. Nevertheless, these results are useful for verifying the $20 \mathrm{mT}$ passthrough paleomagnetism data from the archive section halves.

Magnetization intensity and declination are generally consistent between the discrete samples and the archive section half samples from APC-recovered intervals (Fig. F14). In contrast, inclinations 
measured in discrete samples from XCB-recovered intervals are often more shallow than their counterpart values in the archive section half from APC-recovered core intervals. These observations indicate that cores from XCB-recovered intervals have a relatively severe overprint.

\section{Magnetostratigraphy}

Shipboard results reveal two series of magnetozones. The first zone is observed in Cores 342-U1411B-1H through $2 \mathrm{H} \quad(\sim 1-11 \mathrm{mbsf})$ and 342-U1411C-1H through $2 \mathrm{H}(\sim 0-7 \mathrm{mbsf})$. The second series is observed between Cores 342-U1411B-4H and $20 \mathrm{H}$ ( 20-177 mbsf), and part of this series is between Cores 342-U1411C-7H and 8H ( 127-143 mbsf). These magnetostratigraphies can be correlated between both holes.

By utilizing radiolarian, foraminifer, and nannofossil biostratigraphic datums from Hole U1411B (see "Biostratigraphy"), we can correlate magnetozones to the geomagnetic polarity timescale (GPTS). The shipboard magnetostratigraphic age model is based on Hole U1411B, for which we have the most biostratigraphic datums. Extension of this age model to the magnetozonation observed in Hole U1411C is contingent on the accuracy of the stratigraphic correlation between holes, which is corroborated by lithologic horizons, biostratigraphic datums, and physical property features (see "Stratigraphic correlation"). Our correlation is presented in Table T12 and is shown in Figures F14, F15, and F17.

We correlate the magnetostratigraphy in Cores 342$\mathrm{U} 1411 \mathrm{~B}-1 \mathrm{H}$ and $2 \mathrm{H}$ to Chrons C1n (Brunhes) through upper C1r.3r ( 1.19 Ma at $10.4 \mathrm{mbsf})$. The magnetostratigraphy observed in Sections 342U1411B-4H-4 through 20H-1 is correlated to lower Chrons C8n.2n ( 25.9 Ma) through upper C15n $(\sim 35.0 \mathrm{Ma})$. We did not observe the top of Chron C12r, any of Chron C12n, or the bottom of Chron C11r in any hole at Site U1411 in this interval. We also did not observe Chrons C11n.1n and C11n.1r in any hole at Site U1411. Paleomagnetism data from archive section halves and discrete samples suggest a magnetostratigraphy can be developed in deeper intervals at Site U1411, but it cannot yet be resolved in sufficient detail with these data to correlate with confidence to the GPTS. We note, however, that given the foraminifer and nannofossil biostratigraphy, we expect to observe the Chrons C16 and C17 series in Cores 342-U1411B-23X through 28X. Magnetozone correlations for the uppermost $7 \mathrm{~m}$ of Hole U1411C are similar to Hole U1411B. Deeper in Hole U1411C, we can only interpret the top and bottom of Chron C13n at this time.
The correlations described above provide a shipboard chronostratigraphic framework for interpreting the Pleistocene, Oligocene, and late Eocene sediment drift record at Site U1411. The most salient implications of this age model are summarized below:

1. Site U1411 contains a nearly complete and expanded Oligocene record. Average linear sedimentation rates (LSRs) during the Oligocene at Site $\mathrm{U} 1411$ are $1.53 \mathrm{~cm} / \mathrm{k} . y$. , with a peak rate of $2.85 \mathrm{~cm} / \mathrm{k} . \mathrm{y}$. during the Chron C11 series (Fig. F19).

2. Unlike sediment records at previous sites, the Chron C9 series was recovered at Site U1411. However, the Chron C11r/C12n and C12n/C12r boundaries are not clearly identified in the shipboard paleomagnetism data, suggesting a hiatus of at least $\sim 0.5 \mathrm{~m} . \mathrm{y}$. in the lower Oligocene. This interval also corresponds to a $10 \mathrm{~m}$ zone of depressed natural gamma radiation (NGR) values (see "Physical properties"), a sharp lithostratigraphic contact in Section 342-U1411B-10H-5 (Fig. F8), and a hiatus inferred from nannofossil and foraminifer biostratigraphic datums (Fig. F19).

3. The EOT is highly expanded, with the approximate top of Chron C12r to the top of Chron C15n ( 3.9 Ma) represented over at least $83 \mathrm{~m}$ of recovered core. Average LSR during this time interval is $2.63 \mathrm{~cm} / \mathrm{k} . \mathrm{y}$., with a peak LSR of $5.02 \mathrm{~cm} /$ k.y. across the boundary. The Chron C13n/C13r boundary (33.705 Ma) is recognized in Section 342-U1411B-17H-1 between 100.0 and $110.0 \mathrm{~cm}$ ( 144.15 mbsf) (Fig. F18). In Hole U1411C, this boundary is located between Sections 342U1411C-8H-5, $140.0 \mathrm{~cm}$, and 8H-6, $10.0 \mathrm{~cm}$ ( 142.50 mbsf).

4. Shipboard paleomagnetism data indicate at least three cryptochrons within Chron C13r. The second and longest of these cryptochrons occurs in the same stratigraphic interval as the first downhole appearance of the Eocene marker foraminifer H. alabamensis (see "Biostratigraphy"). This cryptochron probably corresponds to Chron C13r.1n (Cande and Kent, 1995; Marino and Flores, 2002) and has the potential to provide an excellent chronostratigraphic tie point to other EOT records.

\section{Age-depth model and mass accumulation rates}

At Site U1411, we recovered a $255 \mathrm{~m}$ thick sequence of Pleistocene to upper Eocene clay and nannofossil 
clay. A relatively thin Pleistocene sequence overlies a lower Miocene to middle Oligocene succession, followed by an expanded lower Oligocene through upper Eocene succession. The Eocene-Oligocene boundary transition has sedimentation rates $>1.5$ $\mathrm{cm} / \mathrm{k} . \mathrm{y}$. and as high as $5.0 \mathrm{~cm} / \mathrm{k} . \mathrm{y}$. at the boundary.

Biostratigraphic datums and magnetostratigraphic datums from Hole U1411B (Table T3) were compiled to construct an age-depth model for this site (Fig. F19). A selected set of datums (Table T13) was used to create an age-depth correlation and calculate LSRs. Total mass accumulation rate (MAR), carbonate MAR (CAR), and noncarbonate MAR (nCAR) were calculated at 0.2 m.y. intervals using a preliminary shipboard splice rather than the sampling splice described in this volume (Table T13; Fig. F20).

\section{Age-depth model}

The age-depth model is tied to Pleistocene nannofossil and paleomagnetic datums in the upper $10 \mathrm{~m}$ of Hole U1411A. Nannofossil and paleomagnetic datums also provide the primary tie points that span the transition from the condensed Miocene to the expanded Oligocene sequence. At $92 \mathrm{mbsf}$, we infer a hiatus of $\sim 1.5 \mathrm{~m}$.y. based on nannofossil and foraminifer datums and the observation that the Chron $\mathrm{C} 11 \mathrm{r} / \mathrm{C} 12 \mathrm{n}$ and $\mathrm{C} 12 \mathrm{n} / \mathrm{C} 12 \mathrm{r}$ boundaries are not clearly identified in the shipboard paleomagnetic data and appear unusually condensed with respect to the background sedimentation rate. The presence of a hiatus at this interval is consistent with a $10 \mathrm{~m}$ broad zone of depressed NGR values in Cores 342U1411B-10H and $11 \mathrm{H}$ and a sharp lithostratigraphic contact in Section 342-U1411B-10H-5. For the interval that spans the Eocene/Oligocene boundary, the age-depth model is tied to paleomagnetic datums in the upper part and planktonic foraminifer and nannofossil datums in the lower part. All three datum types agree very well through this interval.

\section{Linear sedimentation rates}

Hole U1411B comprises four distinct phases in LSR:

1. A Pleistocene interval with moderate LSR of 1.27 $\mathrm{cm} / \mathrm{k} . \mathrm{y}$;

2. A condensed Pleistocene to upper upper Oligocene interval with a very low LSR of $0.06 \mathrm{~cm} /$ k.y.;

3. A lower upper Oligocene to lower Oligocene interval of moderate to high LSR, averaging 1.53 $\mathrm{cm} / \mathrm{k} . \mathrm{y} . ;$ and

4. Below the lower Oligocene hiatus noted above, a relatively expanded interval that extends from lowermost Oligocene to lower upper Eocene with an average LSR of $2.74 \mathrm{~cm} / \mathrm{k} . \mathrm{y}$.
The maximum LSR of $5.02 \mathrm{~cm} / \mathrm{k} . \mathrm{y}$. , which is recorded across the Eocene/Oligocene boundary, may be an artifact of the uncertainties associated with biostratigraphic datum calibrations.

\section{Mass accumulation rates}

MARs at Site U1411 are predominantly composed of noncarbonate sedimentary components, primarily clay; biogenic silica is very scarce at this site. MAR increases to $1-1.5 \mathrm{~g} / \mathrm{cm}^{2} / \mathrm{k}$.y. in the upper Oligocene and rises to $3 \mathrm{~g} / \mathrm{cm}^{2} / \mathrm{k}$.y. immediately above a $1 \mathrm{~m} . \mathrm{y}$. hiatus in the lower Oligocene (Table T14). Carbonate content peaks in the lowermost Oligocene and briefly becomes the principal sedimentary constituent at Site U1411 from a mass accumulation perspective. MAR decreases briefly across the Eocene/Oligocene boundary, but then increases to $\sim 4 \mathrm{~g} / \mathrm{cm}^{2} / \mathrm{k}$.y. during the upper Eocene.

\section{Geochemistry}

The geochemistry program during operations at Site U1411 included

- Analysis of interstitial gas compounds on headspace samples;

- Measurement of minor and trace element concentrations in interstitial water squeezed from whole-round samples from Hole U1411B; and

- Inorganic carbon, total carbon, and total nitrogen determinations of solid sediment samples from Hole U1411B.

\section{Headspace gas samples}

Headspace gas samples for routine safety monitoring were collected typically at a frequency of one sample per core in Hole U1411B (Table T15), generally in the bottom half of each core (i.e., Sections 4, 5, or 6). Methane increases very slightly downhole, with values between 2.11 and 4.12 ppmv. Higher molecular weight hydrocarbons were not detected in measurable amounts.

\section{Interstitial water samples}

Seventeen interstitial samples were squeezed from whole-round samples that were typically taken at a frequency of one per core in Hole U1411B (Table T16). Whole-round samples were collected immediately after the cores were sectioned on the catwalk. In some cases, disturbed cores or low recovery precluded whole-round sampling, as was the case with Cores 342-U1411B-1H, 12H, 19X through 22X, and $27 \mathrm{X}$, which were either too disturbed to collect a whole-round sample or were not recovered. 


\section{Results}

Salinity, pH, alkalinity, ammonium, manganese, iron, and sulfate

The interstitial fluid profiles of sulfate, alkalinity, and ammonium in Hole U1411B reflect typical changes associated with organic carbon cycling (Fig. F21). The downhole $\mathrm{pH}$ profile decreases from 7.9 to 7.2 over $8-85$ mbsf. Below 85 mbsf, the downhole trend becomes more uniform to $234 \mathrm{mbsf}$, with $\mathrm{pH}$ decreasing and salinity profiles near uniform. Alkalinity decreases downhole 3.2 to $2.5 \mathrm{mM}$ in the upper $170 \mathrm{~m}$, with a further, more rapid decrease from 204 to 253 mbsf.

Manganese concentrations decrease rapidly with depth in lithostratigraphic Unit I and the uppermost part of Unit II (see "Lithostratigraphy") to $47 \mathrm{mbsf}$ and then remain within $3-5 \mu \mathrm{M}$ to the bottom of the hole.

Sulfate concentrations are $28 \mathrm{mM}$ near the top of the recovered sequence and decrease to $\sim 20 \mathrm{mM}$ at the base of the sequence.

Ammonium concentrations increase downhole from 8 to $\sim 250 \mu \mathrm{M}$ at the base of the sequence. Ammonium concentrations in Hole U1411B are among the highest measured during Expedition 342.

\section{Calcium, magnesium, sodium, chloride, boron, and potassium}

Calcium concentrations in Hole U1411B increase downhole from 8 to $21 \mathrm{mM}$ throughout the sequence with no major superimposed inflections.

Magnesium concentrations are relatively uniform in the upper $95 \mathrm{~m}$, with concentrations of $52 \mathrm{mM}$. From 114 to 253 mbsf, magnesium concentrations decrease from 52 to $40 \mathrm{mM}$. Below this depth, the downhole magnesium profile becomes near uniform at concentrations of $44 \mathrm{mM}$.

Potassium concentrations decrease downhole in the upper $180 \mathrm{~m}$, with a pronounced minimum of 7.7 $\mathrm{mM}$ at $67 \mathrm{mbsf}$. Following the nadir of the excursion to minimum potassium concentrations, downhole potassium concentration decreases, with values falling from 11 to $6.7 \mathrm{mM}$.

Magnesium/calcium ratios show a steady decline from the top to the base of the sediment column.

Throughout the sequence, sodium and chloride show no discernible downhole trends. However, sodium and chloride concentrations are positively correlated throughout the sequence $\left(R^{2}=0.76\right)$.

Interstitial water boron concentrations increase downhole to a broad maximum from 375 to $500 \mu \mathrm{M}$ over the 0-100 mbsf interval and then show an over- all decrease downhole to $300 \mu \mathrm{M}$ near the bottom of the sequence (250 mbsf).

\section{Discussion}

Interstitial fluid constituents in Hole U1411B are consistent with consumption of organic matter under oxic to suboxic conditions. The typical succession of electron acceptor use during early diagenesis is manganese, followed by iron then sulfate (Berner, 1980). Elevated concentrations of manganese in the upper $30 \mathrm{~m}$ coupled with low iron concentrations within the upper $50 \mathrm{~m}$ of the sediment column indicate oxic to suboxic diagenesis driven by microbial reduction of manganese oxides. Iron oxide reduction increases below $50 \mathrm{mbsf}$, where manganese concentrations become uniform. High sulfate concentrations throughout the sequence indicate that interstitial fluid diagenesis does not proceed to sulfate reduction.

Overall, interstitial water profiles of potassium, calcium, and magnesium are consistent with those resulting from exchange through alteration of basaltic basement at depth (Gieskes and Lawrence, 1981). Potassium concentrations also indicate possible adsorption onto clay particles.

Laboratory experiments under controlled temperatures and pressures have shown that boron is leached from terrigenous sediments into fluids (e.g., James et al., 2003), and a study of Ocean Drilling Program Leg 186 interstitial water samples concluded that the removal of boron from clays and volcanic ash was responsible for boron enrichment in interstitial water (Deyhle and Kopf, 2002). Therefore, the broad downhole peak in concentrations at Site U1411 at 100 mbsf presumably indicates increased supply from the terrigenous sediment component in lithostratigraphic Unit II (see "Lithostratigraphy").

\section{Sediment samples}

Sediment plugs $\left(5 \mathrm{~cm}^{3}\right)$ for downhole analysis of sediment elemental geochemistry were taken from Cores 342-U1411B-1H through 27X at an average resolution of one sample per section, adjacent to the moisture and density (MAD) samples (Table T17).

\section{Results}

Concentrations of inorganic carbon vary from 0.04 to $6.6 \mathrm{wt} \%$ in Holes U1411A-U1411C (Table T17; Fig. F22). These concentrations are equivalent to $0-$ $60 \mathrm{wt} \% \mathrm{CaCO}_{3}$, assuming that all of the carbonate is calcite.

Carbonate concentrations are $5-50 \quad w t \%$ in lithostratigraphic Unit I and decrease to $0-20 \mathrm{wt} \%$ in Unit II, which is consistent with low carbonate levels 
observed in other Oligocene sequences recovered during Expedition 342. In the expanded lower Oligocene sequence, carbonate content increases to 60 $\mathrm{wt} \%$. Below the Eocene/Oligocene boundary in the lower part of Unit II, carbonate content decreases to $30 \mathrm{wt} \%$. Thereafter, carbonate content fluctuates between 30 and $40 \mathrm{wt} \%$ through the base of the sequence.

Total organic carbon and total nitrogen content fluctuates between 0 and $0.6 \mathrm{wt} \%$ and 0 and $0.14 \mathrm{wt} \%$, respectively.

\section{Discussion}

As with other sites at which the Eocene/Oligocene boundary was recovered (Sites U1404 and U1406), carbonate content shows the characteristic increase across the boundary followed by a decrease in carbonate within the lower Oligocene.

\section{Physical properties}

We completed physical property measurements on whole-round sections, section halves, and discrete samples from section halves in Holes U1411AU1411C. Gamma ray attenuation (GRA) bulk density, magnetic susceptibility, $P$-wave velocity, and NGR measurements were made on whole-round sections using the Whole-Round Multisensor Logger (WRMSL) and Natural Gamma Radiation Logger. Thermal conductivity measurements were also performed on whole-round sections for Hole U1411B before they were split. Compressional wave velocity on section halves was also measured at a frequency of two in each section (at $\sim 50$ and $100 \mathrm{~cm}$ ) using the $P$-wave caliper (PWC). For MAD analyses, one discrete sample was collected in each section from Hole U1411B (typically at $\sim 35 \mathrm{~cm}$ from the top of a section). The Section Half Multisensor Logger was used to measure spectral reflectance and point magnetic susceptibility on archive section halves.

\section{Magnetic susceptibility}

Overall, magnetic susceptibility ranges from 0 to 200 instrument units (IU) (Fig. F23). From the top of the hole to 14 mbsf (lithostratigraphic Unit I; see "Lithostratigraphy"), magnetic susceptibility is characterized by large-amplitude variations. Magnetic susceptibility abruptly decreases to $\sim 15$ IU at the Unit I/ II boundary ( 14 mbsf). In Unit II, from $\sim 14$ to 143 mbsf, magnetic susceptibility remains constant at $\sim 15$ IU. At 143 mbsf, magnetic susceptibility increases from 15 to 35 IU and remains constant at $\sim 40$ IU to the bottom of the hole. Throughout this lowermost interval, magnetic susceptibility values are characterized by small but high-frequency variations that correlate with variations in calcium carbonate content (see "Geochemistry").

\section{Density and porosity}

Two methods were used to evaluate bulk density at Site U1411. The GRA method provided a bulk density estimate from whole-round sections. The MAD method applied to 165 discrete samples from Site U1411 provided a second, independent measure of bulk density, as well as dry density, grain density, water content, and porosity.

Overall, MAD bulk density values vary between 1.4 and $2.0 \mathrm{~g} / \mathrm{cm}^{3}$. Changes in MAD bulk density are consistent with those observed in the GRA bulk density record (Fig. F23), although MAD values are $\sim 3 \%$ lower than GRA density values in the APC-cored section. In lithostratigraphic Unit I, bulk density increases downhole from 1.64 to $1.90 \mathrm{~g} / \mathrm{cm}^{3}$, but at the top of Unit II ( 14 mbsf), bulk density abruptly decreases to $1.5 \mathrm{~g} / \mathrm{cm}^{3}$. From the top of Unit II, bulk density steadily increases downhole to $\sim 1.9 \mathrm{~g} / \mathrm{cm}^{3}$ at $\sim 150$ mbsf; this pattern is typical of compaction. Notable features are the step increases in bulk density at $\sim 60,130$, and $145 \mathrm{mbsf}$, which could be indicative of sedimentation changes and possibly hiatuses. Between $150 \mathrm{mbsf}$ and the bottom of Hole U1411B, bulk density is relatively constant. In Holes U1411B and U1411C, GRA bulk density data show higher amplitude variations in XCB-recovered cores.

At Site U1411, water content and porosity vary between 23 and $55 \mathrm{wt} \%$ and 45 and 77 vol\%, respectively. From the top of the hole to $\sim 150$ mbsf, both parameters decrease gradually to $30 \mathrm{wt} \%$ and 52 vol\% for water content and porosity, respectively. However, between $\sim 8$ and 15 mbsf, in the lower part of Unit I, porosity and water content abruptly shift to lower values. Furthermore, the anomalous feature observed in the bulk density profile at $60 \mathrm{mbsf}$ is equally well expressed in the water content and porosity record. Even though not visually recognizable in the core or color profiles, this feature likely represents a hiatus. Below 150 mbsf, water content and porosity remain relatively constant and average 28.5 $\mathrm{wt} \%$ and $52 \mathrm{vol} \%$, respectively.

Grain density remains constant and generally varies between 2.7 and $2.8 \mathrm{~g} / \mathrm{cm}^{3}$ throughout Hole U1411B.

\section{$P$-wave velocity}

$P$-wave velocity was measured using the $P$-wave logger on all whole-round sections and using the PWC on undisturbed section halves from Holes U1411AU1411C. Whole-round and section-half data track 
one another exceptionally well (Fig. F24). Overall, $P$ wave velocity gradually increases downhole from 1500 to $1700 \mathrm{~m} / \mathrm{s}$, similar to the overall trends in bulk density and water content. These downhole trends are readily attributed to compaction. A distinct step down in velocity from 1590 to $1500 \mathrm{~m} / \mathrm{s}$ occurs at the transition between lithostratigraphic Units I and II. Between 180 mbsf and the bottom of the hole, $P$-wave logger measurements were not performed, but PWC measurements show higher variations associated with the change in coring methods from APC to XCB.

\section{Natural gamma radiation}

NGR values range from 16 to $50 \mathrm{cps}$ at Site U1411 and are distinguished by three major trends. First, NGR values increase from 21 to $50 \mathrm{cps}$ between 0 and 110 mbsf. Second, between 110 and $145 \mathrm{mbsf}$, NGR values decrease to 20 cps. Third, below 150 mbsf, NGR values remain constant and average $\sim 36$ cps (Fig. F24). NGR is anticorrelated to calcium carbonate content, with particularly low counts in the high-carbonate sediment of Unit I and at $~ 140 \mathrm{mbsf}$ in Unit II. High NGR counts occur in the low-carbonate intervals in the upper part of Unit II, between $\sim 60$ and 120 mbsf (see "Geochemistry").

\section{Color reflectance}

Color reflectance parameters $\mathrm{a}^{*}$ and $\mathrm{b}^{*}$ follow similar trends to one another in Holes U1411B and U1411C (Fig. F25). In lithostratigraphic Unit I, values average $\sim 4$ for $\mathrm{a}^{*}$ and $\sim 5$ for $\mathrm{b}^{*}$. At the contact between Units I and II, $\mathrm{a}^{*}$ decreases from 4 to -1.5 and $\mathrm{b}^{*}$ decreases from 5 to 0.8 . This change in color reflectance values distinguishes the transition between banded browngray Pleistocene age sediment and the underlying greenish gray silty clay (see "Lithostratigraphy"). In Units II and III, $a^{*}$ and $b^{*}$ values remain constant and average 0.0 and -0.8 , respectively. Peaks in the $\mathrm{b}^{*}$ record, such as those at $\sim 34,45$, and 60 mbsf, correspond to yellowish horizons. The peak at 238 mbsf corresponds to a foraminifer sand-rich horizon in Core 342-U1411B-27X.

$\mathrm{L}^{*}$ can be correlated among Holes U1411B and U1411C (Fig. F25). Between the top of the hole and $\sim 100$ mbsf, $\mathrm{L}^{*}$ decreases slightly from 53 to 40 . Below, $\mathrm{L}^{*}$ increases to 51 at $\sim 140 \mathrm{mbsf}$ and remains constant at $\sim 45$ to the bottom of the hole. Some cyclic variations superimpose these downhole trends, such as at $\sim 18,60,150$, and 238 mbsf. The major variations in $\mathrm{L}^{*}$ recorded at Site U1411 correlate well to the magnetic susceptibility and NGR data series (Fig. F24) and appear to correlate to changes in calcium carbonate content (see "Geochemistry").

\section{Thermal conductivity}

Twenty-five thermal conductivity measurements were collected on whole-round sections from Hole U1411B (Table T18). Overall, thermal conductivity values increase downhole (Fig. F26). Thermal conductivity data are elevated $(\sim 1.65 \mathrm{~W} /[\mathrm{m} \cdot \mathrm{K}])$ in lithostratigraphic Unit I, probably because of the presence of foraminifer sand in these intervals. Thermal conductivity values gradually increase downhole from $\sim 1.1$ to $1.4 \mathrm{~W} /(\mathrm{m} \cdot \mathrm{K})$ throughout Units II and III.

\section{Stratigraphic correlation}

\section{Sampling splice}

We constructed a sampling splice for Site U1411 that consists of a series of floating continuous intervals from $\sim 0$ to $\sim 20, \sim 100$ to $\sim 171, \sim 172$ to $\sim 196$, and $\sim 213$ to $233 \mathrm{~m}$ core composite depth below seafloor (CCSF) (Fig. F27). The splice is based on a combination of shipboard physical property measurements (primarily magnetic susceptibility) for the 0 to 108 and $\sim 193$ to $\sim 233 \mathrm{~m}$ CCSF intervals and shore-based $\mathrm{X}$-ray fluorescence (XRF) core scanning measurements of calcium/iron ratio for the $\sim 108$ to $\sim 193 \mathrm{~m}$ CCSF interval. The large number of appended cores in the splice from $\sim 20$ to $\sim 100 \mathrm{~m} \mathrm{CCSF}$ is a result of time constraints; the drilling strategy was to advance without recovery through much of the upper $\sim 100$ mbsf of Hole U1411C to target prioritized stratigraphic intervals. The appended cores between $\sim 171$ and $242 \mathrm{~m} \mathrm{CCSF}$ are the result of a number of XCB cores with poor recovery from Holes U1411B and U1411C. Hole U1411B spans the thickest sediment column recovered at this site, with a maximum depth for the bottom of Core 342-U1411B-28X of 254.5 mbsf (274.02 m CCSF). Hole U1411C extends to a maximum depth of 223.9 mbsf $(242.26 \mathrm{~m}$ CCSF). As a result, we append the last three cores in Hole U1411B as well as the last core in Hole U1411C at the bottom of the splice. Our correlation yields a growth rate of $8 \%$ for Hole U1411B and 9\% for Hole U1411C (Fig. F28). The affine table (Table T19) summarizes the individual offsets for each core drilled.

\section{Correlation during drilling operations}

To aid correlation during drilling operations at Site U1411, we assessed magnetic susceptibility and GRA bulk density data collected at $2.5 \mathrm{~cm}$ resolution on the Special Task Multisensor Logger before allowing cores to equilibrate to room temperature. Magnetic susceptibility is low (<30 IU) between $\sim 13$ and $149 \mathrm{~m}$ CCSF, but it was still possible to guide drilling operations. From 149 to 274 m CCSF, magnetic suscepti- 
bility is higher ( 30-70 IU), which improved our ability to correlate in real time.

Hole U1411A was ended after one core because it did not recover a mudline. Hole U1411B switched to XCB coring for Core 342-U1411B-21X, but recovery for Cores $21 \mathrm{X}$ and $22 \mathrm{X}$ was $<10 \%$, leaving a large gap between $\sim 177$ and 196 mbsf.

The strategy for Hole U1411C was to drill without recovery through the upper portion of the sediment column after recovering the first two cores. As a result, Core $342-\mathrm{U} 1411 \mathrm{C}-3 \mathrm{H}$ is labeled in the affine table as a drilling advance of $\sim 92 \mathrm{~m}$. Recovery in Hole U1411C resumed at $\sim 106 \mathrm{~m} \mathrm{CCSF}$, and with minor drilling adjustments, we were able to offset coring gaps across most of the EOT.

\section{Correlation and splice construction}

Shipboard stratigraphic correlation and splice construction were based on magnetic susceptibility data and verified by NGR data. These two data series generally show clear, correlatable features throughout the sediment column (see "Physical properties"). However, in order to improve confidence in the splice across the EOT for sampling, we collected $\mathrm{Ca}$ / Fe measurements using the Avaatech XRF core scanner at Scripps Institution of Oceanography. We scanned the archive halves of Cores 342-U1411B$12 \mathrm{H}$ through $20 \mathrm{H}$ and $342-\mathrm{U} 1411 \mathrm{C}-4 \mathrm{H}$ through $12 \mathrm{X}$ and verified and/or adjusted the shipboard composite depth scale and tie points using measured elemental ratios. Our correlation is consistent with biostratigraphic and paleomagnetic results (see "Biostratigraphy" and "Paleomagnetism").

We defined Core 342-U1411C-1H as the anchor in our splice because it is longer than Core 342U1411B-1H, whereas Core 342-U1411A-1H did not recover a mudline. We appended cores from Hole U1411B from $\sim 20$ to $108 \mathrm{~m}$ CCSF because Hole U1411C did not recover sediment in this interval. We added offsets to these cores (Table T19) to eliminate overlap between successive cores in Hole U1411B. We used XRF Ca/Fe data from 108 to 193 $\mathrm{m}$ CCSF to identify ties (Fig. F29), though there are two tentative tie points in this interval based on small ( $1 \mathrm{~m}$ or less) overlap between successive cores. The apparent gaps in the splice in Figure F27 at 119.00-120.00, 127.29-129.52, and 130.32-131.29 $\mathrm{m} \mathrm{CCSF}$ are because of damage to the core liners of Sections 342-U1411C-5H-2, 6H-3, 6H-4, and 6H-7, which prevented the generation of WRMSL data. The tie points in these intervals are based on XRF elemental data. We used magnetic susceptibility to select tie points from $\sim 193$ to $\sim 233$ m CCSF where we did not collect XRF core scanner data. A tentative tie point at $\sim 224 \mathrm{~m} \mathrm{CCSF}$ is also the result of small over- lap between successive cores. The large gap from $\sim 195$ to $213 \mathrm{~m}$ CCSF is the result of poor recovery in both holes, suggesting that this gap is attributable to the formation. Finally, data from Core 342-U1411B$27 \mathrm{X}$ is not shown in Figure F27 because damage to the core liner prevented collection of WRMSL magnetic susceptibility data; however, we append this core below the splice.

The Site U1411 splice (Table T20) can be used as a sampling guide across the EOT, particularly from $\sim 108$ to $171 \mathrm{~m}$ CCSF, which is the longest stratigraphically continuous interval in the splice.

\section{References}

Berner, R.A., 1980. Early Diagenesis: A Theoretical Approach: Princeton, NJ (Princeton Univ. Press).

Cande, S.C., and Kent, D.V., 1995. Revised calibration of the geomagnetic polarity timescale for the Late Cretaceous and Cenozoic. J. Geophys. Res.: Solid Earth, 100(B4):6093-6095. doi:10.1029/94JB03098

Deyhle, A., and Kopf, A., 2002. Strong B enrichment and anomalous $\delta^{11} \mathrm{~B}$ in pore fluids from the Japan Trench forearc. Mar. Geol., 183(1-4):1-15. doi:10.1016/ S0025-3227(02)00186-X

Norris, R.D., Wilson, P.A., Blum, P., Fehr, A., Agnini, C., Bornemann, A., Boulila, S., Bown, P.R., Cournede, C., Friedrich, O., Ghosh, A.K., Hollis, C.J., Hull, P.M., Jo, K., Junium, C.K., Kaneko, M., Liebrand, D., Lippert, P.C., Liu, Z., Matsui, H., Moriya, K., Nishi, H., Opdyke, B.N., Penman, D., Romans, B., Scher, H.D., Sexton, P., Takagi, H., Turner, S.K., Whiteside, J.H., Yamaguchi, T., and Yamamoto, Y., 2014a. Methods. In Norris, R.D., Wilson, P.A., Blum, P., and the Expedition 342 Scientists, Proc. IODP, 342: College Station, TX (Integrated Ocean Drilling Program). doi:10.2204/iodp.proc.342.102.2014

Norris, R.D., Wilson, P.A., Blum, P., Fehr, A., Agnini, C., Bornemann, A., Boulila, S., Bown, P.R., Cournede, C., Friedrich, O., Ghosh, A.K., Hollis, C.J., Hull, P.M., Jo, K., Junium, C.K., Kaneko, M., Liebrand, D., Lippert, P.C., Liu, Z., Matsui, H., Moriya, K., Nishi, H., Opdyke, B.N., Penman, D., Romans, B., Scher, H.D., Sexton, P., Takagi, H., Turner, S.K., Whiteside, J.H., Yamaguchi, T., and Yamamoto, Y., 2014b. Site U1403. In Norris, R.D., Wilson, P.A., Blum, P., and the Expedition 342 Scientists, Proc. IODP, 342: College Station, TX (Integrated Ocean Drilling Program). doi:10.2204/

iodp.proc.342.104.2014

Norris, R.D., Wilson, P.A., Blum, P., Fehr, A., Agnini, C., Bornemann, A., Boulila, S., Bown, P.R., Cournede, C., Friedrich, O., Ghosh, A.K., Hollis, C.J., Hull, P.M., Jo, K., Junium, C.K., Kaneko, M., Liebrand, D., Lippert, P.C., Liu, Z., Matsui, H., Moriya, K., Nishi, H., Opdyke, B.N., Penman, D., Romans, B., Scher, H.D., Sexton, P., Takagi, H., Turner, S.K., Whiteside, J.H., Yamaguchi, T., and Yamamoto, Y., 2014c. Site U1404. In Norris, R.D., Wilson, P.A., Blum, P., and the Expedition 342 Scientists, Proc. IODP, 342: College Station, TX (Integrated Ocean 
Drilling Program). doi:10.2204/

iodp.proc.342.105.2014

Gieskes, J.M., and Lawrence, J.R., 1981. Alteration of volcanic matter in deep-sea sediments: evidence from the chemical composition of interstitial waters from deep sea drilling cores. Geochim. Cosmochim. Acta, 45(10):1687-1703. doi:10.1016/ 0016-7037(81)90004-1

Gradstein, F.M., Ogg, J.G., Schmitz, M.D., and Ogg, G.M. (Eds.), 2012. The Geological Time Scale 2012: Amsterdam (Elsevier).

James, R.H., Allen, D.E., and Seyfried, W.E., Jr., 2003. An experimental study of alteration of oceanic crust and terrigenous sediments at moderate temperatures (51 to $350^{\circ} \mathrm{C}$ ): insights as to chemical processes in near-shore ridge-flank hydrothermal systems. Geochim. Cosmochim. Acta, 67(4):681-691. doi:10.1016/S00167037(02)01113-4
Kirschvink, J.L., 1980. The least-squares line and plane and the analysis of palaeomagnetic data. Geophys. J. R. Astron. Soc., 62(3):699-718. doi:10.1111/j.1365246X.1980.tb02601.x

Marino, M., and Flores, J.A., 2002. Middle Eocene to early Oligocene calcareous nannofossil stratigraphy at Leg 177 Site 1090. In Gersonde, R., and Hodell, D.A. (Eds.), Southern Ocean Eocene-Pleistocene Stratigraphies: Insights from Ocean Drilling. Mar. Micropaleontol., 45:383-398. doi:10.1016/S0377-8398(02)00036-1

Tucholke, B.E., and Vogt, P.R., 1979. Western North Atlantic: sedimentary evolution and aspects of tectonic history. In Tucholke, B.E., Vogt, P.R., et al., Init. Repts. DSDP, 43: Washington, DC (U.S. Govt. Printing Office), 791825. doi:10.2973/dsdp.proc.43.140.1979

Publication: 3 March 2014

MS 342-112 
Figure F1. Bathymetric map for northwestern Southeast Newfoundland Ridge, northeast of J-Anomaly Ridge. Data are based upon multibeam mapping by KNR179-1 site survey. Single-channel seismic reflection profiles shown in Figures F2 and F3.

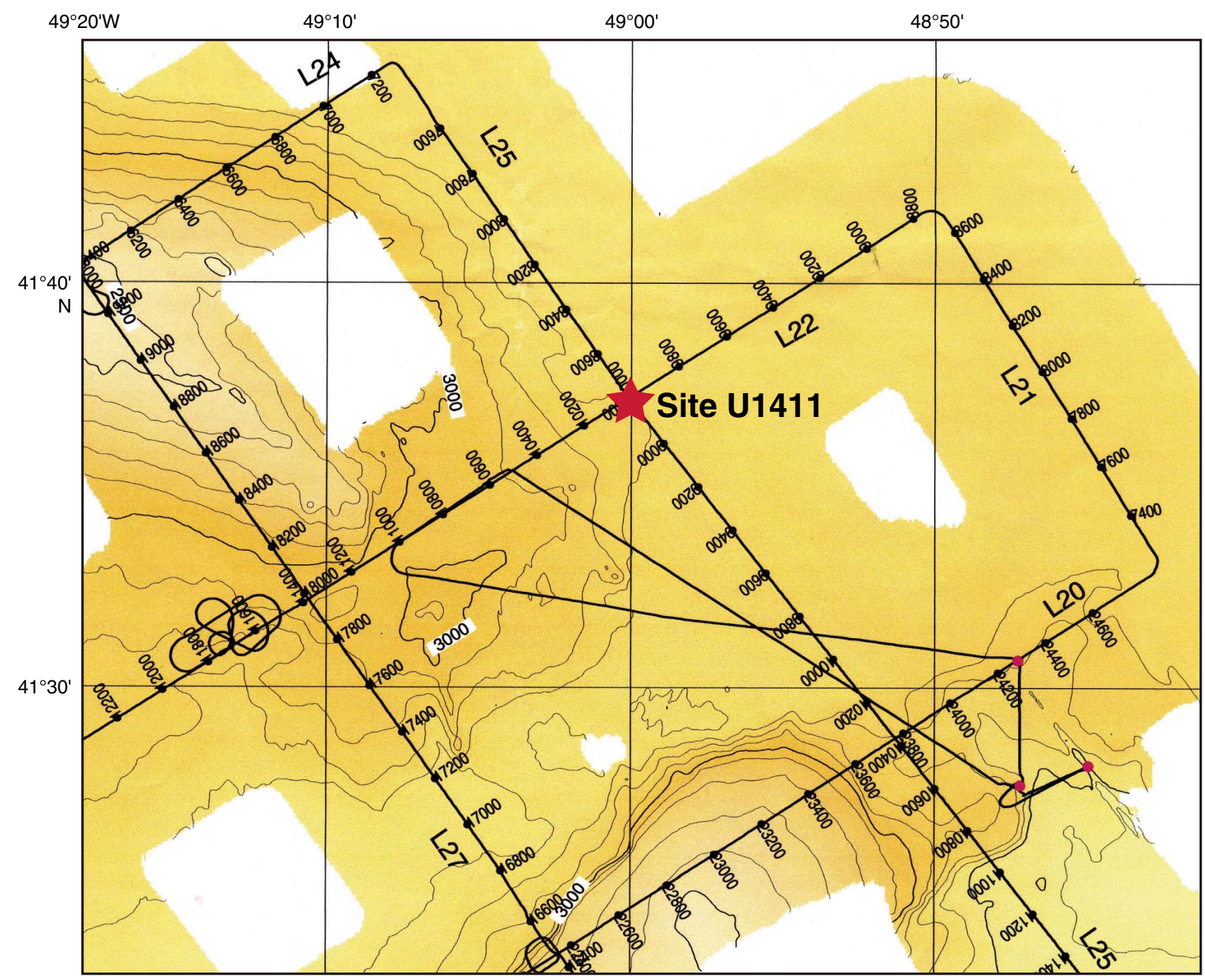


Figure F2. Single-channel seismic KNR179-1 Line 22. This is the southwest-northeast line crossing Site U1411 (at shotpoint [SP] 10000). White bar represents approximate depth of penetration at Site U1411.

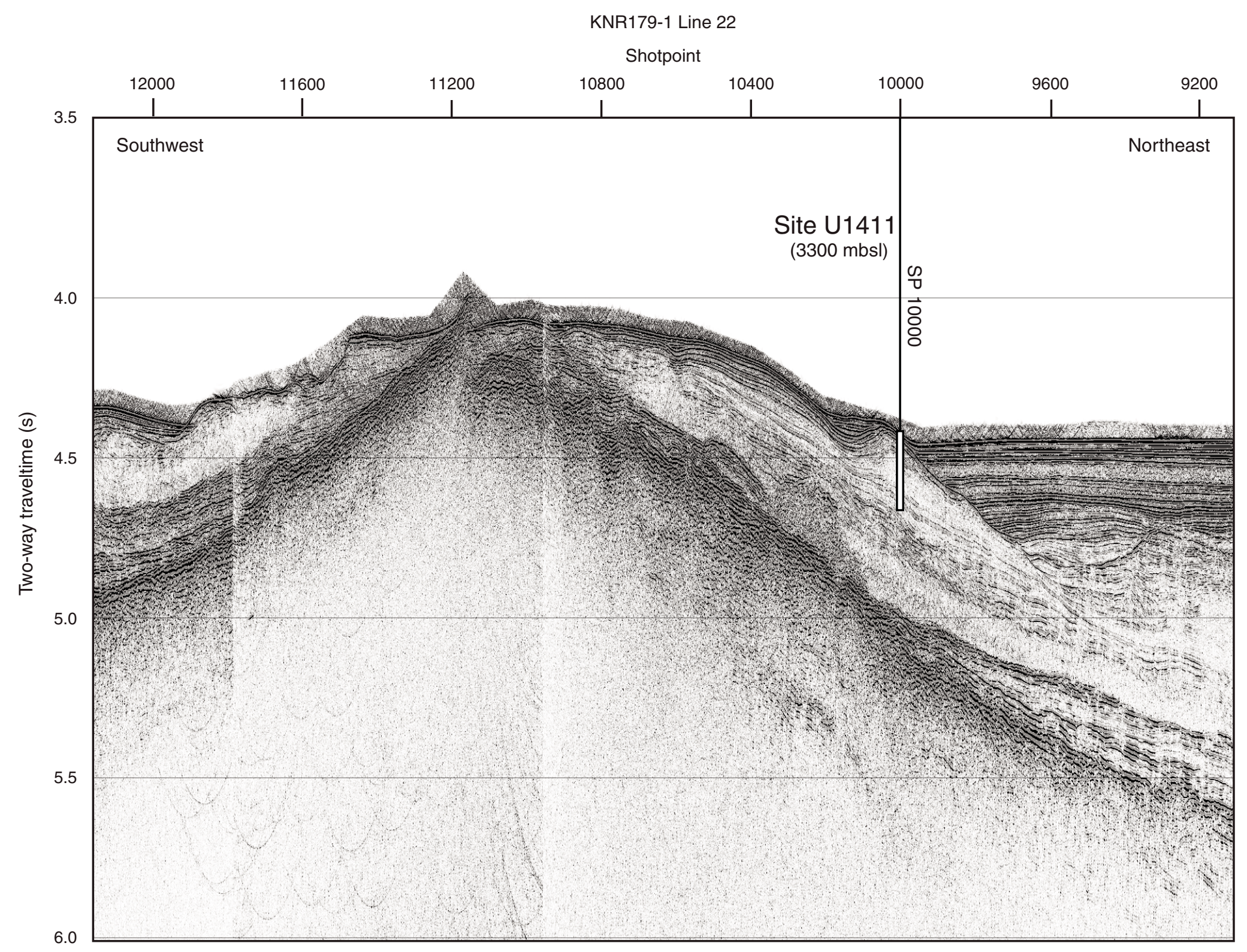


Figure F3. Single-channel seismic KNR179-1 Line 25. This is the northwest-southeast line passing through Site U1411 (at shotpoint [SP] 8800). White bar represents approximate depth of penetration at Site U1411.

KNR179-1 Line 25

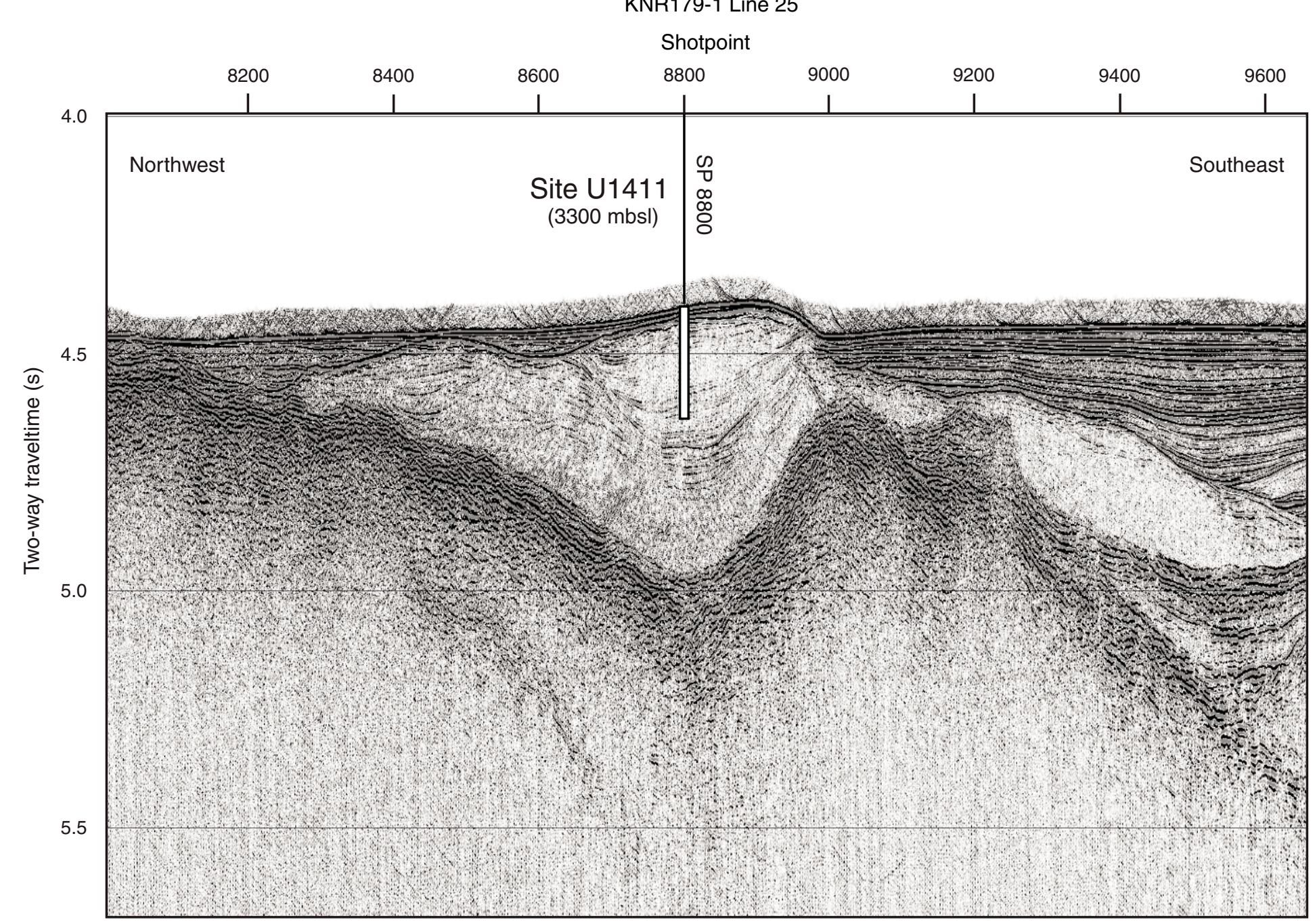


Figure F4. Lithostratigraphic summary, Site U1411. Typically, lighter colors reflect higher carbonate content.

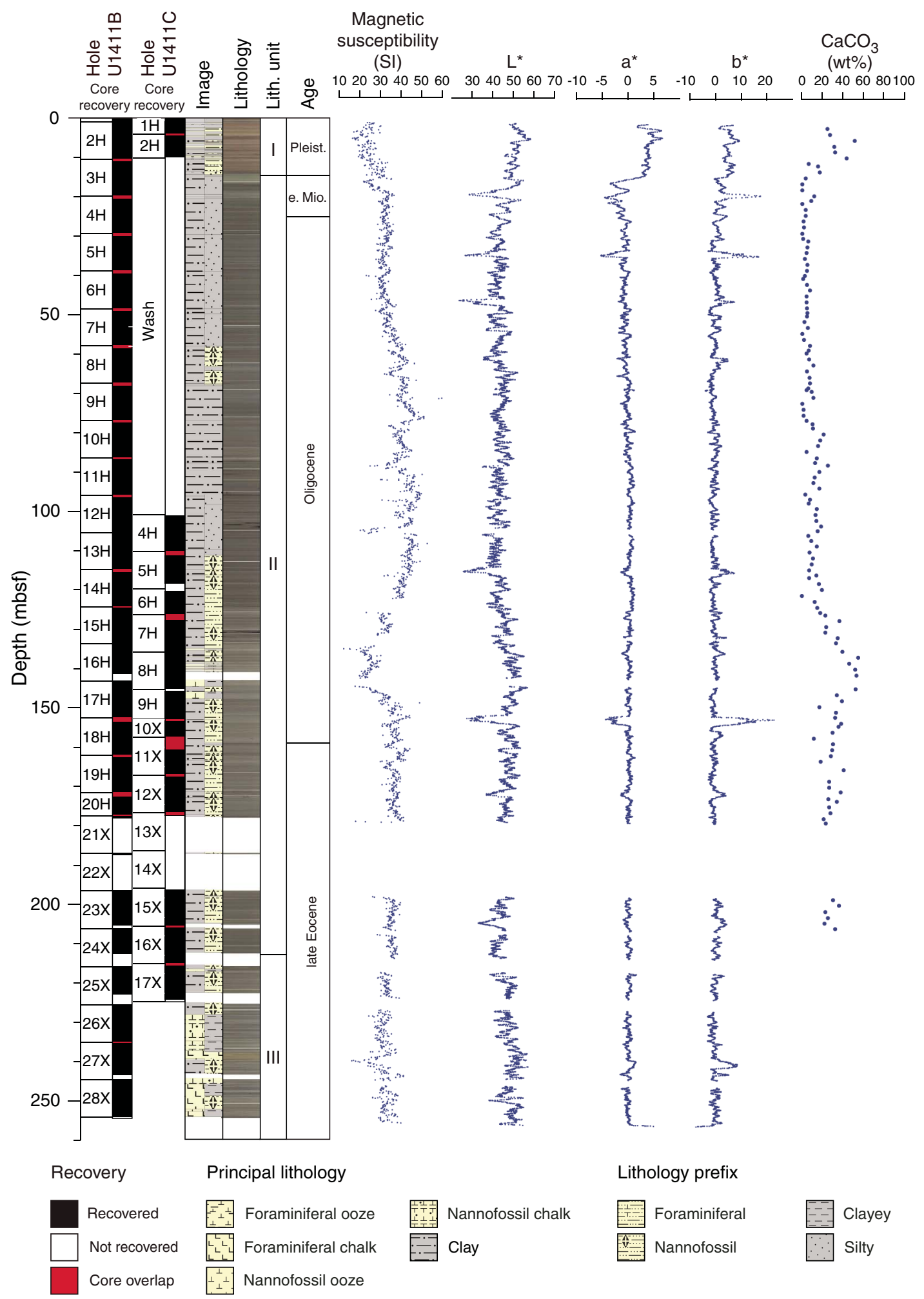


Figure F5. Core images from representative Unit I lithologies, Hole U1411B. A. Silty foraminiferal ooze with nannofossils hosting a granite dropstone with partially cemented reddish brown till matrix. B. Silty clay with foraminifers hosting a red, arkosic sandstone dropstone. C. Reddish brown (7.5YR 4/5) clay layer underlain by grayish brown $(2.5 \mathrm{Y} 5 / 2)$ silty clay with foraminifers. The bleb at the bottom of the image is a quartz and lithic sand lens rich in foraminifers. D. Quartz and lithic sand with foraminifers overlying a very fine silty sand.

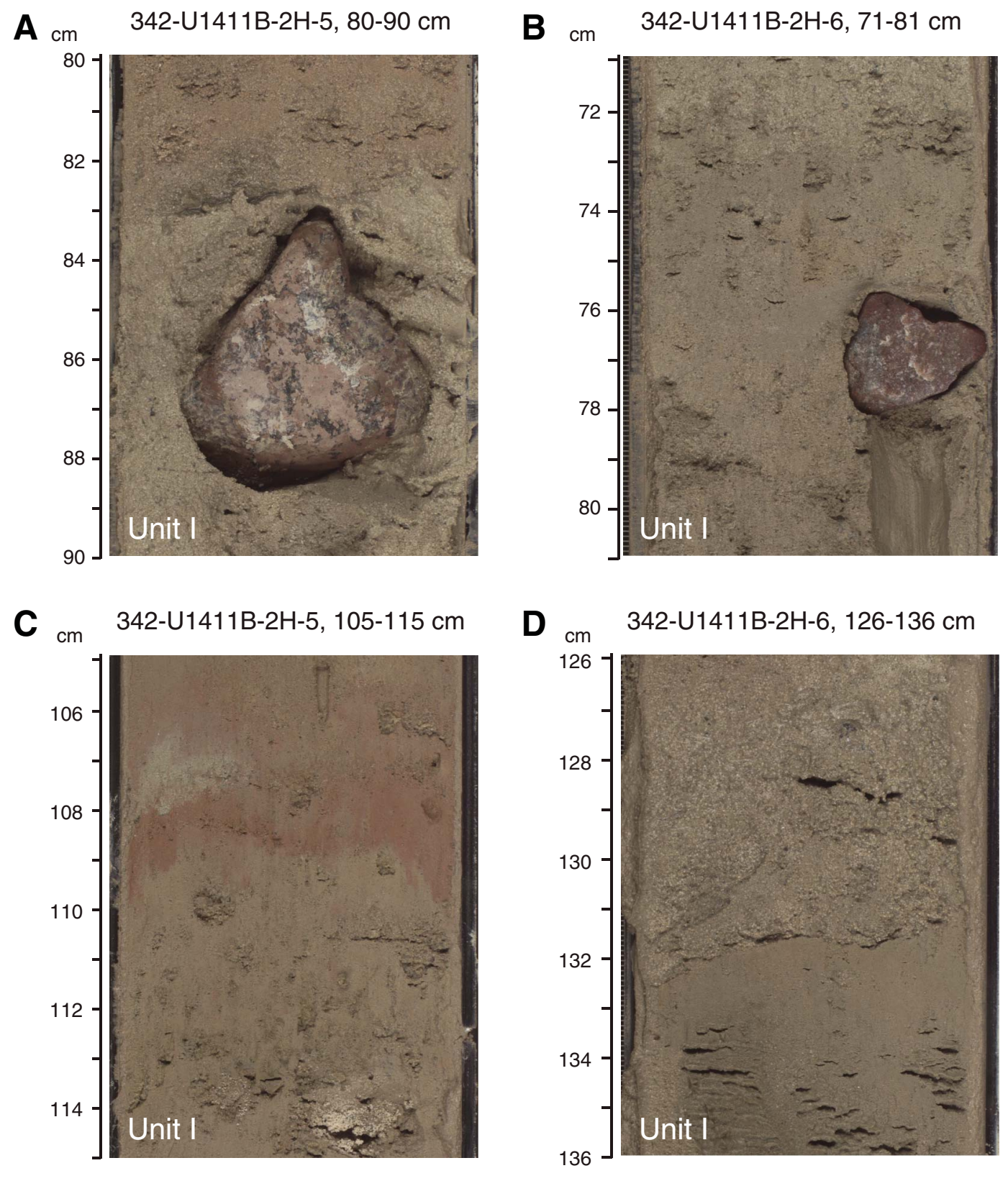


Figure F6. Core images from representative Unit II and III lithologies, Hole U1411B. A. Glauconitic hardground separating Unit I from Unit II. B. Blebs of concentrated very fine quartz silty sand in silty clay with nannofossils of Oligocene age. C. Representative silty clay with nannofossils with sulfide mottling. D. Zoophycos burrows with secondary sulfide mineralization. E. Laminated foraminiferal chalk with possible slumping features.
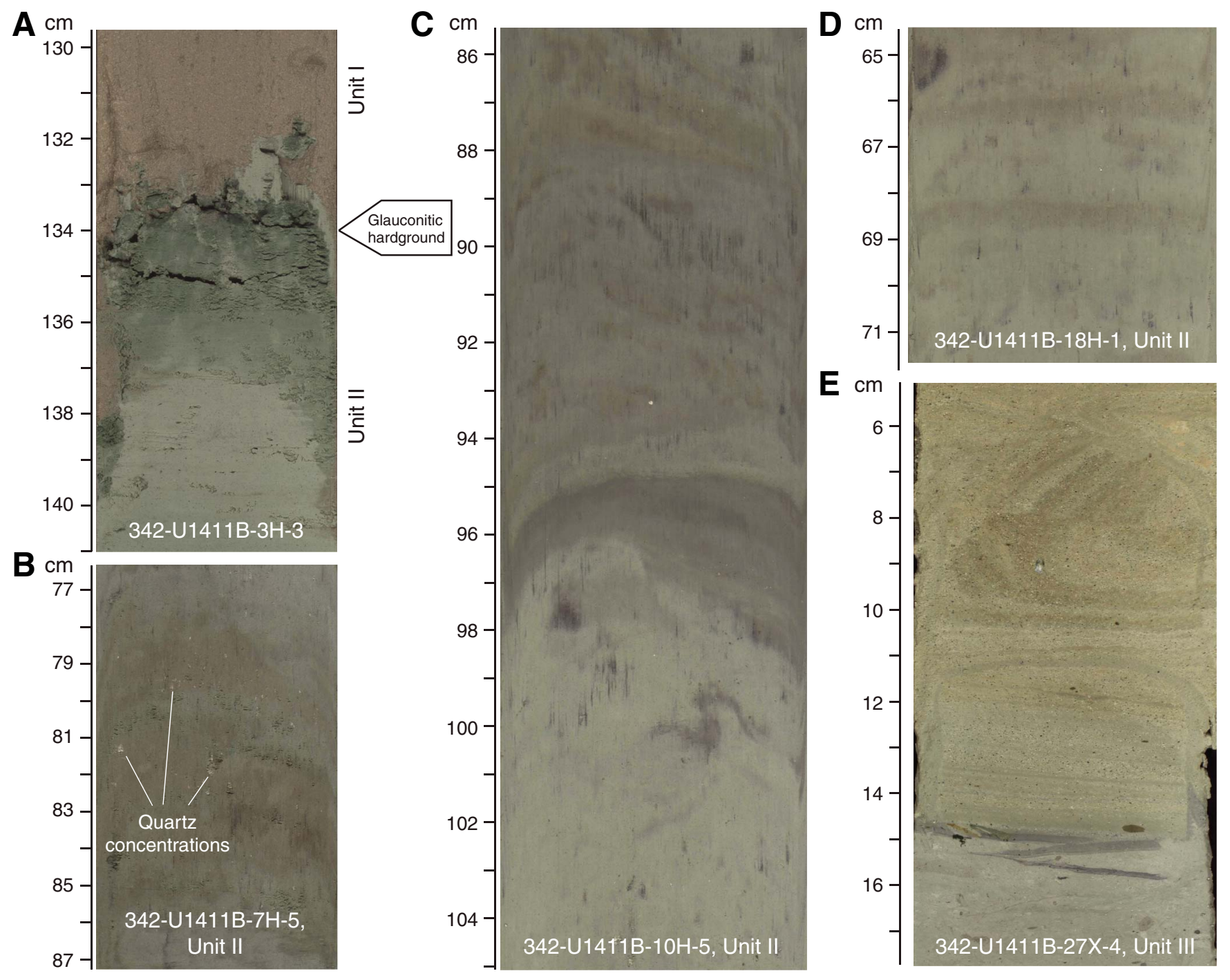

E

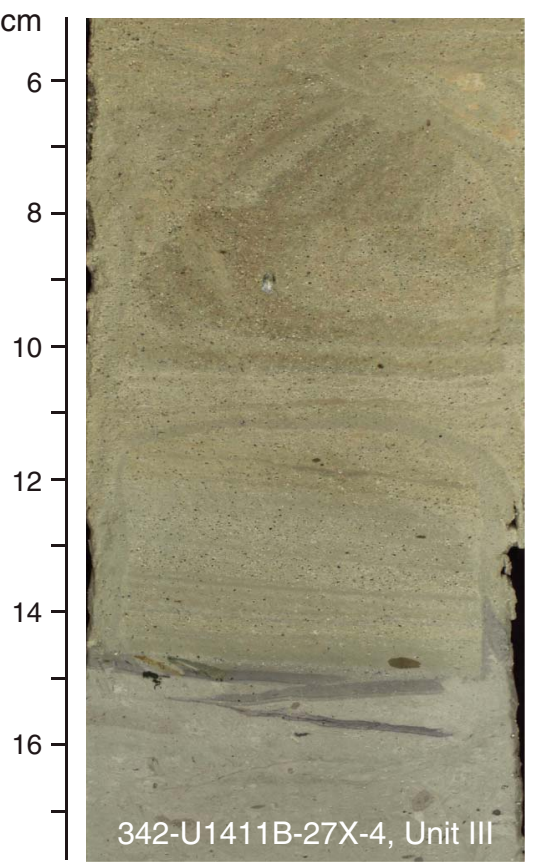


Figure F7. A. Section images of winnowed and occasionally laminated foraminiferal chalk, Core U1411B-27X. B. Small clasts within nannofossil chalk. C. Nannofossil chalk with foraminifers to foraminiferal chalk transition. D. Lithology of foraminiferal chalk.

A Core 342-U1411B-27X, Unit III

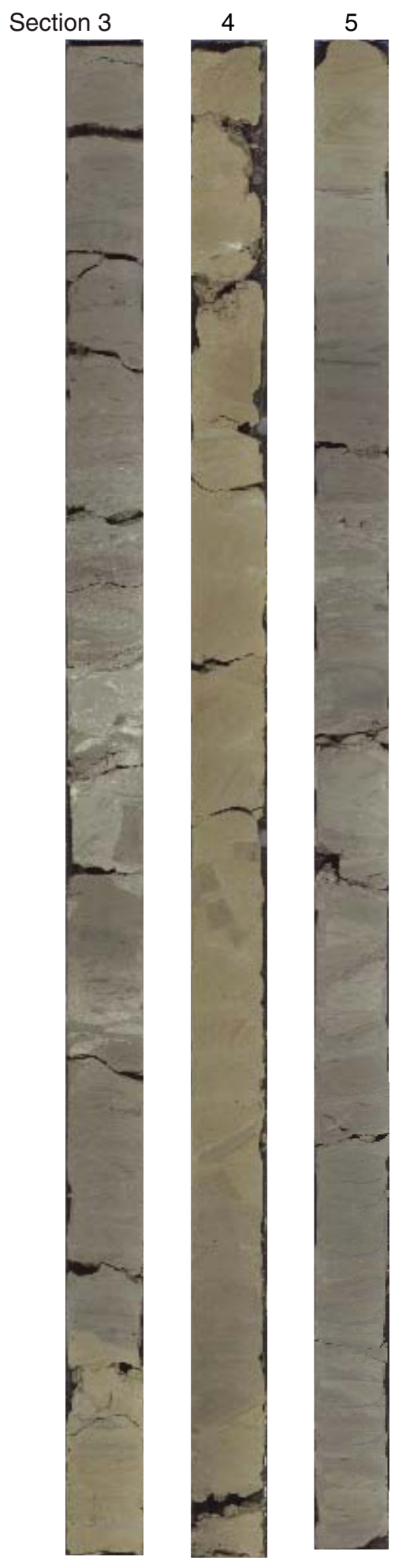

B 342-U1411B-27X-3, 46-59 cm

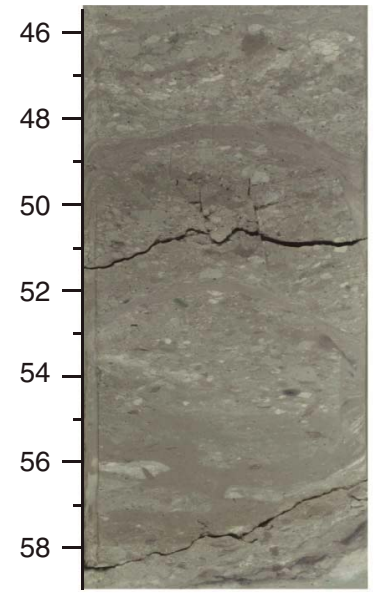

C $342-U 1411 \mathrm{~B}-27 \mathrm{X}-3,118-132 \mathrm{~cm}$

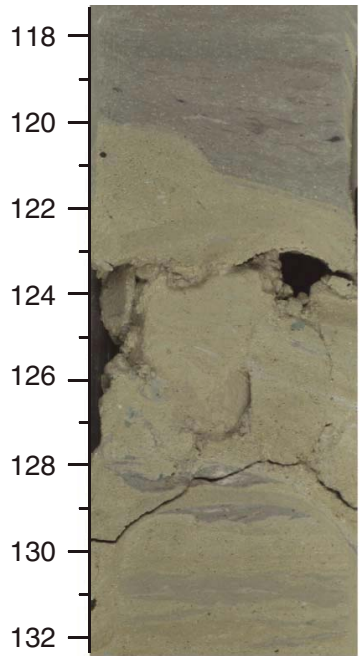

D 342-U1411B-27X-4, 62-64 cm

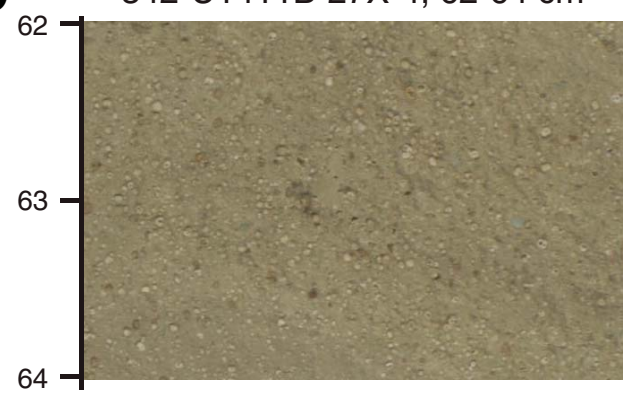


Figure F8. Photomicrographs of smear slides indicating the dominant lithologies of Units I-III, Site U1411. A. Clay with silt. B. Nannofossil clay. C. Nannofossil ooze with clay. D. Foraminiferal nannofossil chalk with clay.
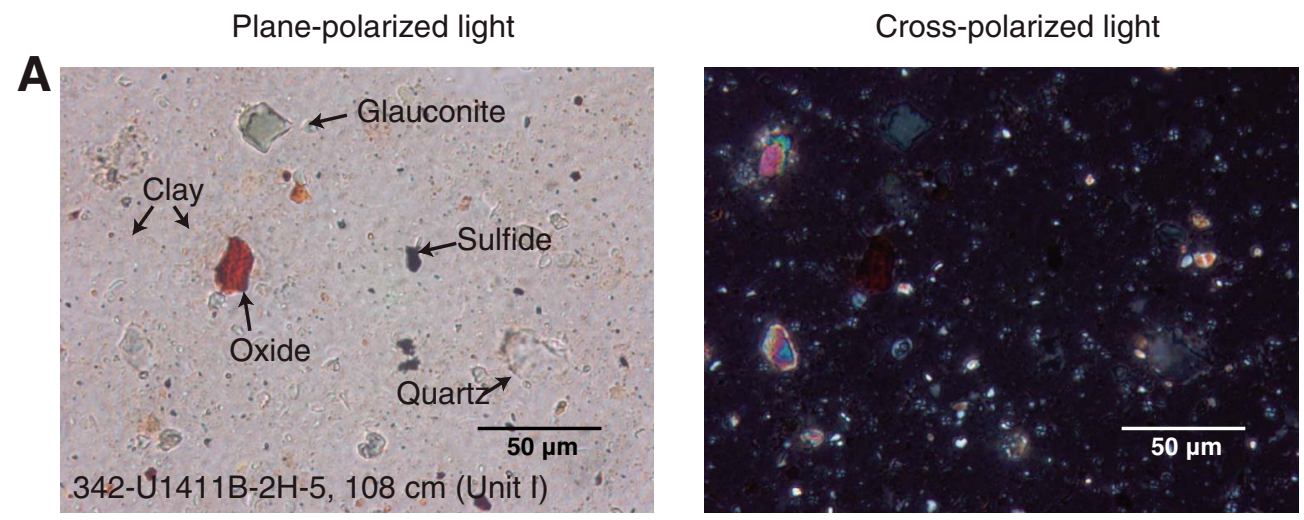

B

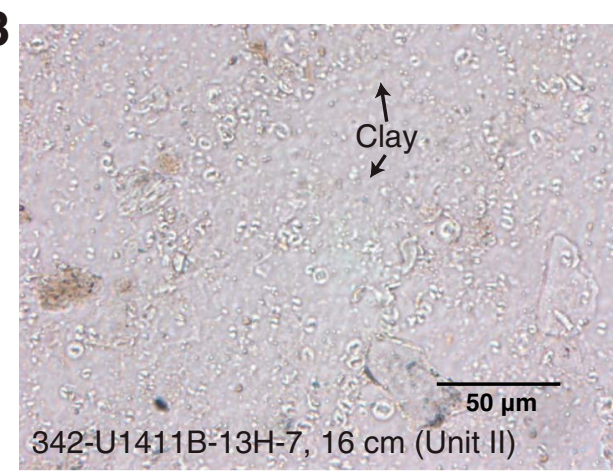

C

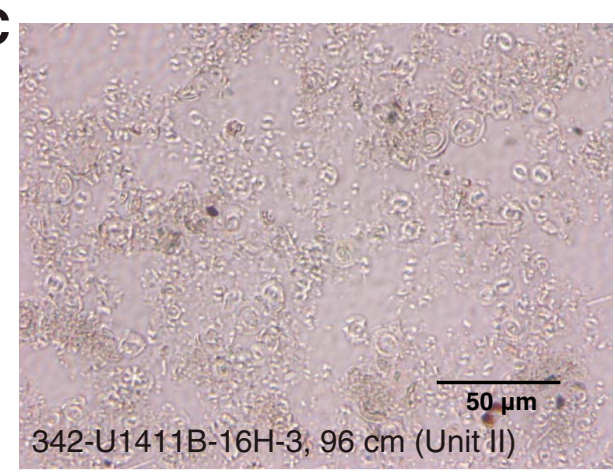

D

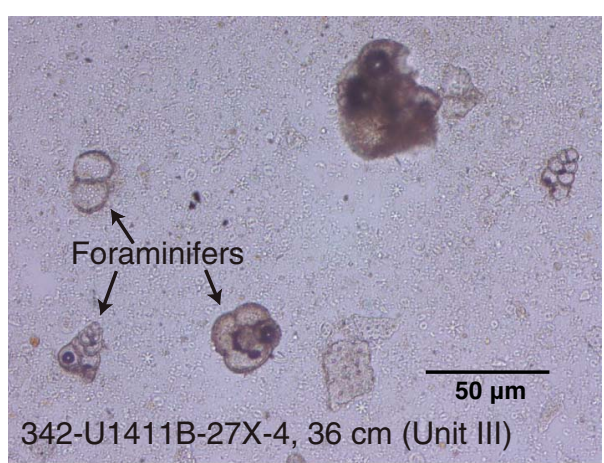

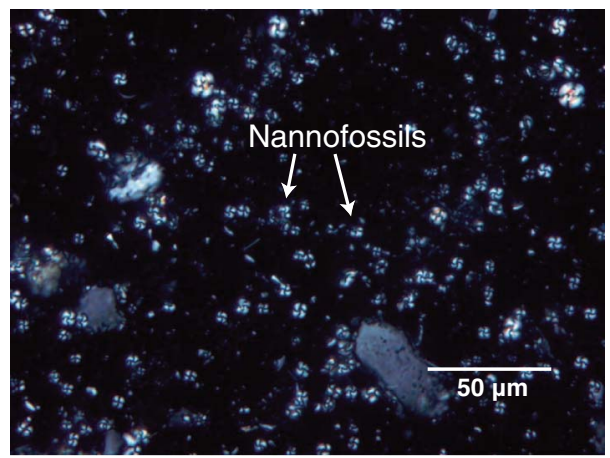
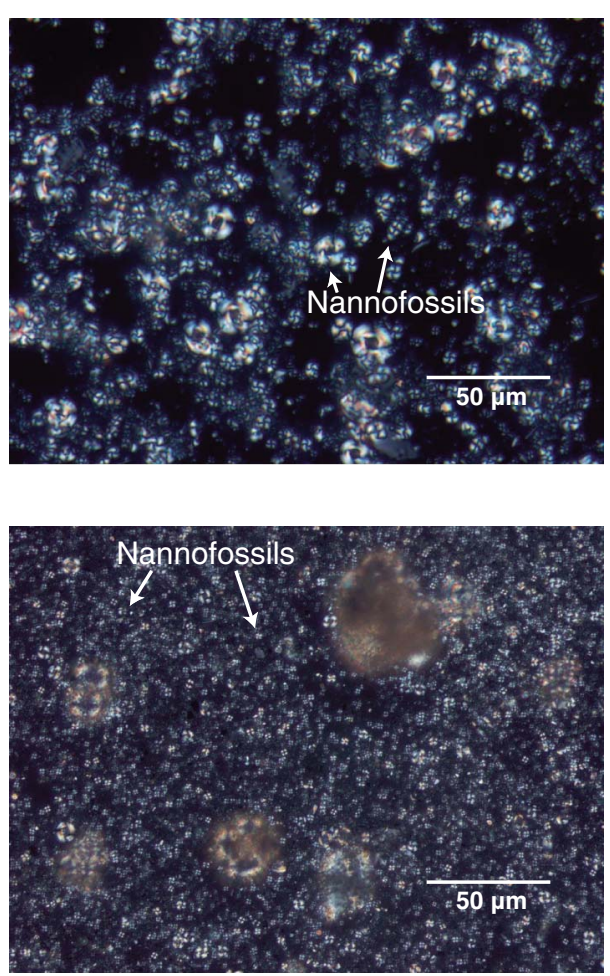
Figure F9. Smear slide results of major biogenic and lithologic components and their relative abundance, Hole U1411B. VA = very abundant, $\mathrm{A}=$ abundant, $\mathrm{C}=$ common, $\mathrm{F}=$ few, $\mathrm{P}=$ present.

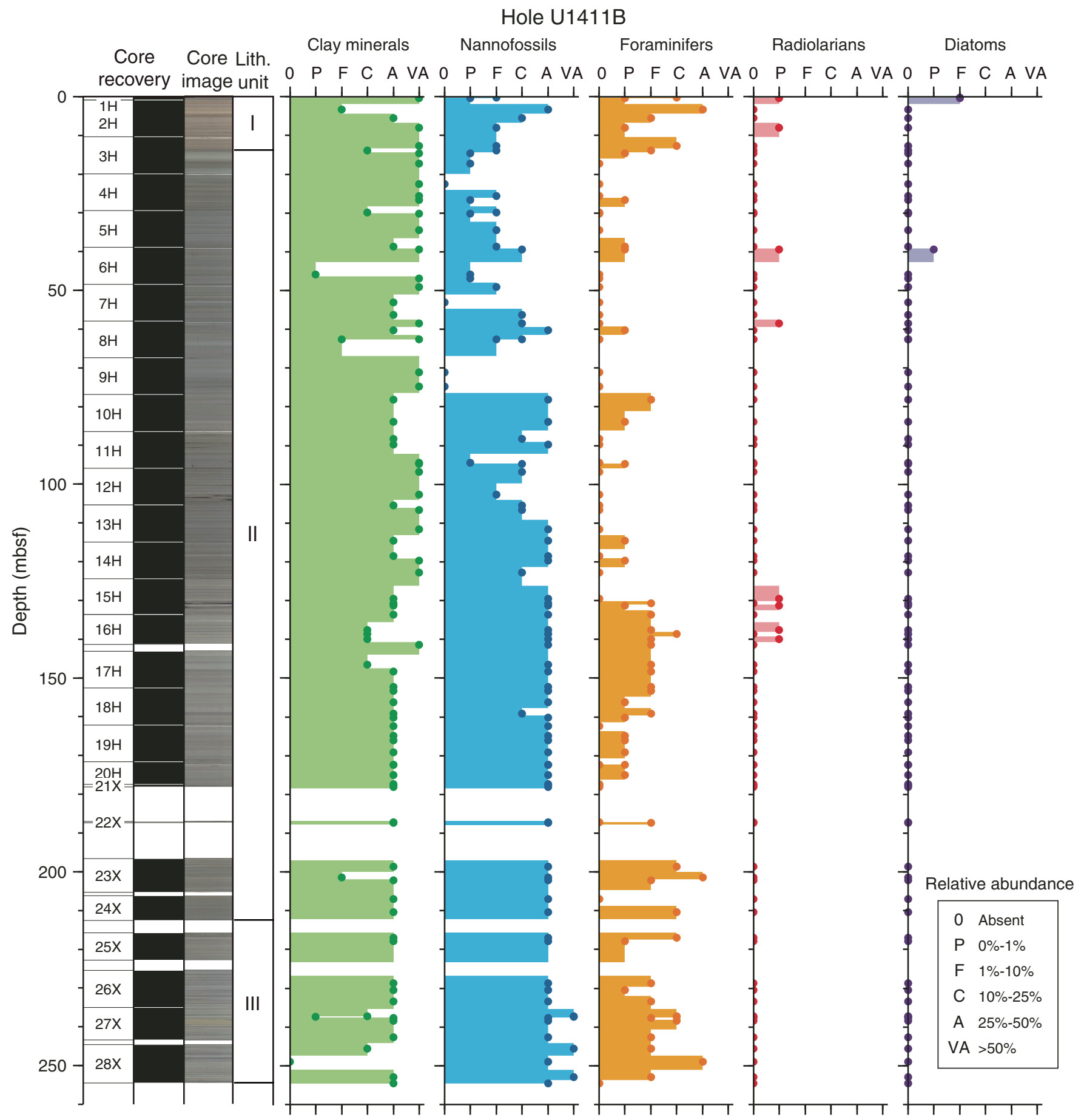


Figure F10. A. Image of coarse sand-sized rock fragment composed of a calcite-cemented, poorly lithified silty sandstone of angular, very fine quartz silt and sand. B. Image of bleb composed of angular, very fine quartz silt and sand. Matrix is dark greenish gray (10Y 4/1) clay with nannofossils.

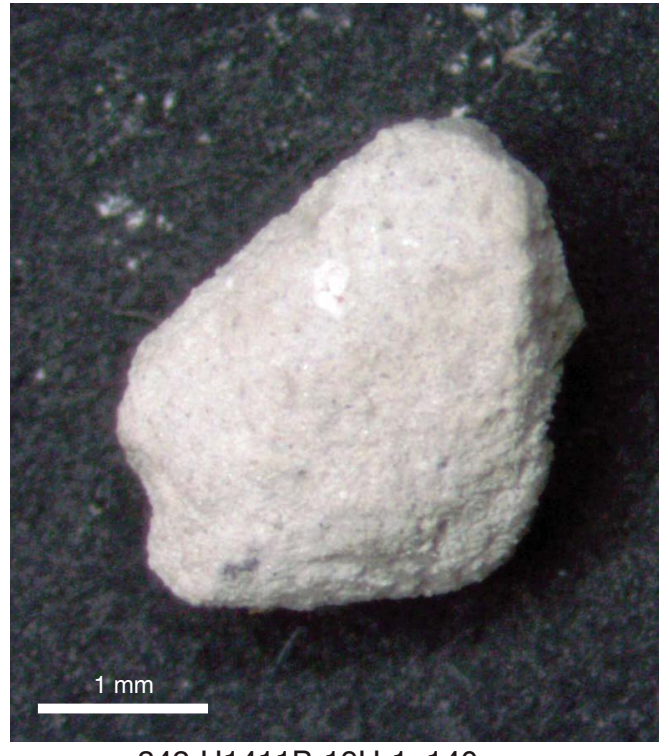

342-U1411B-19H-1, $140 \mathrm{~cm}$

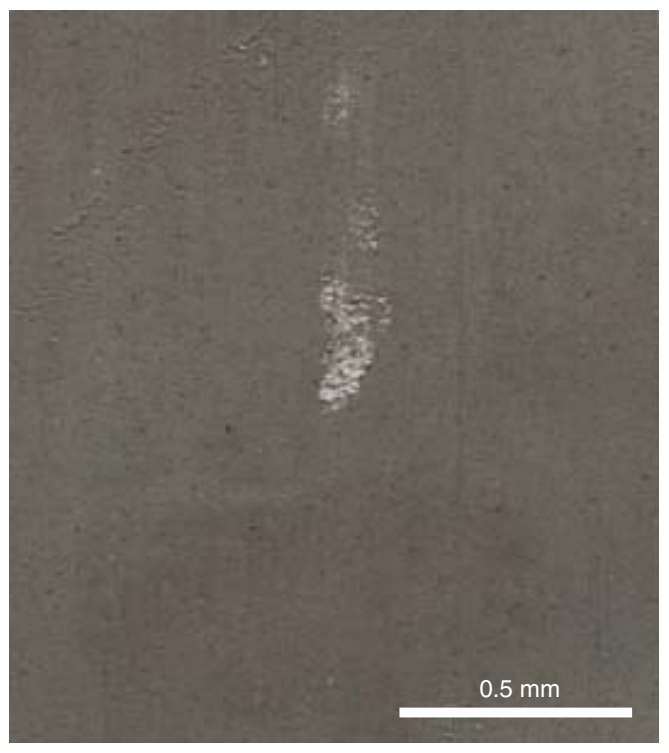

342-U1411B-11H-5, $92 \mathrm{~cm}$ 
Figure F11. Plots of lithology, natural gamma radiation (NGR), and carbonate content of the Eocene-Oligocene transition, Holes U1411B and U1411C. A minimum in color reflectance occurs just above the tentative Chron C13r/C13n boundary and coincides with a darker interval in Core 342-U1411B-17H. Lower NGR values in Cores $15 \mathrm{H}$ to $17 \mathrm{H}$ coincide with relatively carbonate rich intervals (see "Geochemistry").

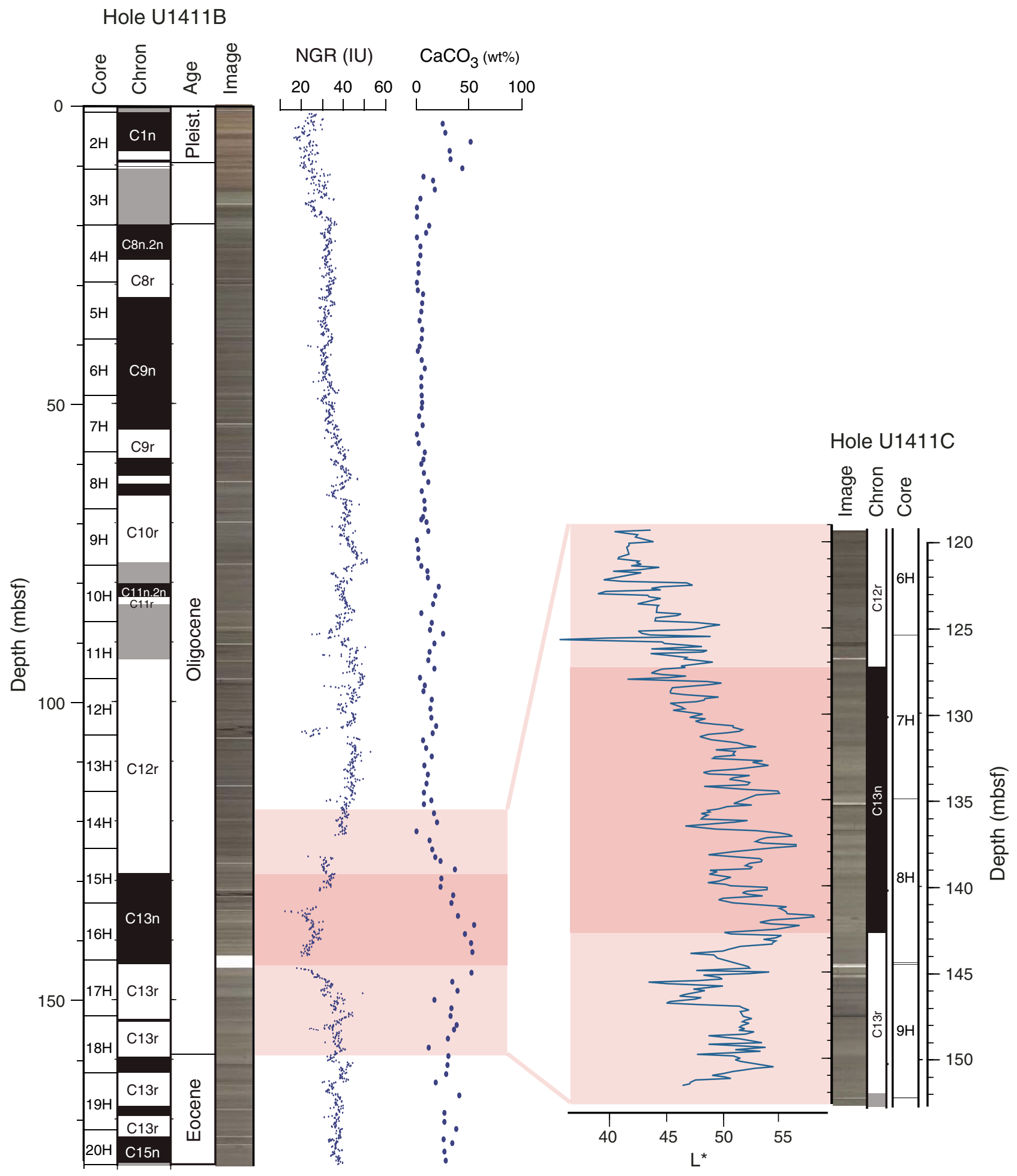


Figure F12. Integrated calcareous and siliceous microfossil biozonation, Site U1411.

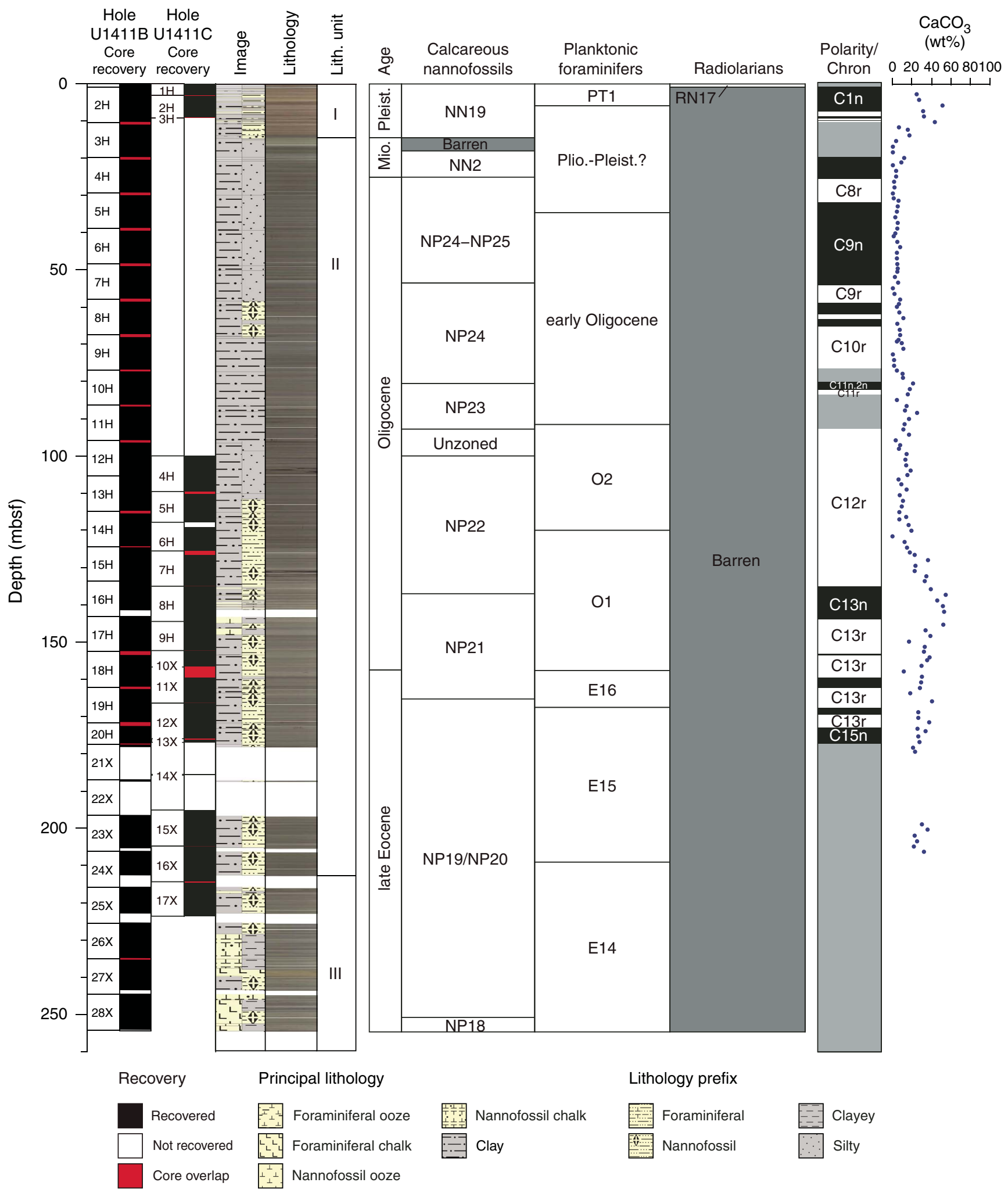


Figure F13. Group abundance and preservation of calcareous and siliceous microfossils, Site U1411. Solid symbols represent data from Hole U1411B. Abundance: $\mathrm{B}=$ barren, $\mathrm{P}=$ present, $\mathrm{R}=$ rare, $\mathrm{F}=$ few, $\mathrm{C}=$ common, $\mathrm{A}=$ abundant, $\mathrm{D}=$ dominant. Preservation: $\mathrm{P}=$ poor, $\mathrm{M}=$ moderate, $\mathrm{G}=$ good, $\mathrm{VG}=$ very good.
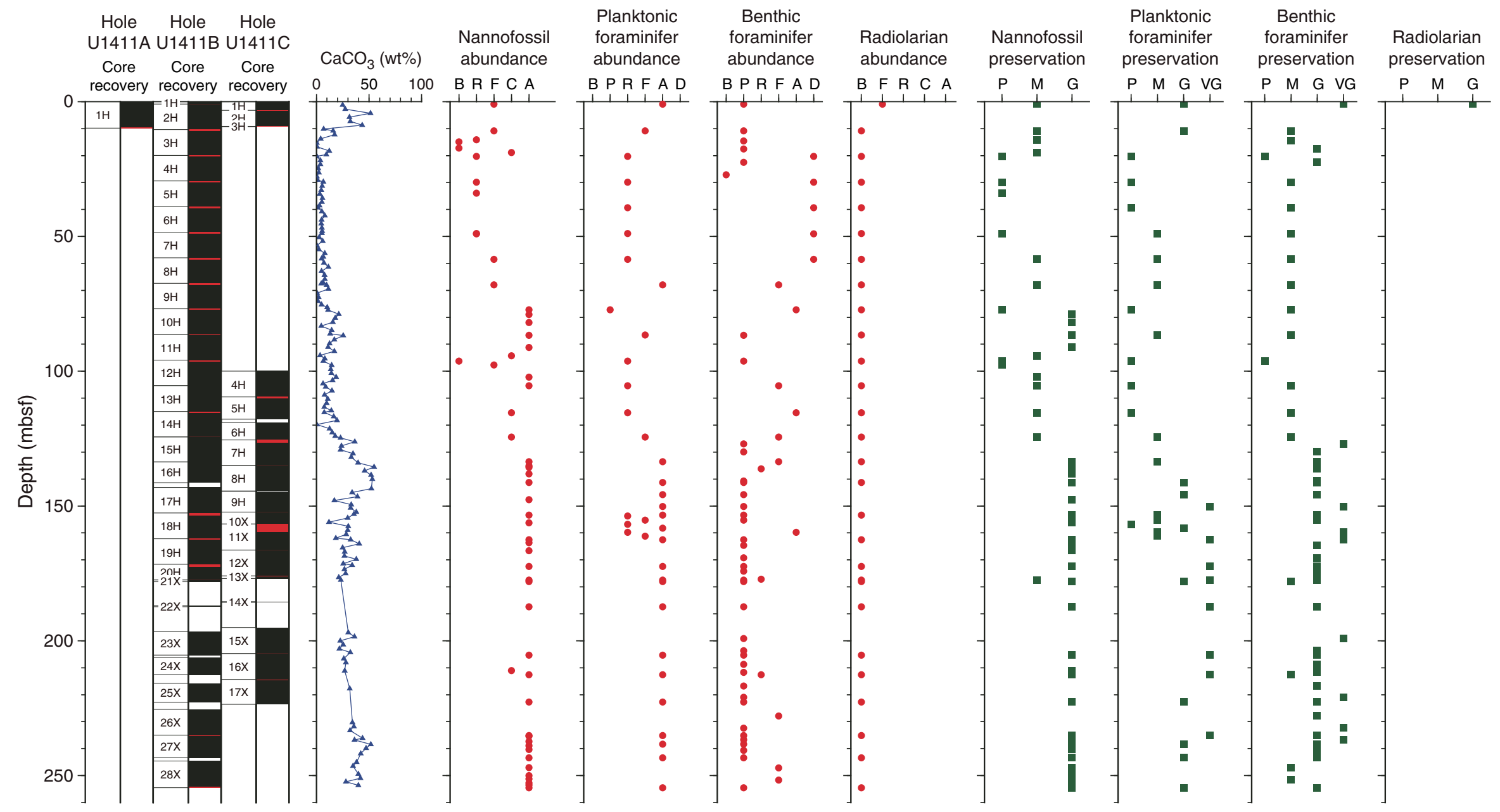
Figure F14. Plots of downhole variation of magnetic susceptibility and paleomagnetism data, Hole U1411B. Magnetization intensity, inclination, and declination are after $20 \mathrm{mT}$ demagnetization. Only oriented advanced piston corer (APC) intervals show directions in geographic coordinates. Directions from extended core barrel (XCB) intervals are shown in sample coordinates. For discrete sample data, if the samples were analyzed by principal component analysis (PCA; Kirschvink, 1980), then directions are shown according to PCA declination and inclination. Otherwise, directions following $20 \mathrm{mT}$ demagnetization are shown. Polarity: black $=$ normal chron, white $=$ reversed chron, gray $=$ unidentified interval .

Hole U1411B

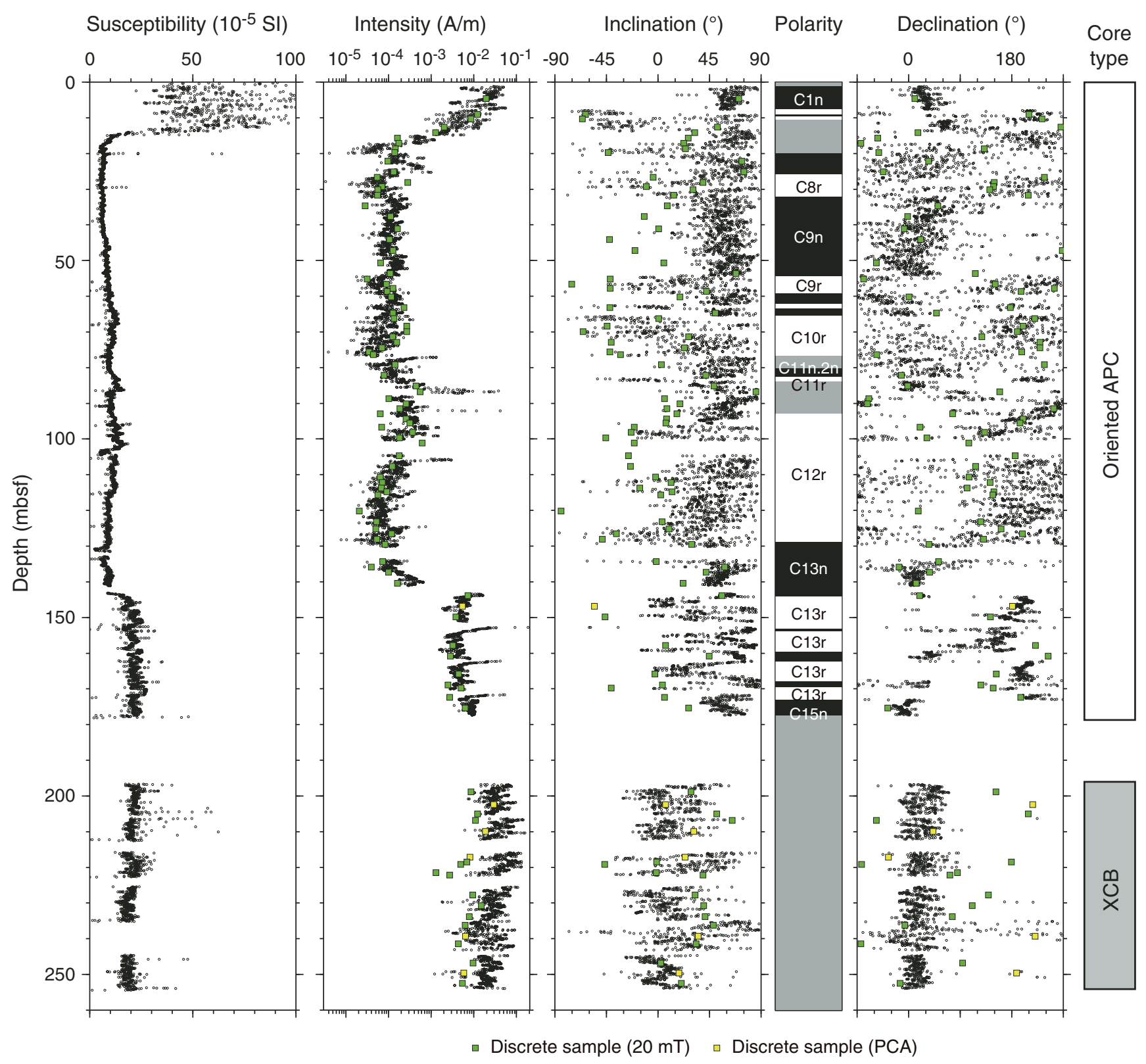


Figure F15. Plots of downhole variation of magnetic susceptibility and paleomagnetism data, Hole U1411C. Magnetization intensity, inclination, and declination are after $20 \mathrm{mT}$ demagnetization. Directions are shown in geographic coordinates for the oriented advanced piston corer (APC) intervals. XCB = extended core barrel. Polarity: black $=$ normal chron, white $=$ reversed chron, gray $=$ unidentified interval .

Hole U1411C

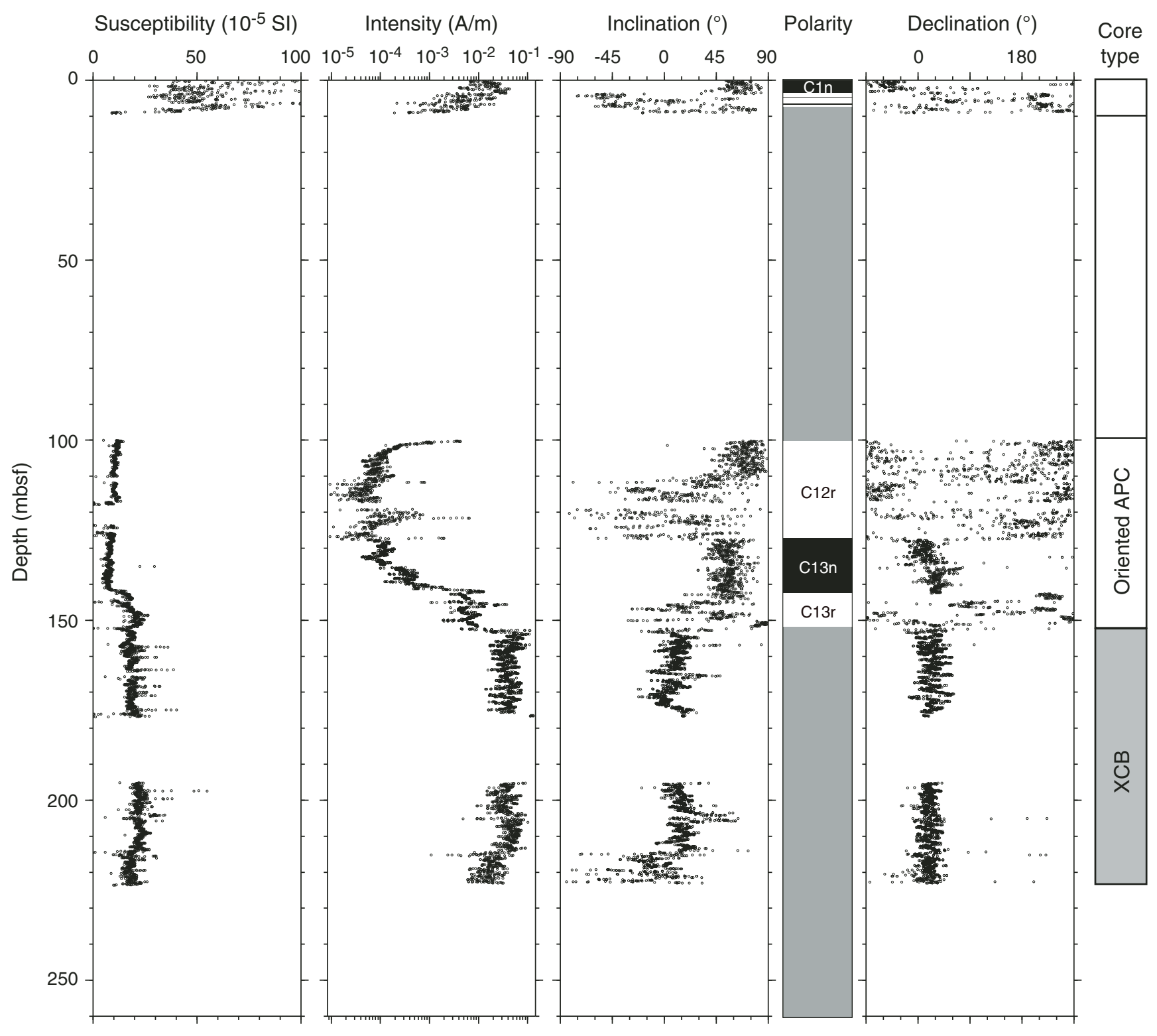


Figure F16. Plots of representative alternating field (AF) demagnetization results for discrete paleomagnetism samples, Site U1411. Upper plots show intensity variation with progressive demagnetization, and lower plots show vector endpoints of paleomagnetism directions on orthogonal vector diagrams (i.e., Zijderveld plots). Vector diagrams indicate reasonably resolved characteristic remanent magnetization (ChRM) direction from the (A) APC core intervals, whereas (B) other samples from the APC core intervals do not show a stable component. Solid circles $=$ horizontal projections, open circles $=$ vertical projections, gray circles $=$ data not used to calculate ChRM direction, black dashed line $=$ ChRM direction. Inc $=$ inclination, Dec $=$ declination, $\mathrm{MAD}=$ maximum angle of deviation .
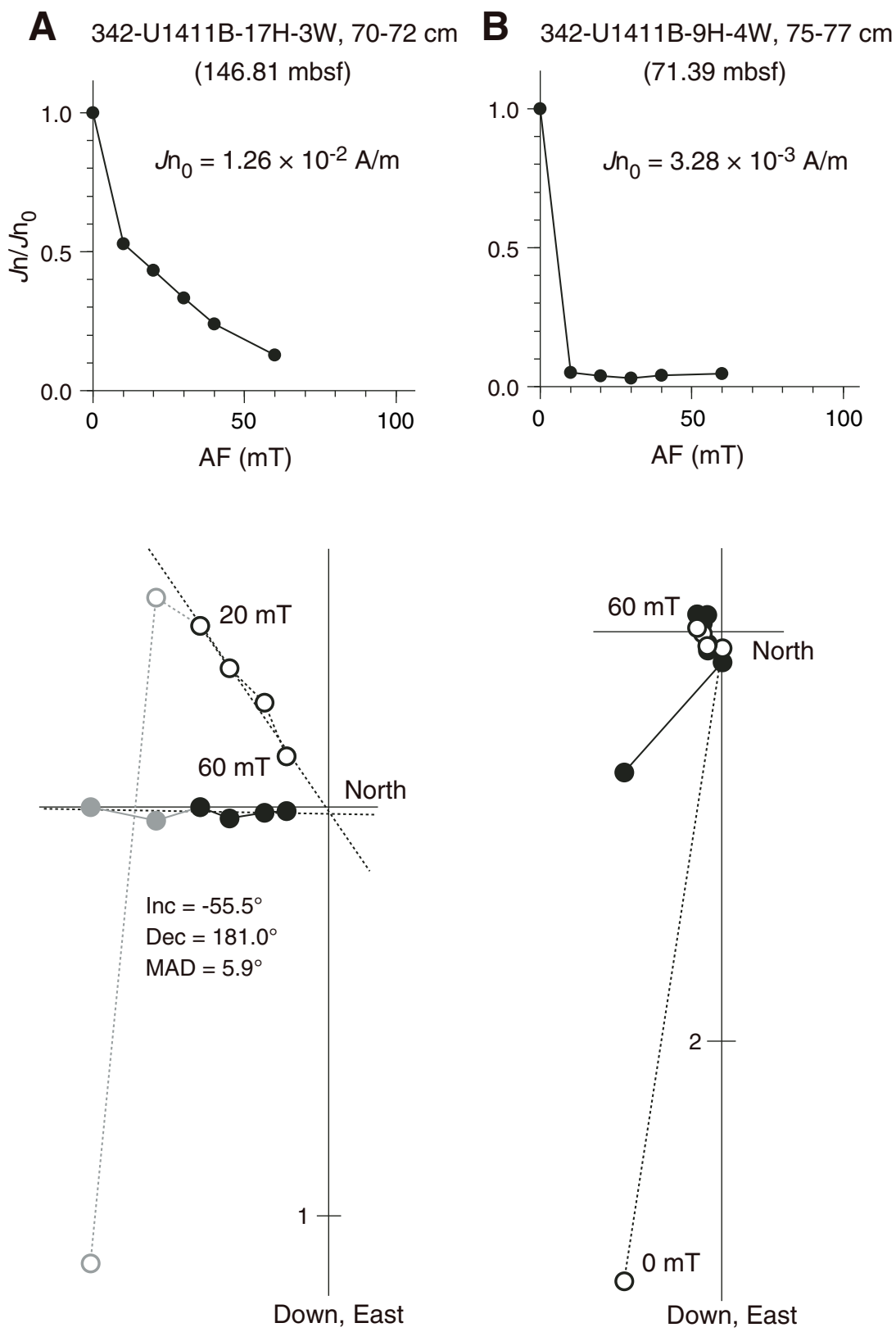

Down, East 
Figure F17. Illustration of magnetostratigraphy, Site U1411. Core recovery: black $=$ recovered, white $=$ not recovered, red = core overlap.

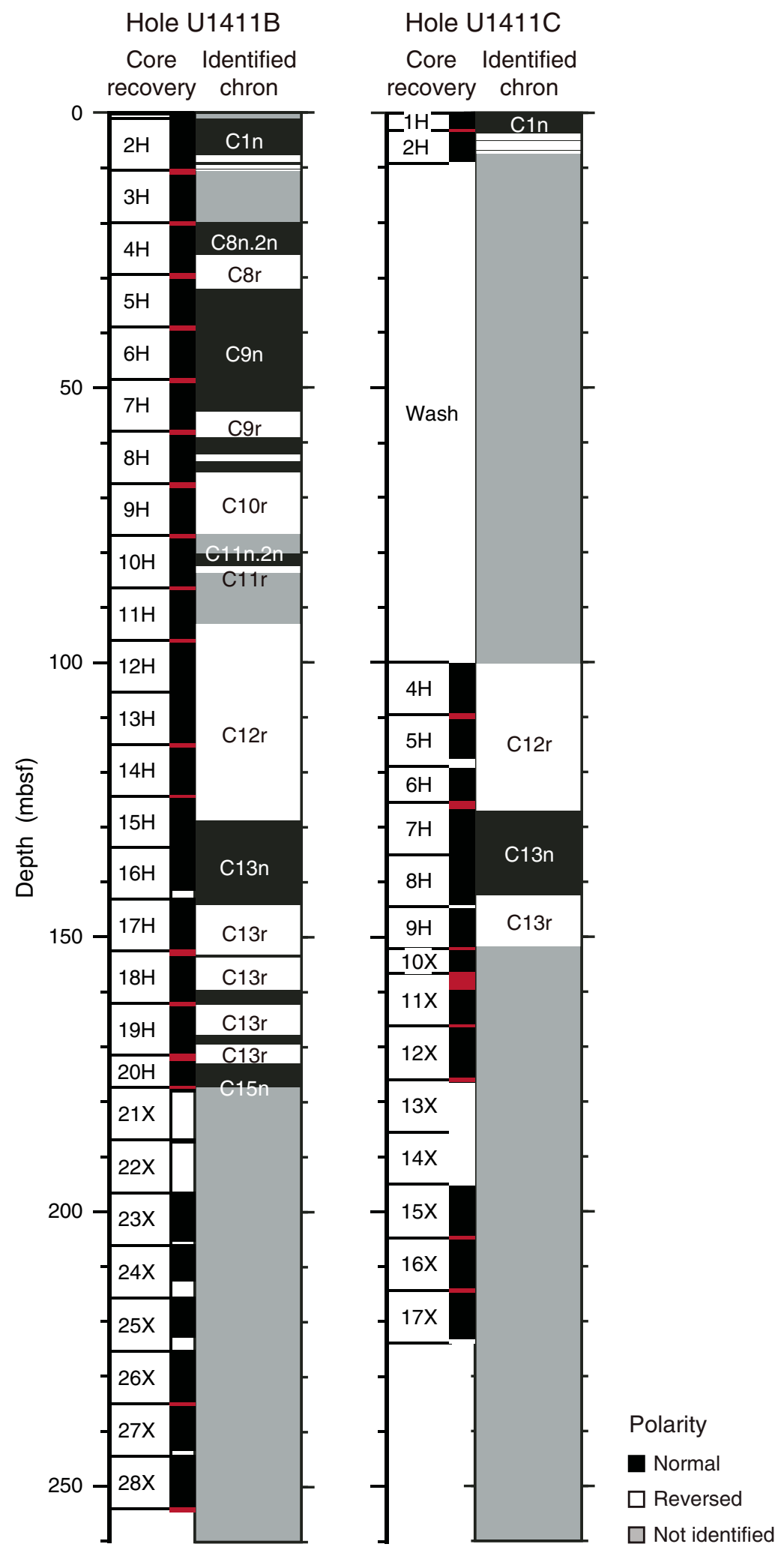


Figure F18. Plots of downhole variation of paleomagnetism data after $20 \mathrm{mT}$ demagnetization for Core 342 U1411B-17H showing the Chron C13n/C13r boundary. Directions are shown in geographic coordinates. For discrete sample data, intensity and directions are after $20 \mathrm{mT}$ demagnetization. Blue lines = section breaks. Polarity: black $=$ normal chron, white $=$ reversed chron PCA $=$ principal component analysis.
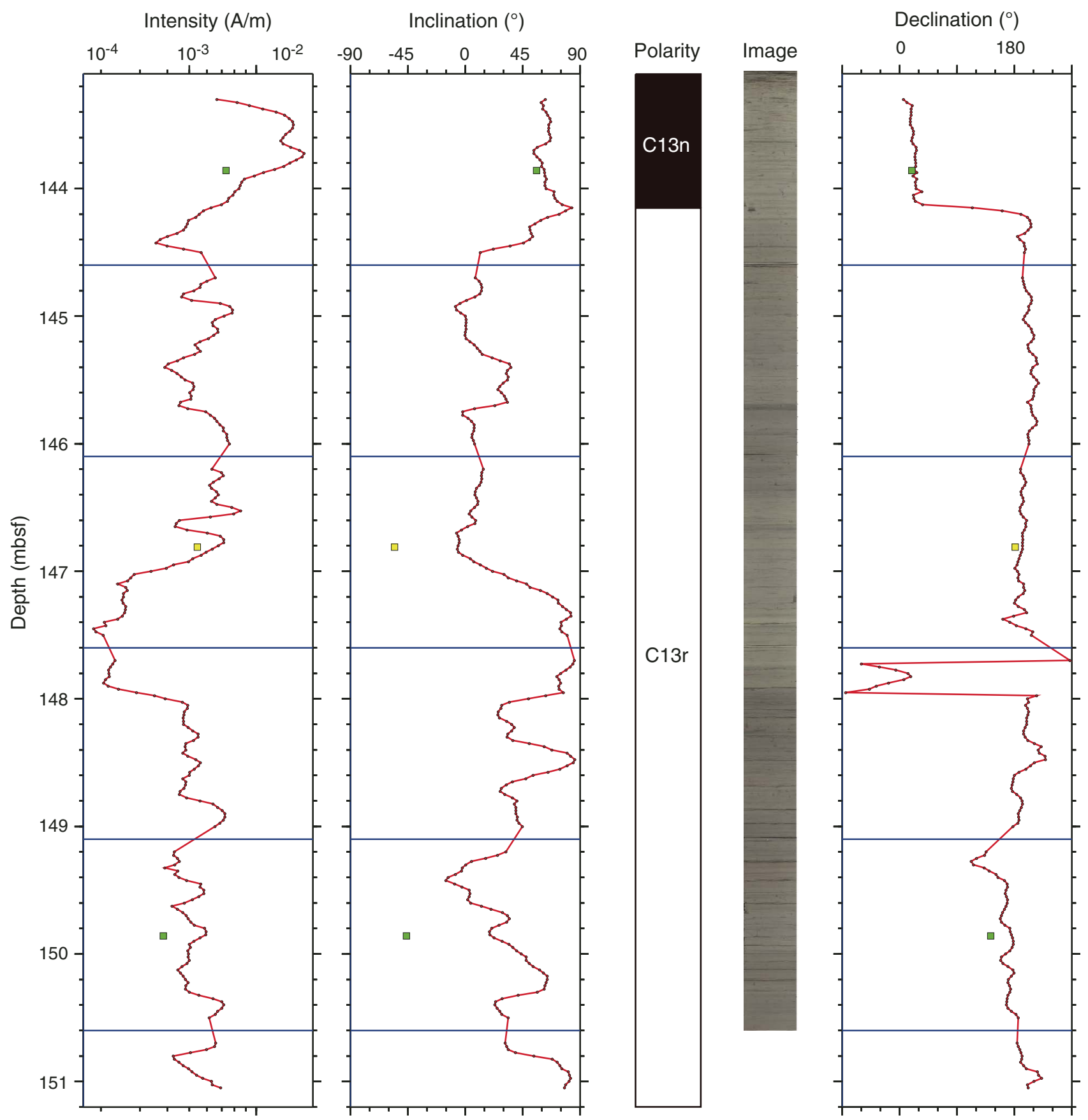

- Discrete sample (20 mT)

$\square$ Discrete sample (PCA) 
Figure F19. Age-depth model for Hole U1411A showing biostratigraphic and magnetostratigraphic datums. Also shown are estimated linear sedimentation rates for line segments based on the datums listed in Table T13.

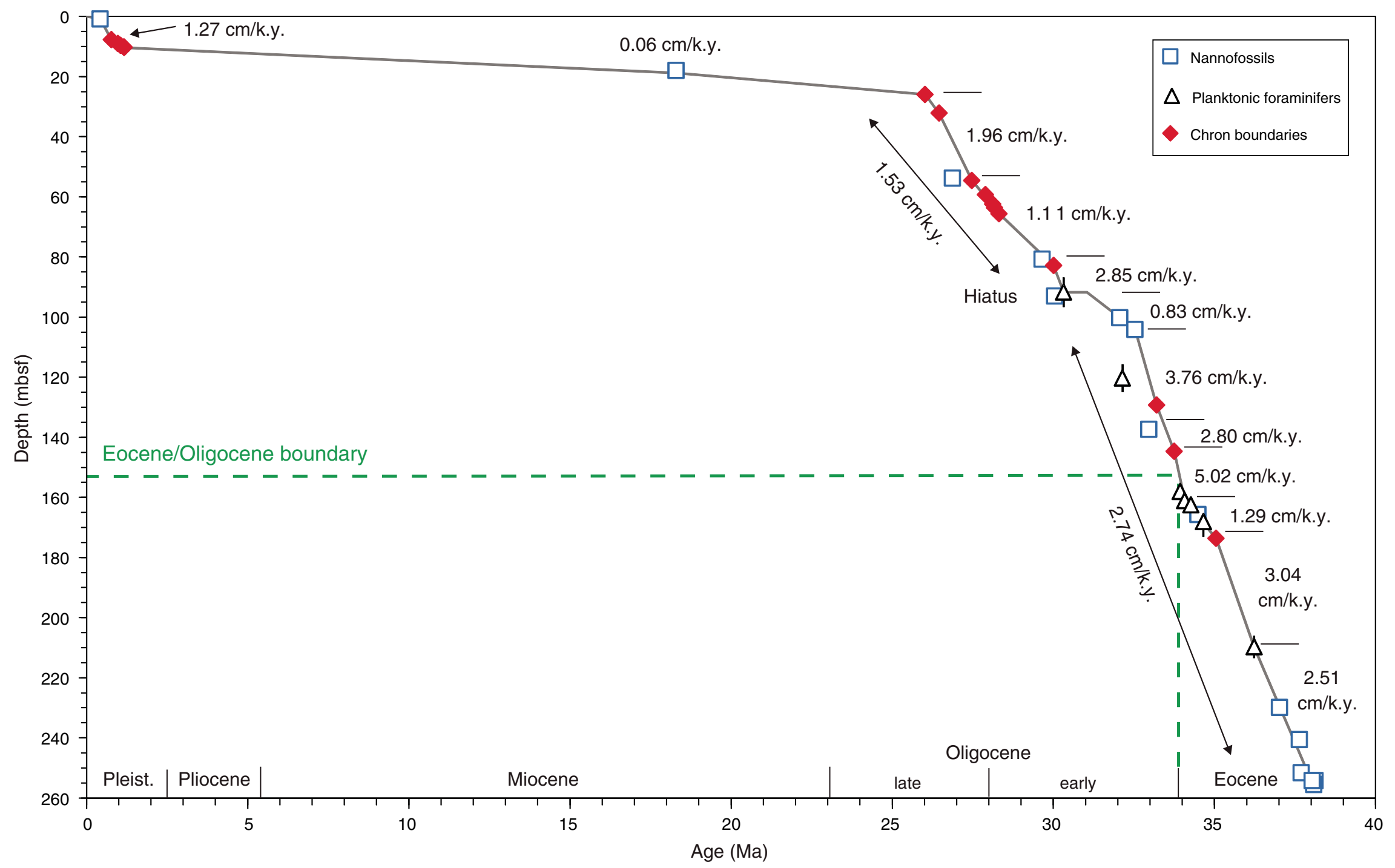


Figure F20. Linear sedimentation rate (LSR), dry bulk density (DBD), carbonate content, and mass accumulation rate (MAR) for carbonate and noncarbonate components at a time step of 200 k.y., Hole U1411A. Filled black diamonds show the inflection points in estimated LSR, DBD, and carbonate content. Geologic ages are shown on the GTS2012 timescale (Gradstein et al., 2012). CAR = carbonate mass accumulation rate, $\mathrm{nCAR}=$ noncarbonate mass accumulation rate.
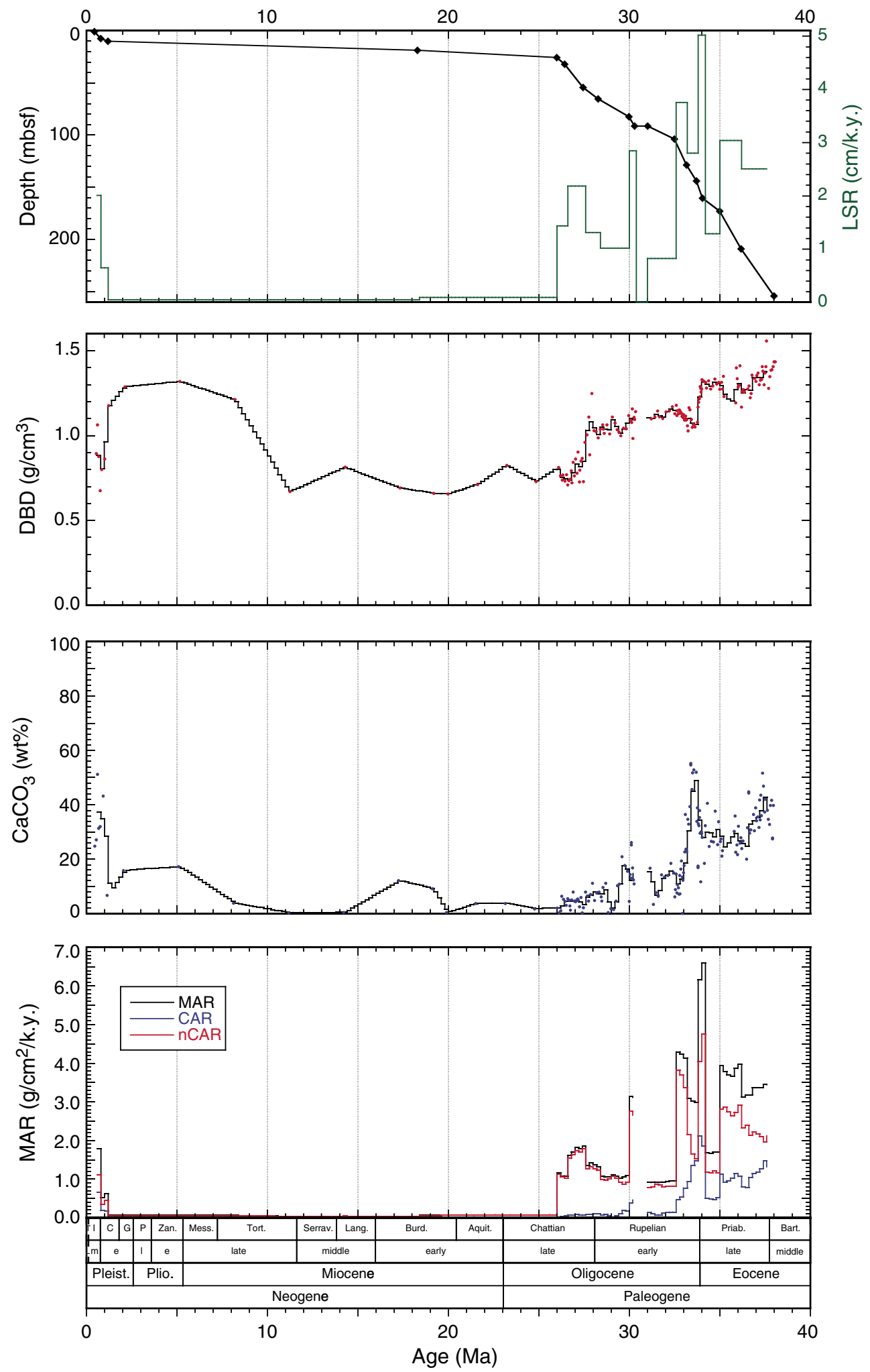
Figure F21. Plots of interstitial water constituent concentrations, Hole U1411B.
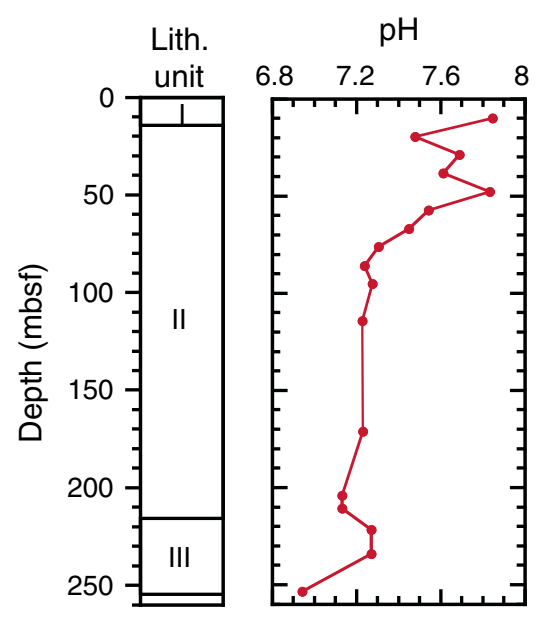

Alkalinity (mM)

Salinity

Sodium (mM) Chloride $(\mathrm{mM})$
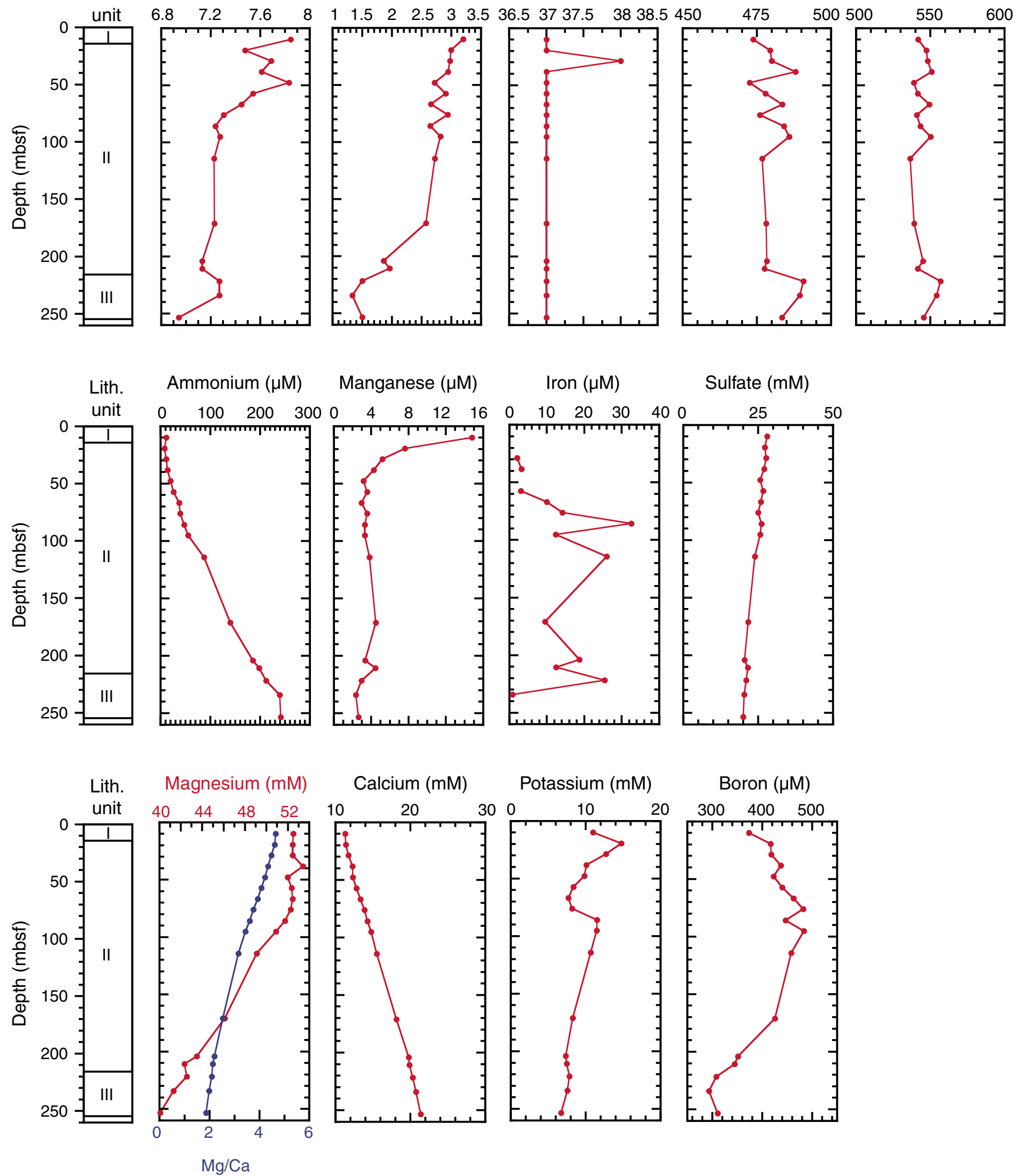
Figure F22. Plot of sedimentary carbonate content, Hole U1411B. TOC = total organic carbon.

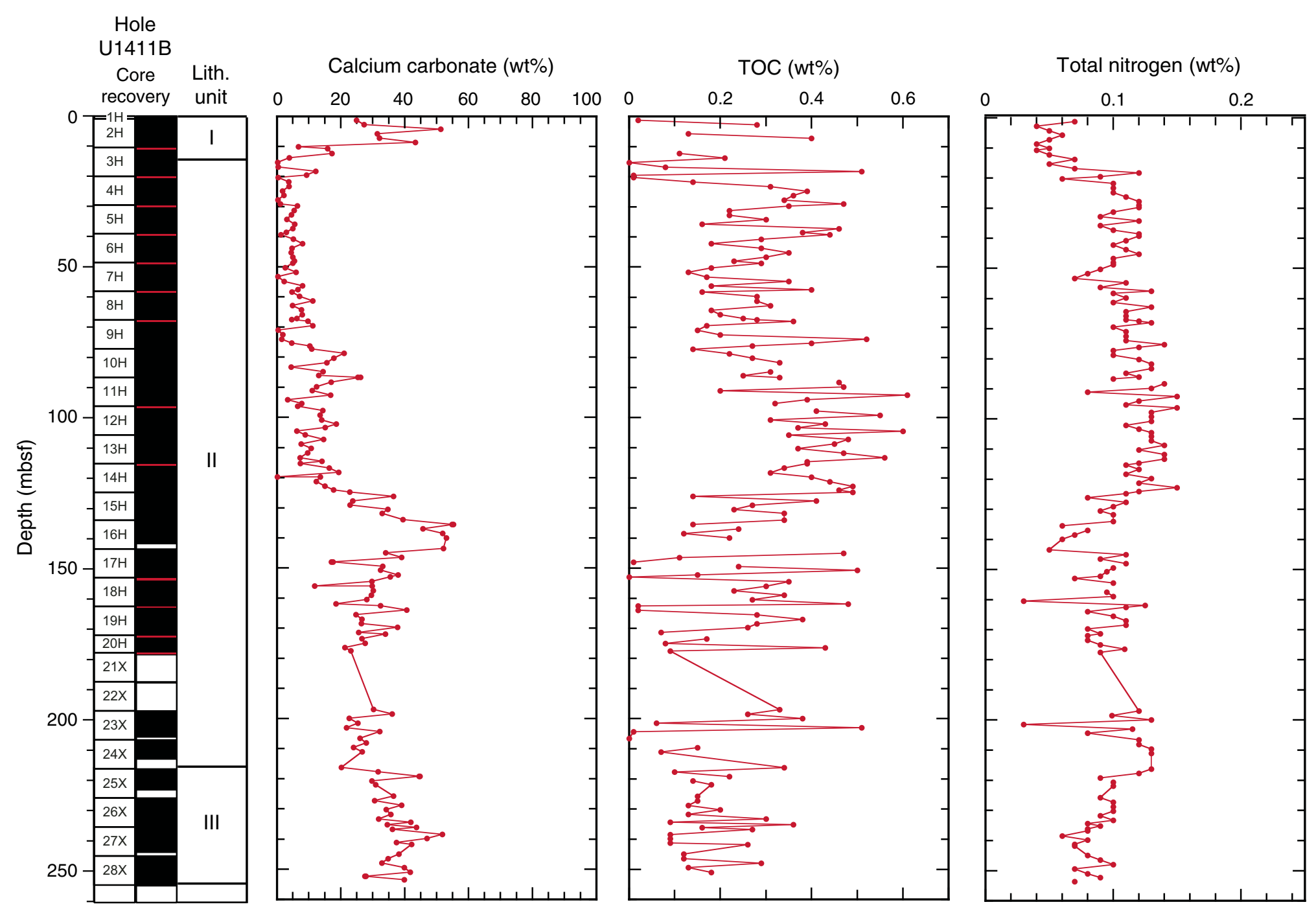


Figure F23. Plots of magnetic susceptibility (MS), bulk density, porosity, water content, and grain density, Site U1411. Data in green is from Hole U1411A. Core recovery: black $=$ recovered, white $=$ not recovered, red $=$ core overlap. Bulk density: gray line = gamma ray attenuation bulk density from Whole-Round Multisensor Logger data, black circles $=$ moisture and density bulk density from discrete samples. Horizontal gray lines indicate lithostratigraphic unit boundaries (see "Lithostratigraphy"). APC = advanced piston corer, DI = drilled interval, $\mathrm{XCB}=$ extended core barrel.
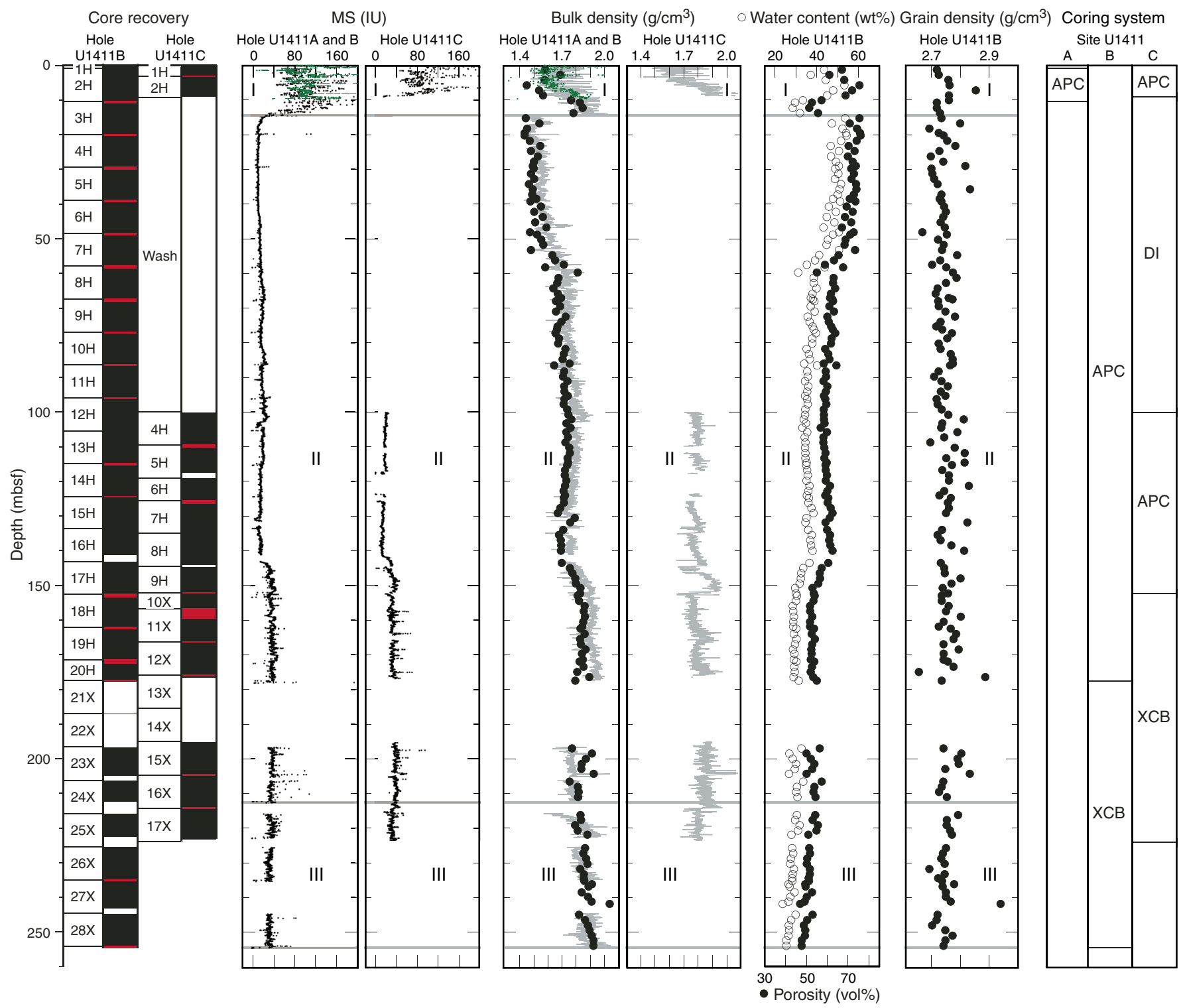
Figure F24. Plots of magnetic susceptibility (MS), $P$-wave velocity (gray line $=P$-wave logger data from wholeround sections, black circles $=P$-wave caliper probe data from section halves, green circles $=$ data from Hole U1411A), and natural gamma radiation (NGR), Site U1411. Core recovery: black = recovered, white $=$ not recovered, red = core overlap. Horizontal gray lines indicate lithostratigraphic unit boundaries (see "Lithostratigraphy"). APC = advanced piston corer, DI = drilled interval, XCB = extended core barrel.
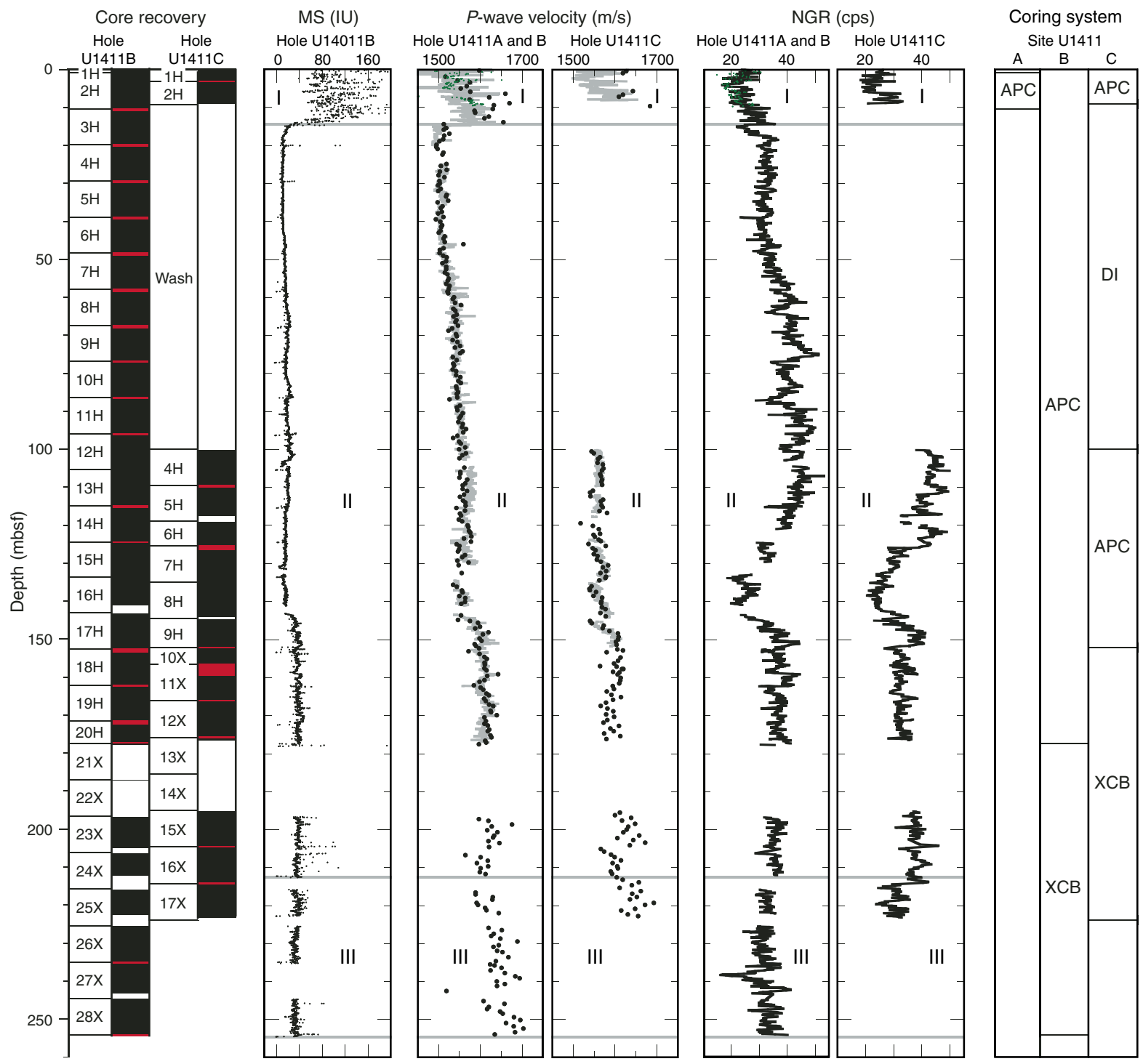
Figure F25. Plots of magnetic susceptibility (MS) and color reflectance $\left(a^{*}, b^{*}\right.$, and $\left.L^{*}\right)$, Site U1411. Data in green are from Hole U1411A. Core recovery: black $=$ recovered, white $=$ not recovered, red $=$ core overlap. Horizontal gray lines indicate lithostratigraphic unit boundaries (see "Lithostratigraphy"). APC = advanced piston corer, $\mathrm{DI}=$ drilled interval, $\mathrm{XCB}=$ extended core barrel.
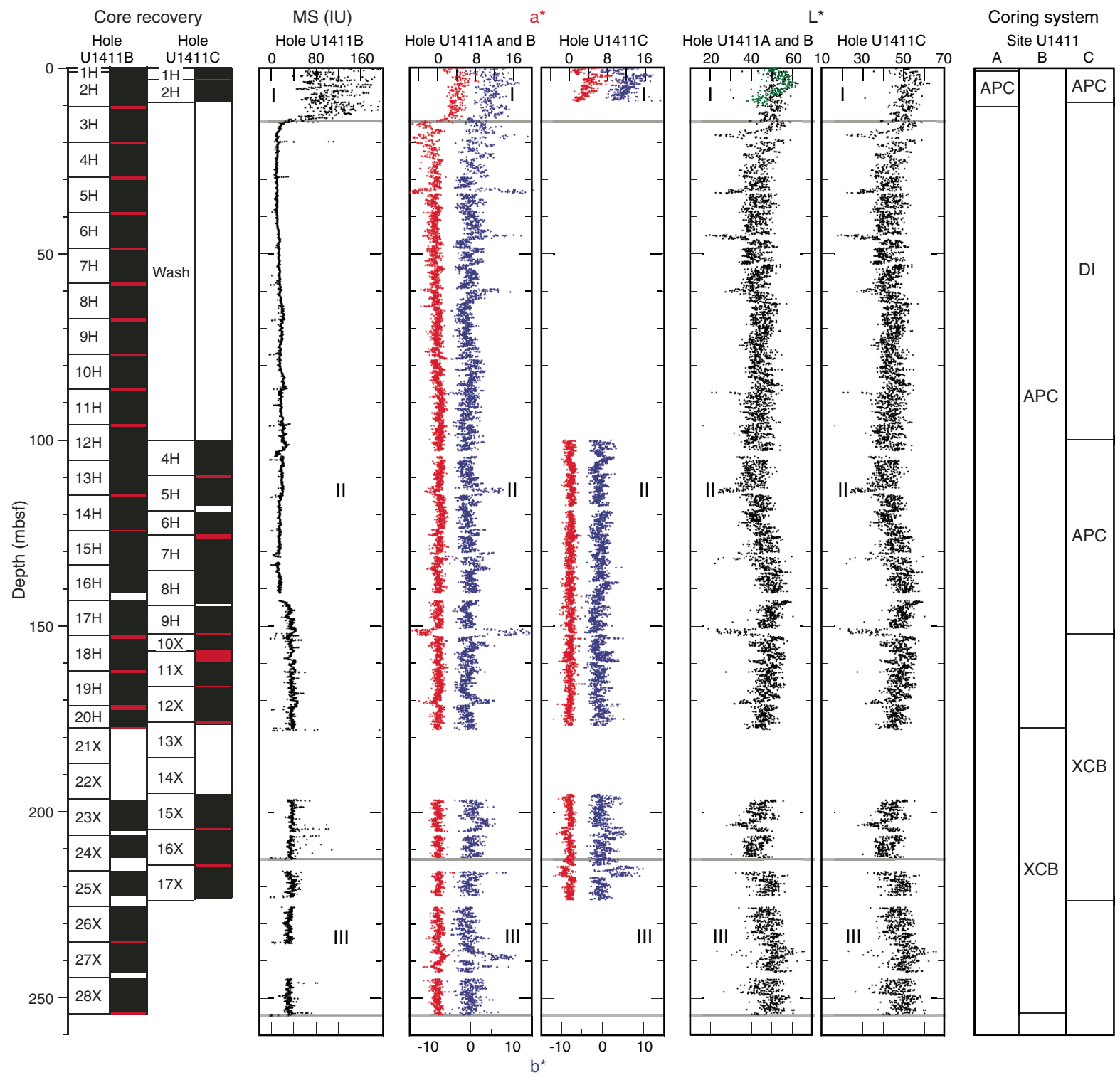
Figure F26. Plot of thermal conductivity measurements, Hole U1411B. Core recovery: black = recovered, white $=$ not recovered, red = core overlap. Blue line is the smooth-curve fit for the data set. Horizontal gray lines indicate lithostratigraphic unit boundaries (see "Lithostratigraphy").

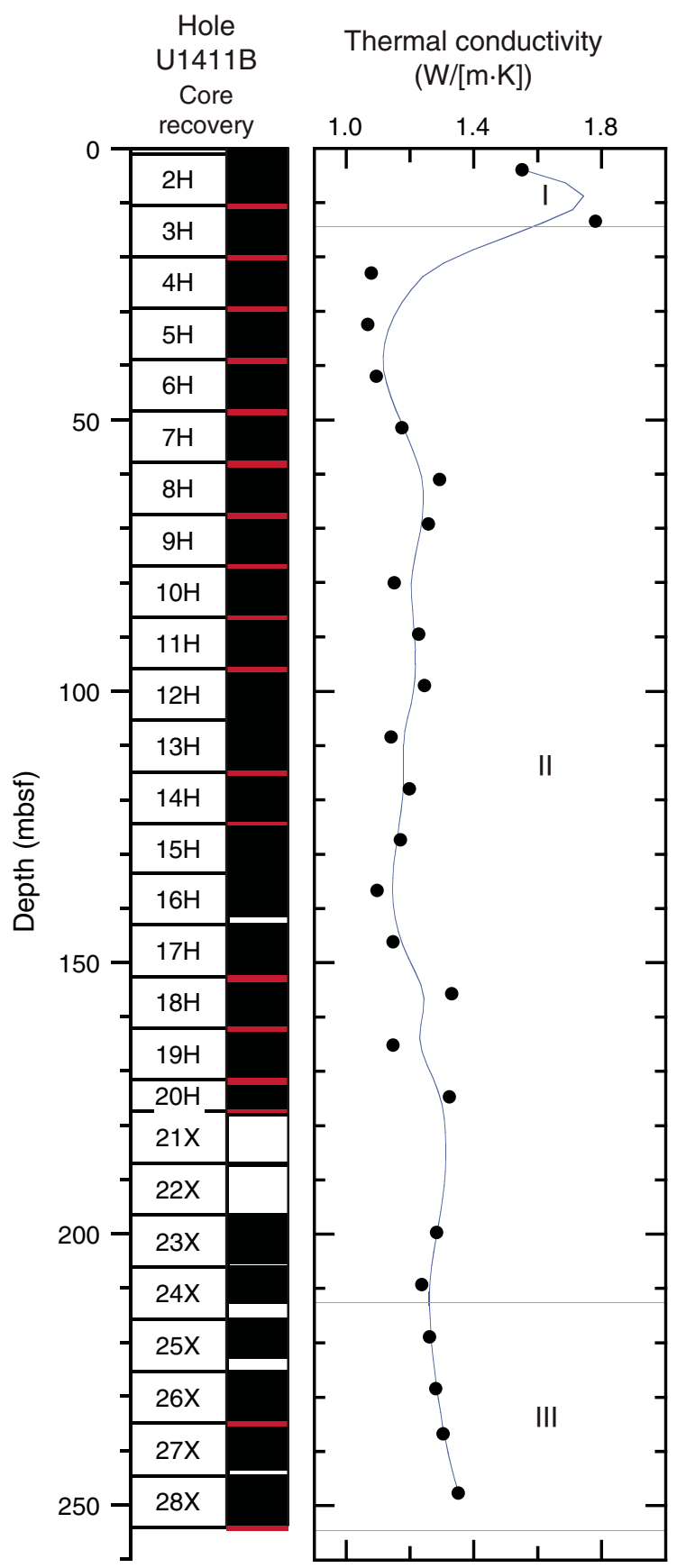


Figure F27. Plots of magnetic susceptibility data, Site U1411. Top panels show the spliced section for each interval of the splice. Bottom panels show complete magnetic susceptibility records. Data from Hole U1411C is offset by $20 \mathrm{IU}$ to aid visualization, except for A, in which data from Holes U1411A and U1411C are offset by 100 and 200, respectively. Open circles indicate core tops. A. 0-50 m CCSF. (Continued on next five pages.)
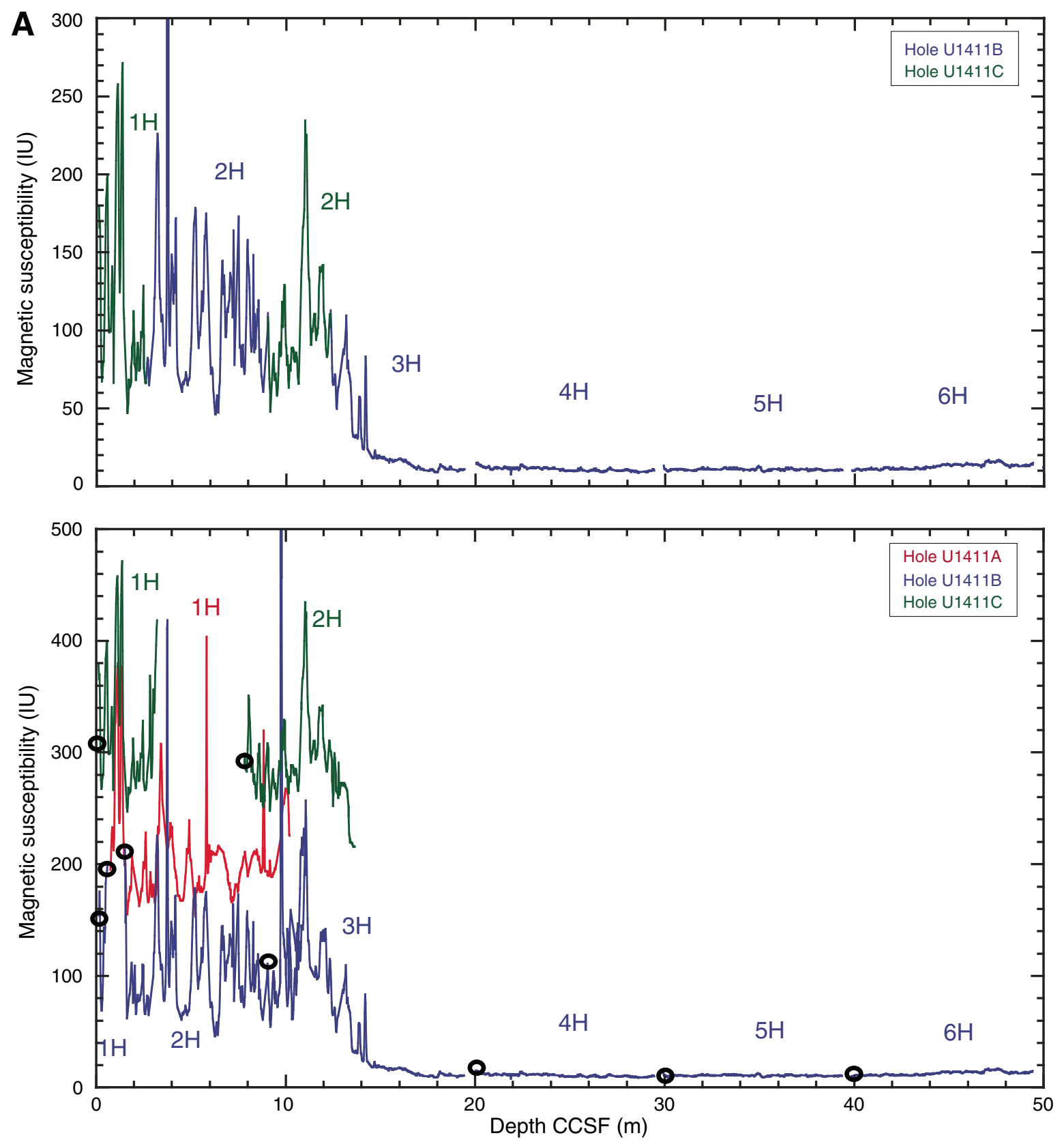
Figure F27 (continued). B. 50-100 m CCSF. (Continued on next page.)

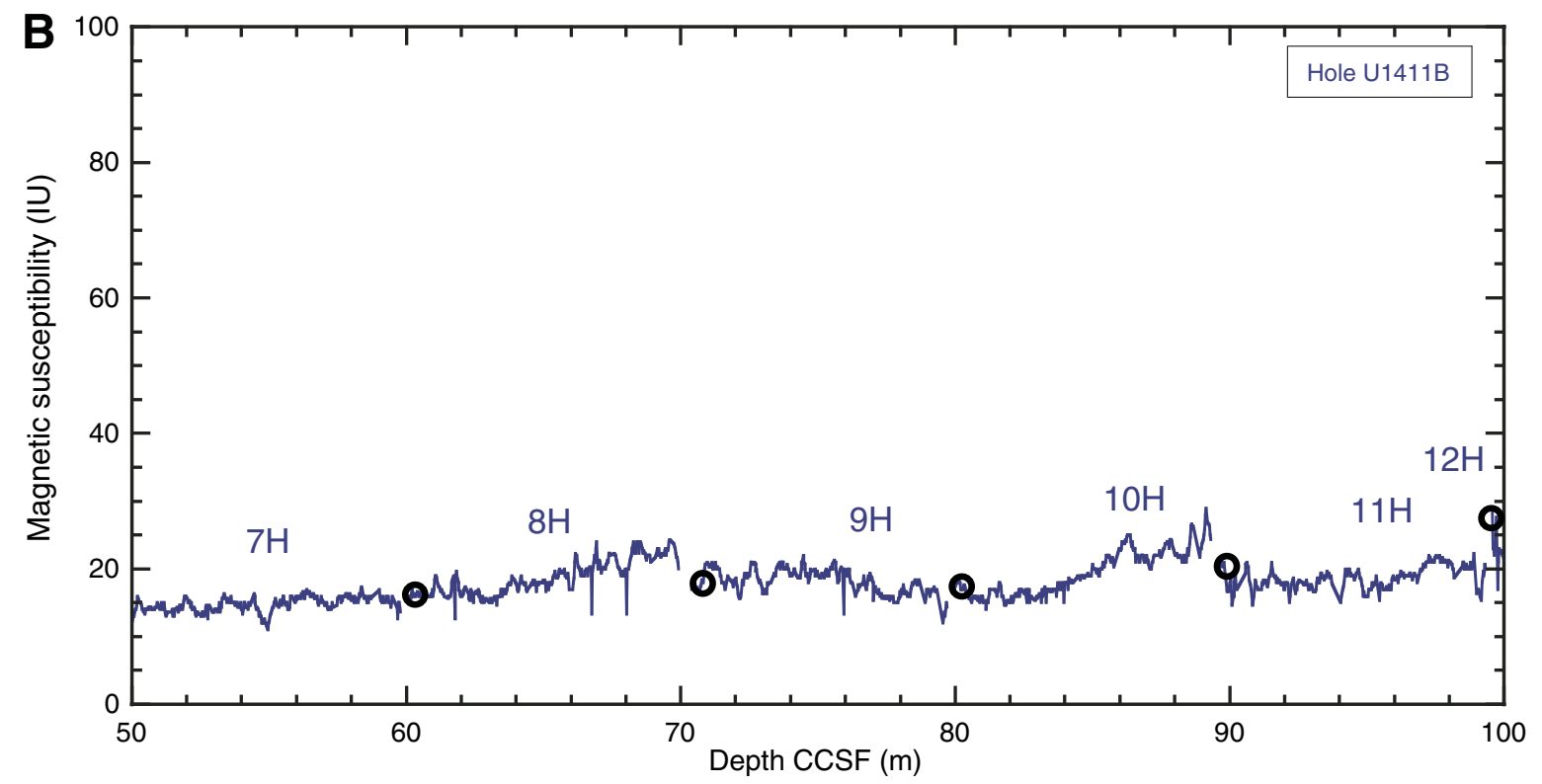


Figure F27 (continued). C. 100-150 m CCSF. (Continued on next page.)
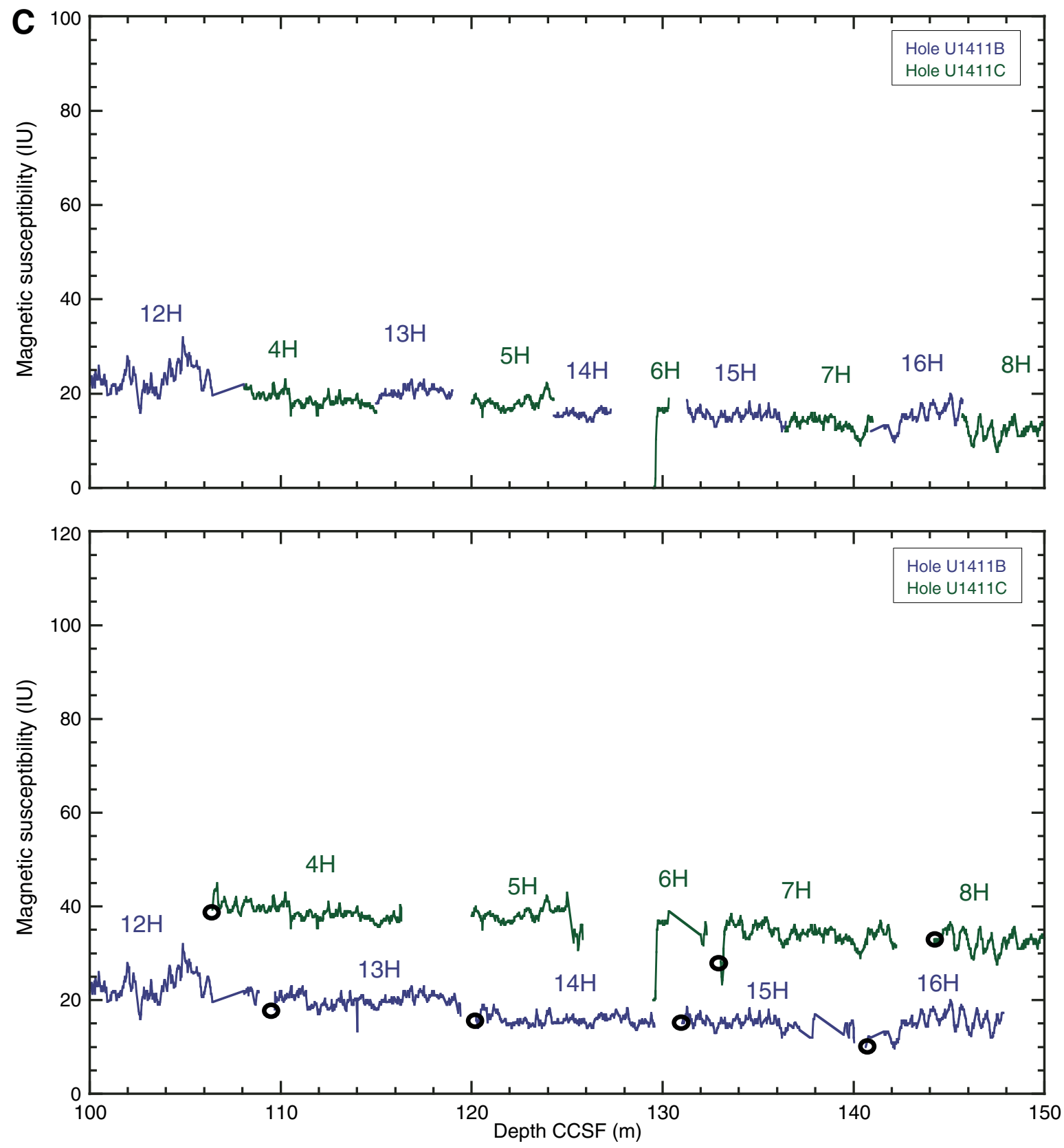
Figure F27 (continued). D. 150-200 m CCSF. (Continued on next page.)
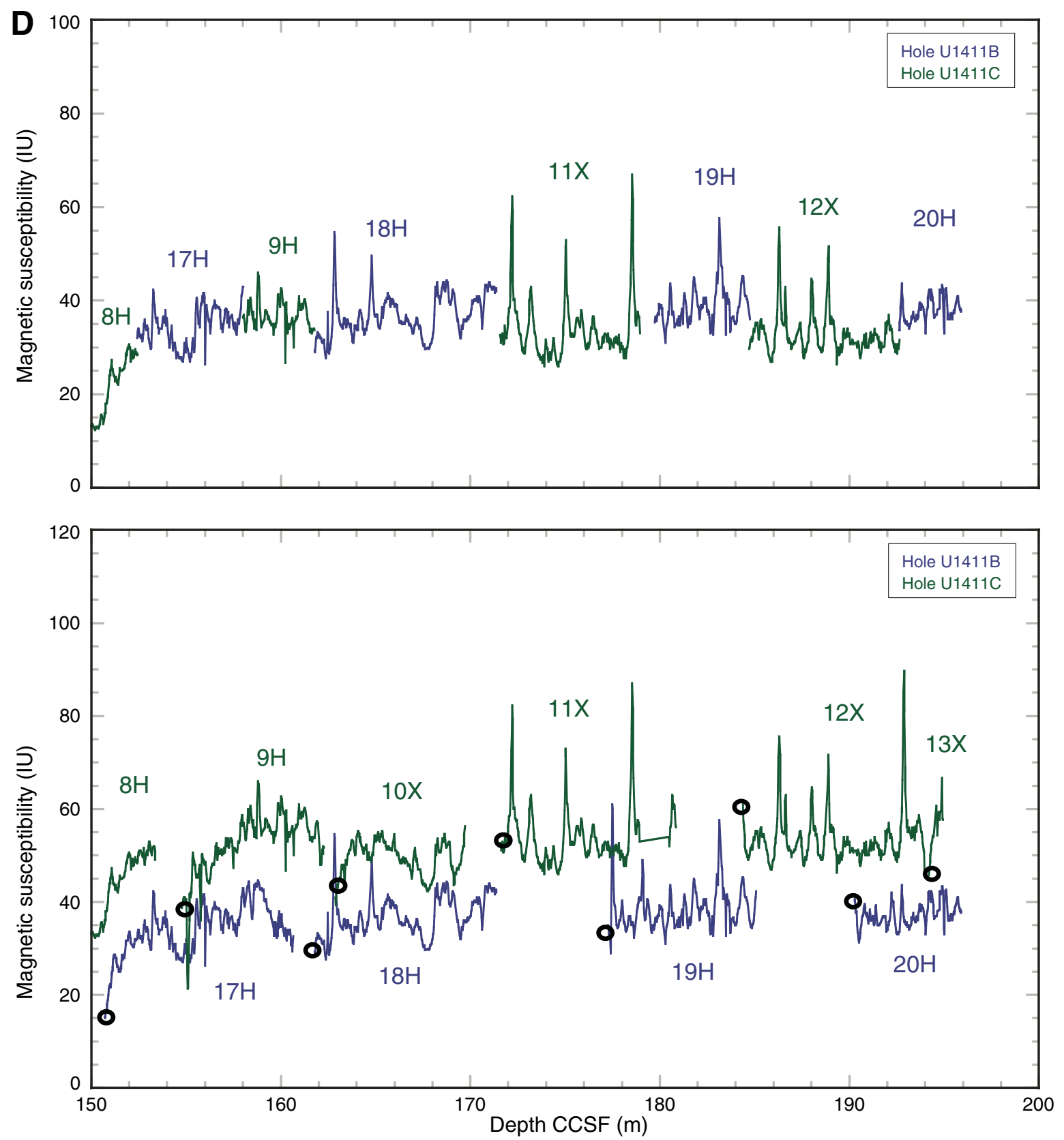
Figure F27 (continued). E. 200-250 m CCSF. (Continued on next page.)
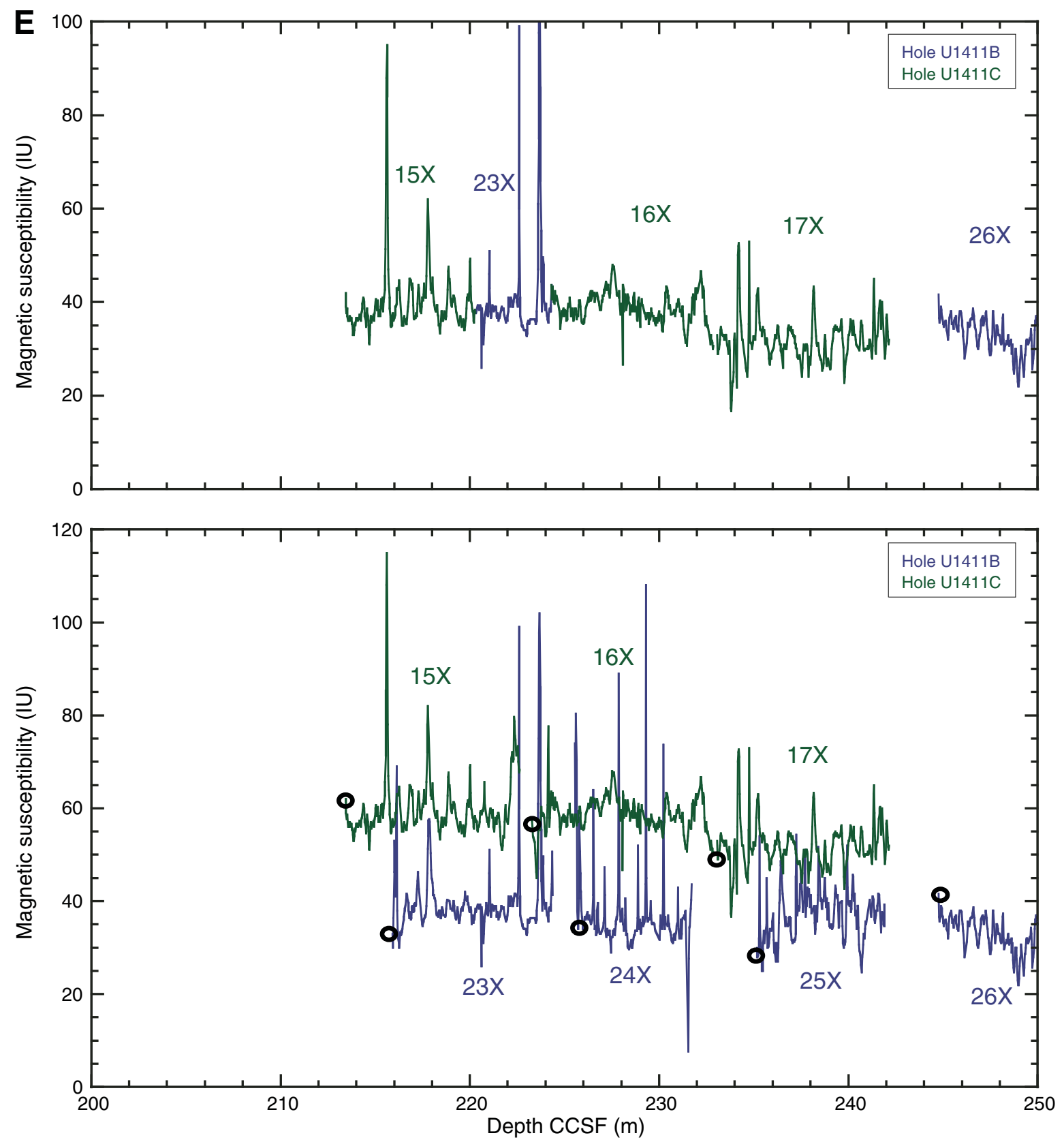
Figure F27 (continued). F. 250-300 m CCSF.

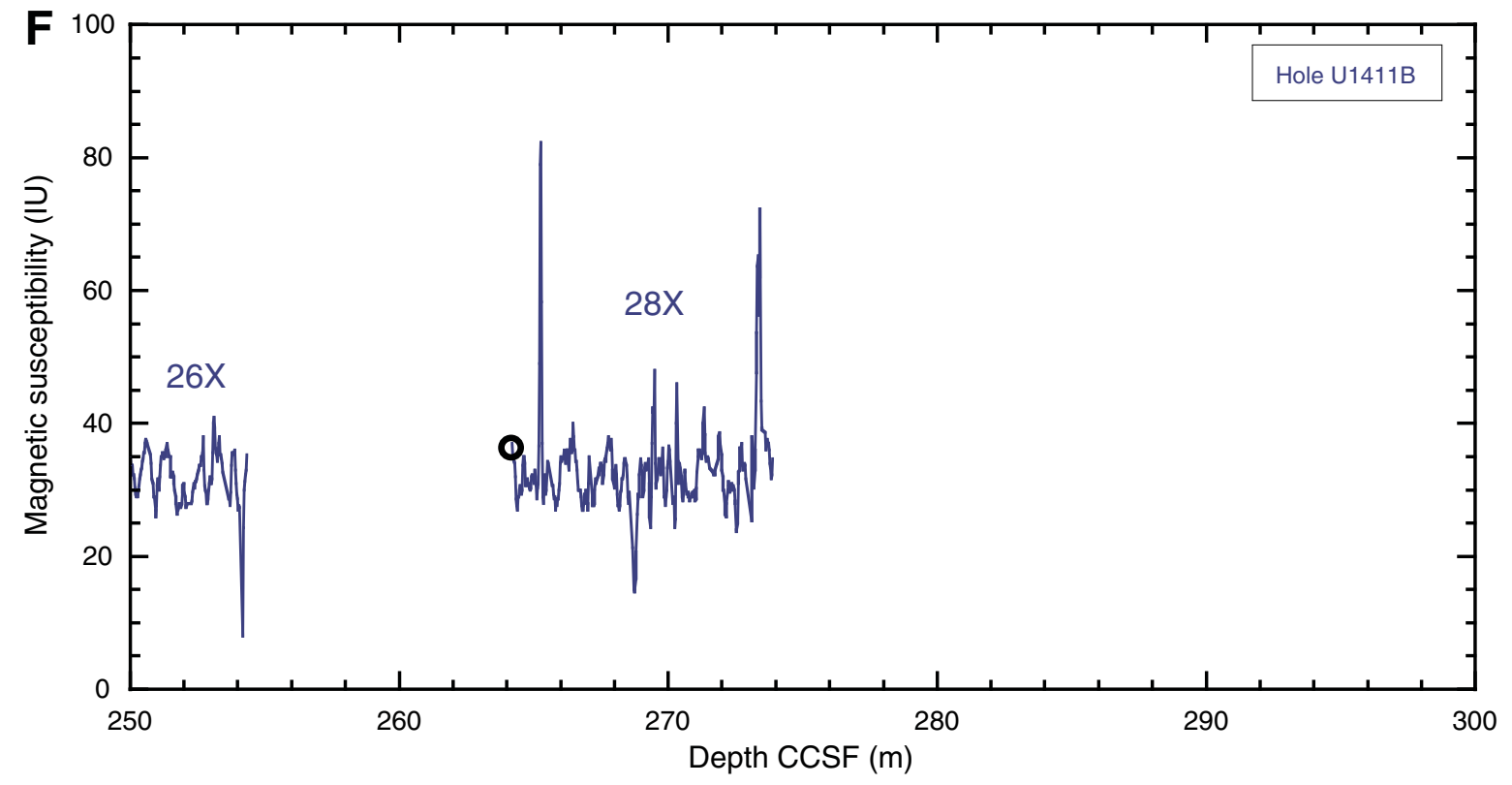


Figure F28. Plot of mbsf depth vs. CCSF depth, Site U1411C. The growth factors are equal to the slopes of the regression lines.

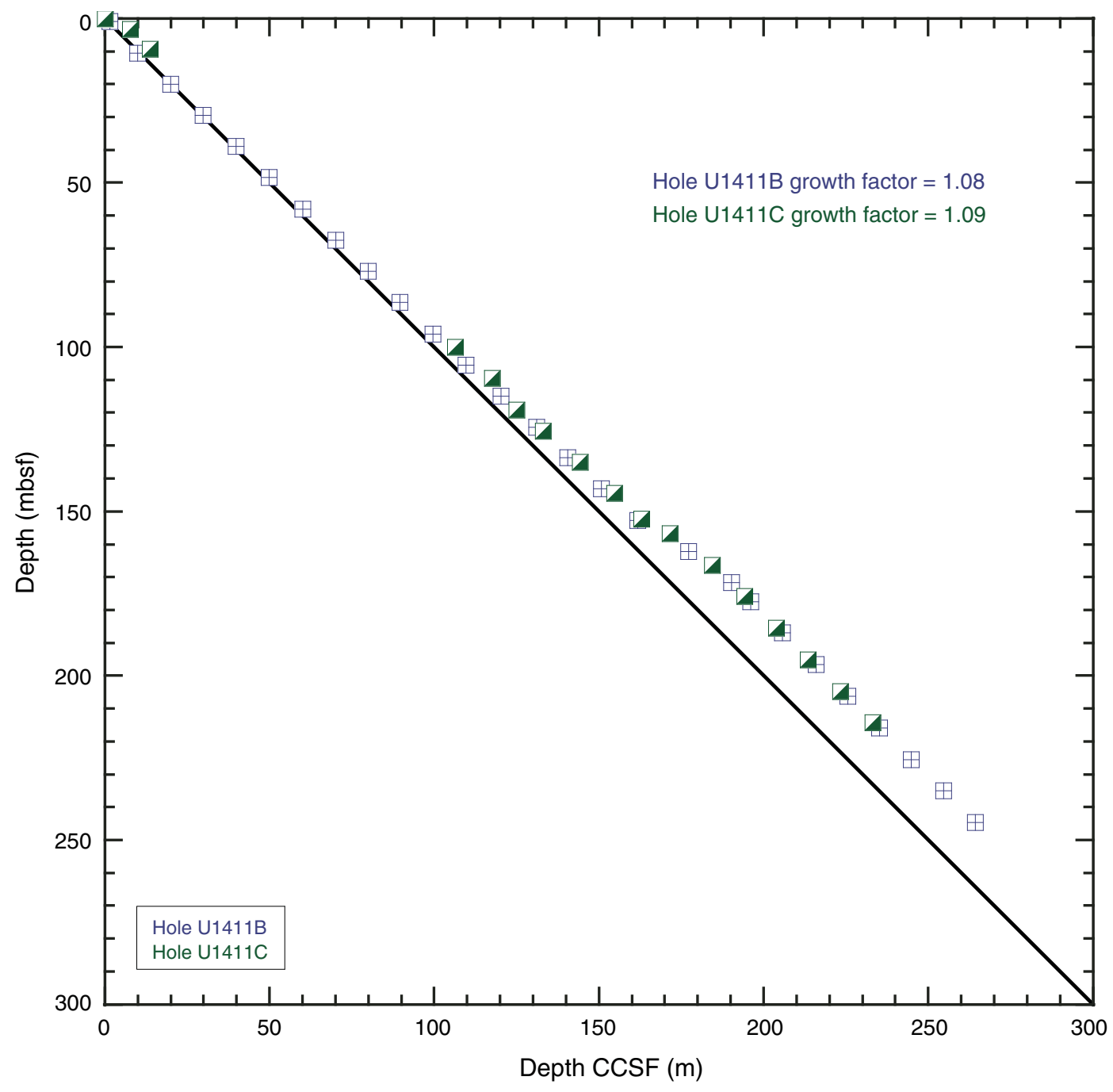


Figure F29. Plot of XRF core scanning $\mathrm{Ca} / \mathrm{Fe}$ data, Site U1411. Ca/Fe data in this depth interval better reflects the correlation between holes as a result of gaps in shipboard physical property data. Top panel shows the spliced section. Bottom panel shows Ca/Fe records from both holes. Data from Hole U1411C are offset by 10 to aid visualization. Open circles indicate core tops.
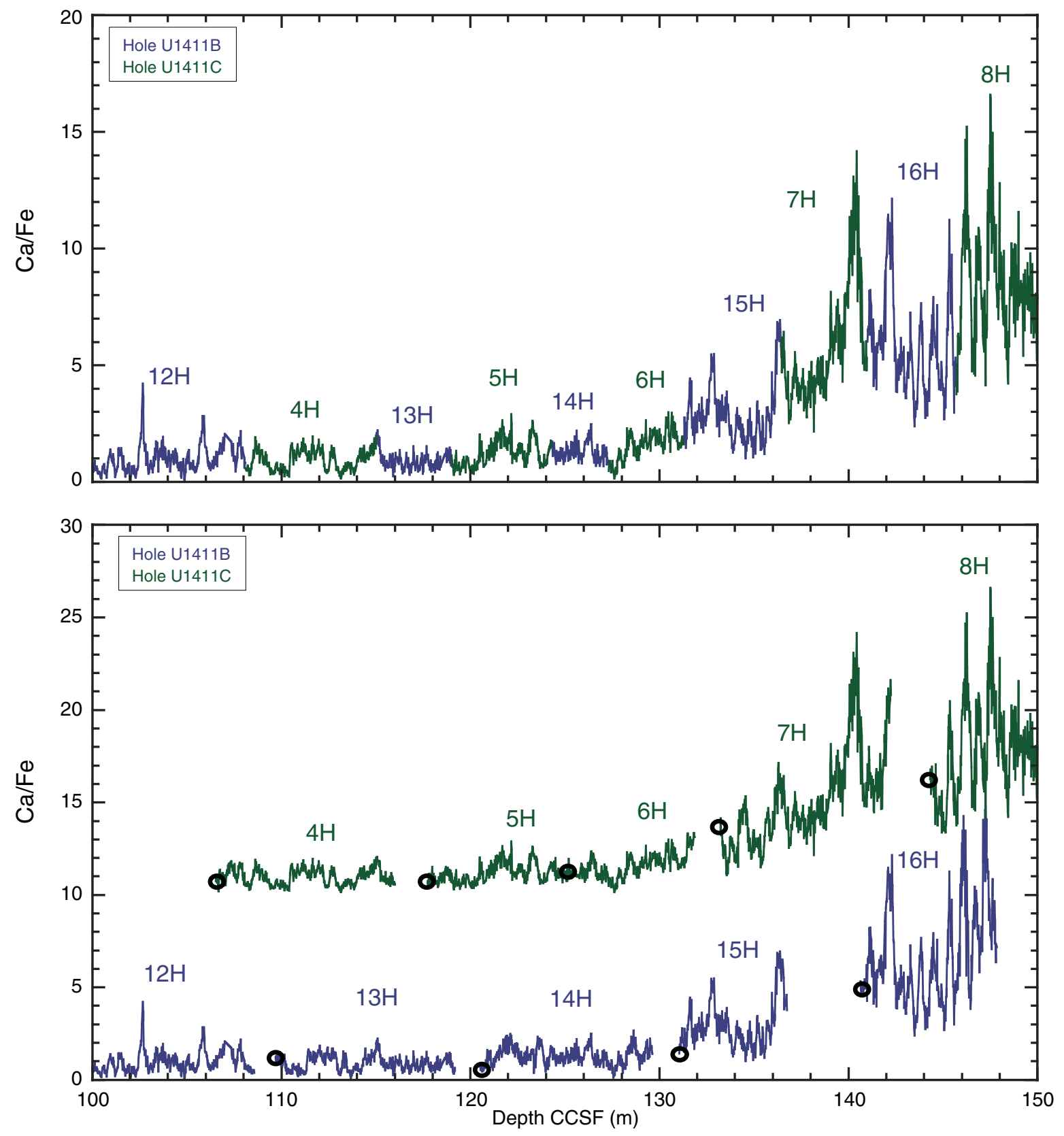
Table T1. Coring summary, Site U1411.

\begin{tabular}{|c|c|c|c|c|c|c|c|c|c|c|}
\hline \multirow[b]{2}{*}{ Core } & \multirow[b]{2}{*}{$\begin{array}{c}\text { Date } \\
(2012)\end{array}$} & \multirow[b]{2}{*}{$\begin{array}{l}\text { Time } \\
\text { UTC } \\
\text { (h) }\end{array}$} & \multicolumn{2}{|c|}{ Depth DSF $(m)$} & \multirow[b]{2}{*}{$\begin{array}{l}\text { Interval } \\
\text { cored } \\
(\mathrm{m})\end{array}$} & \multirow[b]{2}{*}{$\begin{array}{l}\text { Curated } \\
\text { length } \\
(\mathrm{m})\end{array}$} & \multicolumn{2}{|c|}{ Depth CSF-A (m) } & \multirow[b]{2}{*}{$\begin{array}{l}\text { Recovery } \\
\text { (\%) }\end{array}$} & \multirow[b]{2}{*}{$\begin{array}{l}\text { Sections } \\
(N)\end{array}$} \\
\hline & & & $\begin{array}{l}\text { Top of } \\
\text { cored } \\
\text { interval }\end{array}$ & $\begin{array}{l}\text { Bottom } \\
\text { of cored } \\
\text { interval }\end{array}$ & & & $\begin{array}{l}\text { Top of } \\
\text { core }\end{array}$ & $\begin{array}{l}\text { Bottom of } \\
\text { core }\end{array}$ & & \\
\hline \multicolumn{11}{|c|}{ 342-U1411A- } \\
\hline $1 \mathrm{H}$ & $26 \mathrm{Jul}$ & 0210 & 0.0 & $\begin{array}{l}9.5 \\
\text { Totals: }\end{array}$ & $\begin{array}{l}9.5 \\
9.5\end{array}$ & $\begin{array}{l}9.87 \\
9.87\end{array}$ & 0.00 & 9.87 & $\begin{array}{l}104 \\
104\end{array}$ & $\frac{8}{8}$ \\
\hline \multicolumn{11}{|c|}{ 342-U1411B- } \\
\hline $1 \mathrm{H}$ & $26 \mathrm{Jul}$ & 0325 & 0.0 & 0.9 & 0.9 & 0.93 & 0.00 & 0.93 & 103 & 2 \\
\hline $2 \mathrm{H}$ & $26 \mathrm{Jul}$ & 0435 & 0.9 & 10.4 & 9.5 & 9.98 & 0.90 & 10.88 & 105 & 8 \\
\hline $3 \mathrm{H}$ & $26 \mathrm{Jul}$ & 0535 & 10.4 & 19.9 & 9.5 & 9.90 & 10.40 & 20.30 & 104 & 8 \\
\hline $4 \mathrm{H}$ & $26 \mathrm{Jul}$ & 0705 & 19.9 & 29.4 & 9.5 & 9.98 & 19.90 & 29.88 & 105 & 8 \\
\hline $5 \mathrm{H}$ & $26 \mathrm{Jul}$ & 0755 & 29.4 & 38.9 & 9.5 & 9.98 & 29.40 & 39.38 & 105 & 8 \\
\hline $6 \mathrm{H}$ & $26 \mathrm{Jul}$ & 0850 & 38.9 & 48.4 & 9.5 & 10.08 & 38.90 & 48.98 & 106 & 8 \\
\hline $7 \mathrm{H}$ & $26 \mathrm{Jul}$ & 0945 & 48.4 & 57.9 & 9.5 & 10.06 & 48.40 & 58.46 & 106 & 8 \\
\hline $8 \mathrm{H}$ & $26 \mathrm{Jul}$ & 1035 & 57.9 & 67.4 & 9.5 & 10.12 & 57.90 & 68.02 & 107 & 8 \\
\hline $9 \mathrm{H}$ & $26 \mathrm{Jul}$ & 1130 & 67.4 & 76.9 & 9.5 & 9.77 & 67.40 & 77.17 & 103 & 9 \\
\hline $10 \mathrm{H}$ & $26 \mathrm{Jul}$ & 1220 & 76.9 & 86.4 & 9.5 & 9.73 & 76.90 & 86.63 & 102 & 8 \\
\hline $11 \mathrm{H}$ & $26 \mathrm{Jul}$ & 1310 & 86.4 & 95.9 & 9.5 & 9.89 & 86.40 & 96.29 & 104 & 8 \\
\hline $12 \mathrm{H}$ & $26 \mathrm{Jul}$ & 1405 & 95.9 & 105.4 & 9.5 & 9.50 & 95.90 & 105.40 & 100 & 8 \\
\hline $13 \mathrm{H}$ & $26 \mathrm{Jul}$ & 1500 & 105.4 & 114.9 & 9.5 & 9.98 & 105.40 & 115.38 & 105 & 8 \\
\hline $14 \mathrm{H}$ & $26 \mathrm{Jul}$ & 1610 & 114.9 & 124.4 & 9.5 & 9.55 & 114.90 & 124.45 & 101 & 8 \\
\hline $15 \mathrm{H}$ & $26 \mathrm{Jul}$ & 1710 & 124.4 & 133.6 & 9.2 & 9.20 & 124.40 & 133.60 & 100 & 7 \\
\hline $16 \mathrm{H}$ & $26 \mathrm{Jul}$ & 1910 & 133.6 & 143.1 & 9.5 & 7.78 & 133.60 & 141.38 & 82 & 6 \\
\hline $17 \mathrm{H}$ & $26 \mathrm{Jul}$ & 2035 & 143.1 & 152.6 & 9.5 & 10.25 & 143.10 & 153.35 & 108 & 8 \\
\hline $18 \mathrm{H}$ & $26 \mathrm{Jul}$ & 2240 & 152.6 & 162.1 & 9.5 & 9.88 & 152.60 & 162.48 & 104 & 8 \\
\hline $19 \mathrm{H}$ & $27 \mathrm{Jul}$ & 0005 & 162.1 & 171.6 & 9.5 & 10.31 & 162.10 & 172.41 & 109 & 8 \\
\hline $20 \mathrm{H}$ & $27 \mathrm{Jul}$ & 0130 & 171.6 & 177.4 & 5.8 & 5.83 & 171.60 & 177.43 & 101 & 4 \\
\hline $21 x$ & $27 \mathrm{Jul}$ & 0345 & 177.4 & 187.0 & 9.6 & 0.69 & 177.40 & 178.09 & 7 & 2 \\
\hline $22 x$ & $27 \mathrm{Jul}$ & 0505 & 187.0 & 196.6 & 9.6 & 0.39 & 187.00 & 187.39 & 4 & 2 \\
\hline $23 x$ & $27 \mathrm{Jul}$ & 0620 & 196.6 & 206.2 & 9.6 & 8.70 & 196.60 & 205.30 & 91 & 7 \\
\hline $24 X$ & $27 \mathrm{Jul}$ & 0745 & 206.2 & 215.8 & 9.6 & 6.38 & 206.20 & 212.58 & 66 & 5 \\
\hline $25 x$ & $27 \mathrm{Jul}$ & 0920 & 215.8 & 225.4 & 9.6 & 6.97 & 215.80 & 222.77 & 73 & 6 \\
\hline $26 \mathrm{X}$ & $27 \mathrm{Jul}$ & 0110 & 225.4 & 235.0 & 9.6 & 9.80 & 225.40 & 235.20 & 102 & 8 \\
\hline $27 x$ & $27 \mathrm{Jul}$ & 1235 & 235.0 & 244.6 & 9.6 & 8.41 & 235.00 & 243.41 & 88 & 8 \\
\hline \multirow[t]{2}{*}{$28 \mathrm{X}$} & $27 \mathrm{Jul}$ & 1415 & 244.6 & 254.2 & 9.6 & 9.90 & 244.60 & 254.50 & 103 & 8 \\
\hline & & & & Totals: & 254.2 & 233.94 & & & 93 & 194 \\
\hline \multicolumn{11}{|c|}{ 342-U1411C- } \\
\hline $1 \mathrm{H}$ & $27 \mathrm{Jul}$ & 1525 & 0.0 & 3.2 & 3.2 & 3.29 & 0.00 & 3.29 & 103 & 4 \\
\hline $2 \mathrm{H}$ & $27 \mathrm{Jul}$ & 2025 & 3.2 & 9.2 & 6.0 & 6.04 & 3.20 & 9.24 & 101 & 5 \\
\hline 31 & $28 \mathrm{Jul}$ & 0040 & \multicolumn{8}{|c|}{${ }^{\star * \star *}$ Drilled from 9.2 to $100.0 \mathrm{~m} \mathrm{DSF}^{\star * * \star *}$} \\
\hline $4 \mathrm{H}$ & $28 \mathrm{Jul}$ & 0135 & 100.0 & 109.5 & 9.5 & 10.09 & 100.00 & 110.09 & 106 & 8 \\
\hline $5 \mathrm{H}$ & $28 \mathrm{Jul}$ & 0235 & 109.5 & 119.0 & 9.5 & 8.34 & 109.50 & 117.84 & 88 & 7 \\
\hline $6 \mathrm{H}$ & $28 \mathrm{Jul}$ & 0340 & 119.0 & 125.5 & 6.5 & 7.48 & 119.00 & 126.48 & 115 & 8 \\
\hline $7 \mathrm{H}$ & $28 \mathrm{Jul}$ & 0620 & 125.5 & 135.0 & 9.5 & 9.51 & 125.50 & 135.01 & 100 & 7 \\
\hline $8 \mathrm{H}$ & $28 \mathrm{Jul}$ & 0730 & 135.0 & 144.5 & 9.5 & 9.44 & 135.00 & 144.44 & 99 & 7 \\
\hline $9 \mathrm{H}$ & $28 \mathrm{Jul}$ & 0820 & 144.5 & 152.2 & 7.7 & 7.79 & 144.50 & 152.29 & 101 & 6 \\
\hline $10 x$ & $28 \mathrm{Jul}$ & 1055 & 152.2 & 156.7 & 4.5 & 7.26 & 152.20 & 159.46 & 161 & 6 \\
\hline $11 x$ & $28 \mathrm{Jul}$ & 1200 & 156.7 & 166.3 & 9.6 & 9.66 & 156.70 & 166.36 & 101 & 8 \\
\hline $12 x$ & $28 \mathrm{Jul}$ & 1300 & 166.3 & 175.9 & 9.6 & 9.83 & 166.30 & 176.13 & 102 & 8 \\
\hline $13 x$ & $28 \mathrm{Jul}$ & 1400 & 175.9 & 185.5 & 9.6 & 0.98 & 175.90 & 176.88 & 10 & 2 \\
\hline $14 X$ & $28 \mathrm{Jul}$ & 1515 & 185.5 & 195.1 & 9.6 & 0.16 & 185.50 & 185.66 & 2 & 2 \\
\hline $15 x$ & $28 \mathrm{Jul}$ & 1650 & 195.1 & 204.7 & 9.6 & 9.67 & 195.10 & 204.77 & 101 & 8 \\
\hline $16 \mathrm{X}$ & $28 \mathrm{Jul}$ & 1840 & 204.7 & 214.3 & 9.6 & 9.80 & 204.70 & 214.50 & 102 & 8 \\
\hline \multirow[t]{3}{*}{$17 x$} & $28 \mathrm{Jul}$ & 2005 & 214.3 & 223.9 & 9.6 & 9.28 & 214.30 & 223.58 & 97 & 7 \\
\hline & & & & Totals: & 223.9 & 118.62 & & & 88 & 101 \\
\hline & & & \multicolumn{2}{|c|}{ Site U1411 totals: } & 487.6 & 362.43 & & & 95 & 303 \\
\hline
\end{tabular}

DSF = drilling depth below seafloor, CSF-A = core depth below seafloor. $\mathrm{H}=$ advanced piston core, $\mathrm{X}=$ extended core barrel core, numeric core type $=$ drilled interval. 
Table T2. Lithostratigraphic unit intervals, Site U1411.

\begin{tabular}{|c|c|c|c|c|}
\hline \multirow{2}{*}{$\begin{array}{l}\text { Lith. } \\
\text { unit }\end{array}$} & \multicolumn{2}{|c|}{ Core, section, interval $(\mathrm{cm})$} & \multicolumn{2}{|c|}{ Depth (mbsf) } \\
\hline & Top & Bottom & Top & Bottom \\
\hline 1 & $\begin{array}{c}\text { 342-U1411A- } \\
\mathrm{H}-10^{0}\end{array}$ & 342-U1411A- & O & 987 \\
\hline & 342-U1411B- & 342-U1411B- & & \\
\hline 1 & $1 \mathrm{H}-1,0$ & $3 \mathrm{H}-3,95$ & 0.00 & 14.35 \\
\hline II & $3 \mathrm{H}-3,95$ & $24 \mathrm{X}-\mathrm{CC}, 38$ & 14.35 & 212.58 \\
\hline III & $25 X-1,0$ & $28 \mathrm{X}-\mathrm{CC}, 46$ & 215.80 & 254.50 \\
\hline & 342-U1411C- & 342-U1411C- & & \\
\hline I & $1 \mathrm{H}-1,0$ & $2 \mathrm{H}-\mathrm{CC}, 8$ & 0.00 & 9.24 \\
\hline II & $4 \mathrm{H}-1,0$ & $17 X-1,64$ & 100.00 & 214.94 \\
\hline III & $17 X-1,64$ & $17 \mathrm{H}-\mathrm{CC}, 42$ & 214.94 & 223.58 \\
\hline
\end{tabular}


Table T3. Biostratigraphic and magnetostratigraphic datums, Hole U1411B.

\begin{tabular}{|c|c|c|c|c|c|c|c|}
\hline \multirow{2}{*}{$\begin{array}{l}\text { Datum tie } \\
\text { point }\end{array}$} & \multirow[b]{2}{*}{ Datum } & \multirow[b]{2}{*}{ Datum type } & \multirow[b]{2}{*}{ Zone } & \multirow{2}{*}{$\begin{array}{l}\text { Age } \\
(\mathrm{Ma})\end{array}$} & \multicolumn{3}{|c|}{ Depth (mbsf) } \\
\hline & & & & & Top & Bottom & Midpoint \\
\hline D01 & T Pseudoemiliania lacunosa & Calcareous nannofossil & NN20 & 0.44 & 0.89 & 0.89 & 0.89 \\
\hline \multirow{5}{*}{ D04 } & T Triquetrorhabdulus carinatus & Calcareous nannofossil & NN3 & 18.28 & 17.20 & 18.80 & 18.00 \\
\hline & T? Sphenolithus distentus & Calcareous nannofossil & NP25 & 26.84 & 48.95 & 58.42 & 53.68 \\
\hline & B Sphenolithus ciperoensis & Calcareous nannofossil & NP24 & 29.62 & 78.95 & 81.95 & 80.45 \\
\hline & B Sphenolithus distentus & Calcareous nannofossil & & 30.00 & 91.20 & 94.20 & 92.70 \\
\hline & T Reticulofenestra umbilicus (>14 $\mu \mathrm{m})$ & Calcareous nannofossil & NP23 & 32.02 & 97.70 & 102.12 & 99.91 \\
\hline \multirow[t]{9}{*}{ D12 } & T Isthmolithus recurvus & Calcareous nannofossil & & 32.49 & 102.12 & 105.36 & 103.74 \\
\hline & T Coccolithus formosus & Calcareous nannofossil & NP22 & 32.92 & 135.58 & 138.10 & 136.84 \\
\hline & T Discoaster saipanensis & Calcareous nannofossil & NP21 & 34.44 & 163.60 & 166.60 & 165.10 \\
\hline & T Discoaster barbadiensis & Calcareous nannofossil & & & 177.40 & 178.05 & 177.72 \\
\hline & Bc? Isthmolithus recurvus & Calcareous nannofossil & NP19/NP20 & 36.97 & 222.73 & 235.15 & 228.94 \\
\hline & Ta Cribrocentrum erbae & Calcareous nannofossil & & 37.58 & 238.82 & 240.33 & 239.58 \\
\hline & $\mathrm{Br}$ Isthmolithus recurvus & Calcareous nannofossil & & 37.64 & 249.98 & 251.24 & 250.61 \\
\hline & Ba Cribrocentrum erbae & Calcareous nannofossil & & 38.07 & 252.77 & 253.53 & 253.15 \\
\hline & B Chiasmolithus oamaruensis & Calcareous nannofossil & NP18 & 38.03 & 254.46 & 254.46 & 254.46 \\
\hline D18 & T Chiasmolithus grandis & Calcareous nannofossil & & 37.98 & 252.77 & 253.53 & 253.15 \\
\hline \multirow[t]{3}{*}{ D10 } & T Turborotalia ampliapertura & Planktonic foraminifer & $\mathrm{O} 3 / \mathrm{O} 2$ & 30.28 & 86.59 & 96.25 & 91.42 \\
\hline & T Pseudohastigerina spp. & Planktonic foraminifer & $\mathrm{O} 2 / 01$ & 32.10 & 115.35 & 124.43 & 119.89 \\
\hline & T Hantkenina albamensis & Planktonic foraminifer & O1/E16 & 33.89 & 156.71 & 158.21 & 157.46 \\
\hline \multirow[t]{3}{*}{ D15 } & T Turborotalia cerroazulensis & Planktonic foraminifer & Within E16 & 34.03 & 159.71 & 161.21 & 160.46 \\
\hline & T Cribrohantkenina inflata & Planktonic foraminifer & Within E16 & 34.22 & 161.21 & 162.45 & 161.83 \\
\hline & T Globigerinatheka index & Planktonic foraminifer & E16/E15 & 34.61 & 162.45 & 172.38 & 167.41 \\
\hline D17 & T Globigerinatheka semiinvoluta & Planktonic foraminifer & E15/E14 & 36.18 & 205.25 & 212.54 & 208.90 \\
\hline \multirow[t]{4}{*}{ D02 } & C1n (Brunhes)/C1r.1r (Matuyama) & Chron boundary & & 0.78 & & & 7.75 \\
\hline & C1r.1r (Matuyama)/C1r.1n (Jaramillo) & Chron boundary & & 0.99 & & & 9.08 \\
\hline & C1r.1n (Jaramillo)/C1r.2r & Chron boundary & & 1.07 & & & 9.65 \\
\hline & C1r.2r/C1r.2n (Cobb Mountain) & Chron boundary & & 1.17 & & & 10.17 \\
\hline D03 & C1r.2n (Cobb Mountain)/C1r.3r & Chron boundary & & 1.19 & & & 10.37 \\
\hline D05 & $\mathrm{C} 8 \mathrm{n} .2 \mathrm{n} / \mathrm{C} 8 \mathrm{r}$ & Chron boundary & & 25.99 & & & 25.91 \\
\hline D06 & $\mathrm{C} 8 \mathrm{r} / \mathrm{C} 9 \mathrm{n}$ & Chron boundary & & 26.42 & & & 32.13 \\
\hline \multirow[t]{4}{*}{ D07 } & $\mathrm{C} 9 \mathrm{n} / \mathrm{C} 9 \mathrm{r}$ & Chron boundary & & 27.44 & & & 54.41 \\
\hline & C9r/C10n.1n & Chron boundary & & 27.86 & & & 59.10 \\
\hline & C10n.1n/C10n.1r & Chron boundary & & 28.09 & & & 62.20 \\
\hline & C10n.1r/C10n.2n & Chron boundary & & 28.14 & & & 63.44 \\
\hline D08 & C10n.2n/C10r & Chron boundary & & 28.28 & & & 65.41 \\
\hline D09 & $\mathrm{C} 11 \mathrm{n} .2 \mathrm{n} / \mathrm{C} 11 \mathrm{r}$ & Chron boundary & & 29.97 & & & 82.59 \\
\hline D13 & $\mathrm{C} 12 \mathrm{r} / \mathrm{C} 13 \mathrm{n}$ & Chron boundary & & 33.16 & & & 128.79 \\
\hline D14 & $\mathrm{C} 13 \mathrm{n} / \mathrm{C} 13 \mathrm{r}$ & Chron boundary & & 33.71 & & & 144.15 \\
\hline D16 & $\mathrm{C} 13 \mathrm{r} / \mathrm{C} 15 \mathrm{n}$ & Chron boundary & & 35.00 & & & 172.98 \\
\hline
\end{tabular}

$\mathrm{B}=$ base, $\mathrm{Br}=$ base rare, $\mathrm{Bc}=$ Base common, $\mathrm{Ba}=$ base of acme, $\mathrm{T}=$ top, $\mathrm{Ta}=$ top of acme. 
Table T4. Calcareous nannofossil datums, Site U1411.

\begin{tabular}{|c|c|c|c|c|c|c|c|c|c|}
\hline \multicolumn{2}{|c|}{ Hole, core, section, interval $(\mathrm{cm})$} & \multirow[b]{2}{*}{ Age } & \multirow[b]{2}{*}{ Zone } & \multirow[b]{2}{*}{ Marker species } & \multirow{2}{*}{$\begin{array}{l}\text { Age } \\
(\mathrm{Ma})\end{array}$} & \multicolumn{4}{|c|}{ Depth (mbsf) } \\
\hline Top & Bottom & & & & & Top & Bottom & Midpoint & \pm \\
\hline $342-$ & $342-$ & Pleistocene & & & & & & & \\
\hline U1411B-3H-5, 80 & U1411B-3H-6, 90 & Oligocene & NN3 & T Triquetrorhabdulus carinatus & 18.28 & 17.20 & 18.80 & 18.00 & 0.80 \\
\hline U1411B-6H-CC & U1411B-7H-CC & & NP25 & ?T Sphenolithus distentus & 26.84 & 48.95 & 58.42 & 53.68 & 4.74 \\
\hline U1411B-12H-2, 30 & U1411B-12H-5, 30 & & NP23 & T Reticulofenestra umbilicus (>14 $\mu \mathrm{m}$ ) & 32.02 & 97.70 & 102.12 & 99.91 & 2.21 \\
\hline U1411B-12H-5, 30 & U1411B-12H-CC & & & T Isthmolithus recurvus & 32.49 & 102.12 & 105.36 & 103.74 & 1.62 \\
\hline U1411B-16H-2, 50 & U1411B-16H-3, 150 & Eocene & NP22 & T Coccolithus formosus & 32.92 & 135.58 & 138.10 & 136.84 & 1.26 \\
\hline U1411B-19H-3, 150 & U1411B-19H-CC & & NP21 & T Discoaster saipanensis & 34.44 & 166.60 & 172.38 & 169.49 & 2.89 \\
\hline U1411B-20H-CC & U1411B-21X-CC & & & T Discoaster barbadiensis & & 177.40 & 178.05 & 177.72 & 0.33 \\
\hline U1411B-25X-CC & U1411B-26X-CC & & NP19/NP20 & ?BC Isthmolithus recurvus & 36.97 & 222.73 & 235.15 & 228.94 & 6.21 \\
\hline
\end{tabular}

* = from Agnini et al. (2011) recalibrated to GTS2012. $\mathrm{B}=$ base, $\mathrm{Ba}=$ base of acme, $\mathrm{BC}=$ base common, $\mathrm{Br}=$ base rare, $\mathrm{T}=$ top, $\mathrm{Ta}=$ top of acme.

Table T5. Calcareous nannofossil distribution and abundance, Site U1411. This table is available in an oversized format.

Table T6. Planktonic foraminifer datums, Site U1411.

\begin{tabular}{|c|c|c|c|c|c|c|c|c|c|}
\hline \multicolumn{2}{|c|}{ Hole, core, section, interval $(\mathrm{cm})$} & \multirow[b]{2}{*}{ Age } & \multirow[b]{2}{*}{ Zone } & \multirow[b]{2}{*}{ Marker event } & \multirow{2}{*}{$\begin{array}{l}\text { Age } \\
\text { (Ma) }\end{array}$} & \multirow[b]{2}{*}{ Top } & \multicolumn{3}{|c|}{ Depth (mbsf) } \\
\hline Top & Bottom & & & & & & Bottom & Midpoint & \pm \\
\hline $342-$ & $342-$ & & & & & & & & \\
\hline U1411A-10-CC & U1411A-11-CC & early Oligocene & $\mathrm{O} 3 / \mathrm{O} 2$ & T Turborotalia ampliapertura & 30.28 & 86.59 & 96.25 & 91.42 & 4.83 \\
\hline U1411A-13-CC & U1411A-14-CC & early Oligocene & $\mathrm{O} 2 / \mathrm{O} 1$ & T Pseudohastigerina spp. & 32.10 & 115.35 & 124.43 & 119.89 & 4.54 \\
\hline U1411B-18H-3, 110-112 & U1411B-18H-4, 110-112 & early Oligocene & O1/E16 & T Hantkenina albamensis & 33.89 & 156.71 & 158.21 & 157.46 & 0.75 \\
\hline U1411B-18H-5, 110-112 & U1411B-18H-6, 110-112 & late Eocene & Within E16 & T Turborotalia cerroazulensis & 34.03 & 159.71 & 161.21 & 160.46 & 0.75 \\
\hline U1411B-18H-6, 110-112 & U1411B-18H-CC & late Eocene & Within E16 & T Cribrohantkenina inflata & 34.22 & 161.21 & 162.45 & 161.83 & 0.62 \\
\hline U1411A-18-CC & U1411A-19-CC & late Eocene & E16/E15 & T Globigerinatheka index & 34.61 & 162.45 & 172.38 & 167.41 & 4.97 \\
\hline U1411A-23-CC & U1411A-24-CC & late Eocene & E15/E14 & T Globigerinatheka semiinvoluta & 36.18 & 205.25 & 212.54 & 208.90 & 3.64 \\
\hline
\end{tabular}

$\mathrm{T}=$ top. 
Table T7. Planktonic foraminifer distribution and abundance, Site U1411. (Continued on next page.)

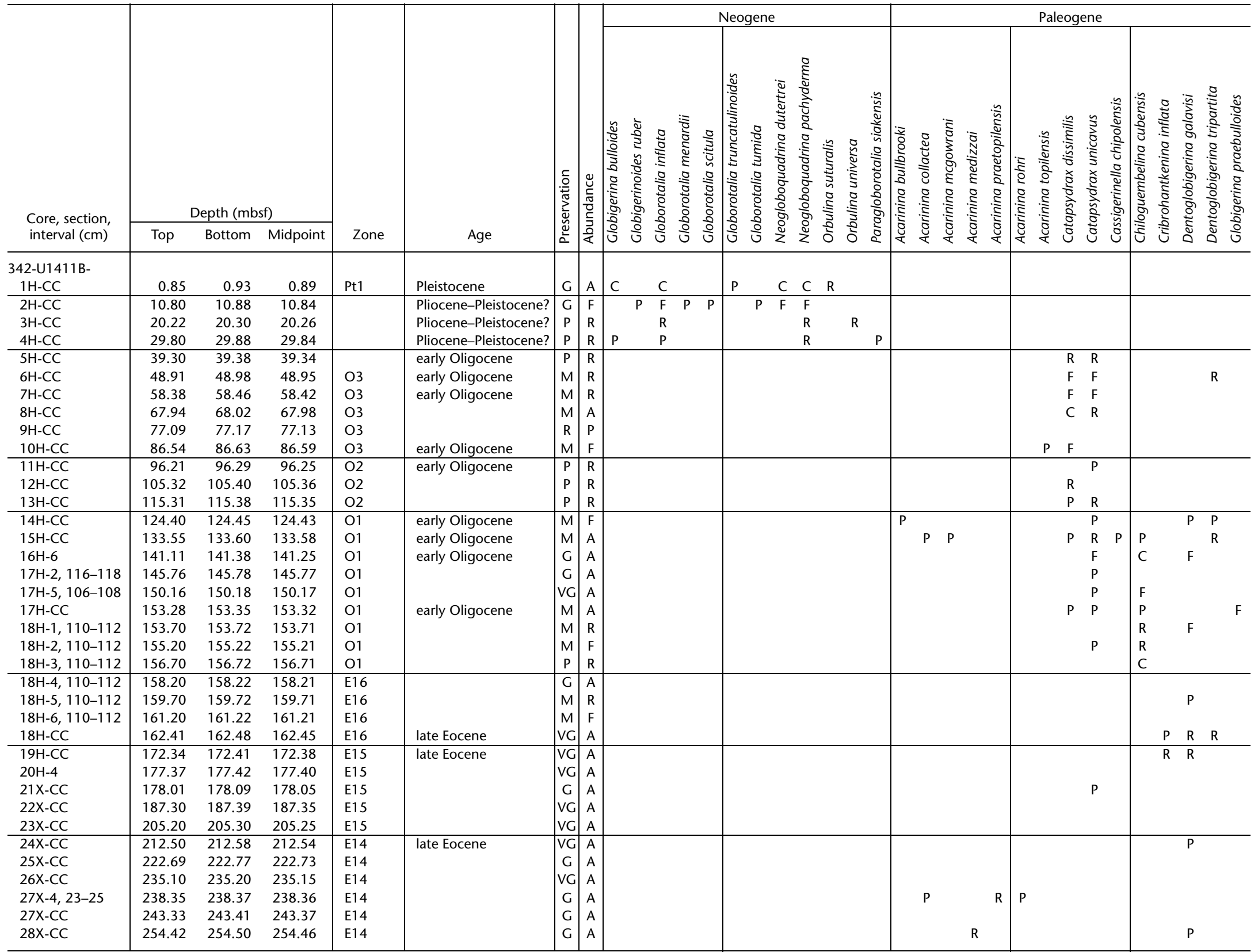

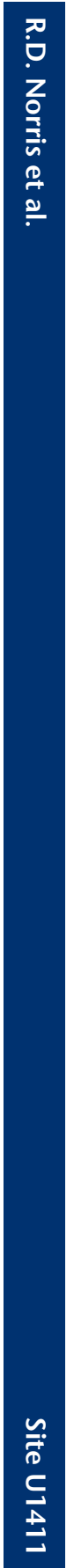

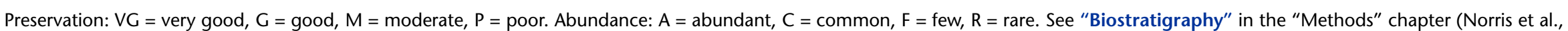
2014a) for preservation and abundance definitions. 


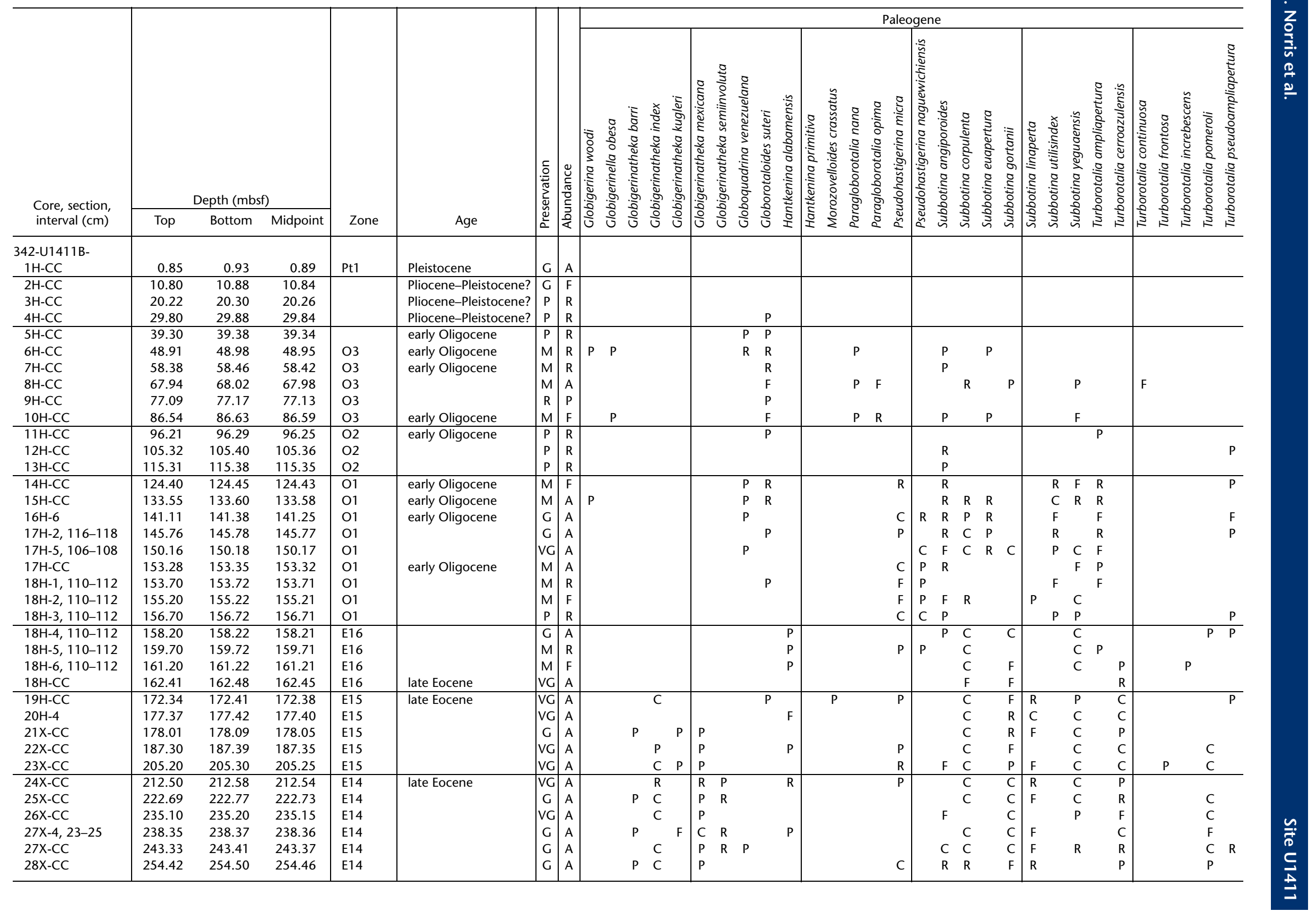




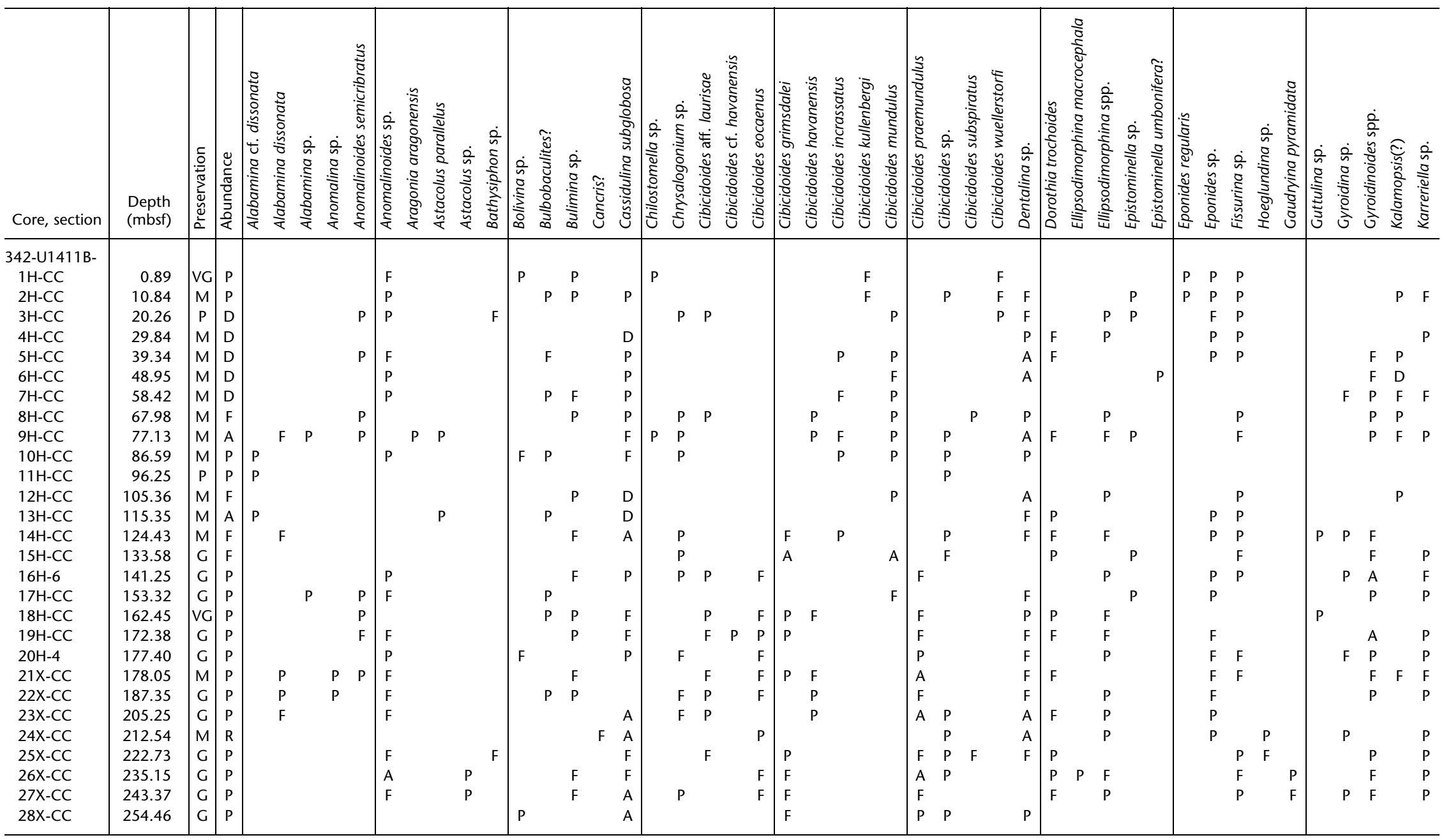

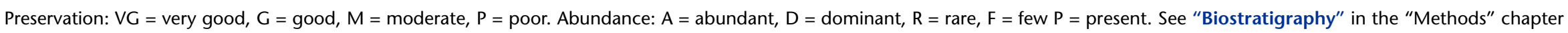
(Norris et al., 2014a) for preservation and abundance definitions. 


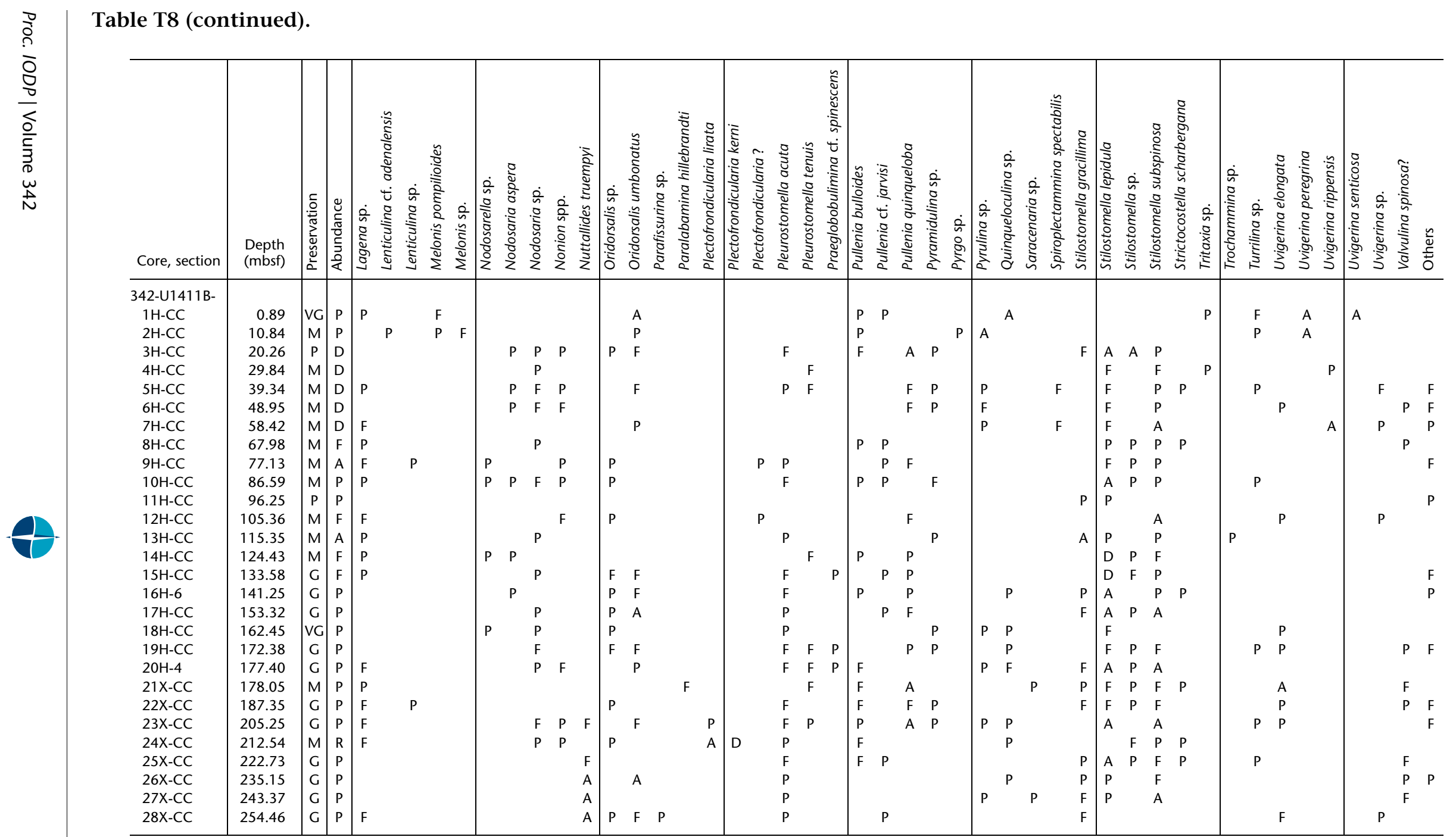


Table T9. Benthic foraminifer abundance and preservation, Site U1411.

\begin{tabular}{|c|c|c|c|}
\hline $\begin{array}{l}\text { Core, section, } \\
\text { interval }(\mathrm{cm})\end{array}$ & $\begin{array}{l}\text { Depth } \\
\text { (mbsf) }\end{array}$ & 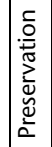 & 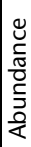 \\
\hline 342-U1411B- & & & \\
\hline $3 \mathrm{H}-3 \mathrm{~W}, 110-112$ & 14.51 & $M$ & $\mathrm{P}$ \\
\hline $3 \mathrm{H}-5 \mathrm{~W}, 110-112$ & 17.51 & G & $\mathrm{P}$ \\
\hline $4 \mathrm{H}-2 \mathrm{~W}, 110-112$ & 22.51 & G & $\mathrm{P}$ \\
\hline $4 \mathrm{H}-5 \mathrm{~W}, 120-122$ & 27.11 & & B \\
\hline $15 \mathrm{H}-2 \mathrm{~W}, 110-112$ & 126.93 & VG & P \\
\hline $15 \mathrm{H}-4 \mathrm{~W}, 110-112$ & 129.87 & $\mathrm{G}$ & $\mathrm{P}$ \\
\hline $16 \mathrm{H}-2 \mathrm{~W}, 110-112$ & 136.21 & G & $\mathrm{R}$ \\
\hline $16 \mathrm{H}-5 \mathrm{~W}, 110-112$ & 140.71 & G & $\mathrm{P}$ \\
\hline $17 \mathrm{H}-2 \mathrm{~W}, 116-118$ & 145.77 & G & $\mathrm{P}$ \\
\hline $17 \mathrm{H}-5 \mathrm{~W}, 106-108$ & 150.17 & VG & $\mathrm{P}$ \\
\hline $18 \mathrm{H}-2 \mathrm{~W}, 110-112$ & 155.21 & G & $\mathrm{P}$ \\
\hline $18 \mathrm{H}-5 \mathrm{~W}, 110-112$ & 159.71 & VG & D \\
\hline $19 \mathrm{H}-2 \mathrm{~W}, 100-102$ & 164.61 & $\mathrm{G}$ & $\mathrm{P}$ \\
\hline $19 \mathrm{H}-5 \mathrm{~W}, 103-105$ & 169.14 & $G$ & $\mathrm{P}$ \\
\hline $20 \mathrm{H}-2 \mathrm{~W}, 100-102$ & 174.11 & G & $\mathrm{P}$ \\
\hline $20 \mathrm{H}-4 \mathrm{~W}, 100-102$ & 177.11 & G & $\mathrm{R}$ \\
\hline $23 \mathrm{X}-2 \mathrm{~W}, 100-102$ & 199.11 & VG & $\mathrm{P}$ \\
\hline $23 X-5 W, 100-102$ & 203.61 & G & $\mathrm{P}$ \\
\hline $24 \mathrm{X}-2 \mathrm{~W}, 100-102$ & 208.71 & G & $\mathrm{P}$ \\
\hline $24 \mathrm{X}-4 \mathrm{~W}, 100-102$ & 211.71 & G & $\mathrm{P}$ \\
\hline 25X-1W, 90-92 & 216.71 & G & $\mathrm{P}$ \\
\hline $25 \mathrm{X}-4 \mathrm{~W}, 60-62$ & 220.91 & VG & $\mathrm{P}$ \\
\hline $26 \mathrm{X}-2 \mathrm{~W}, 100-102$ & 227.91 & G & $\mathrm{F}$ \\
\hline $26 X-5 W, 100-102$ & 232.41 & VG & $\mathrm{P}$ \\
\hline $27 X-2 W, 65-67$ & 236.69 & VG & $\mathrm{P}$ \\
\hline $27 X-4 W, 23-25$ & 238.36 & G & $\mathrm{P}$ \\
\hline $27 X-5 W, 100-102$ & 240.62 & G & $\mathrm{P}$ \\
\hline $28 \mathrm{X}-2 \mathrm{~W}, 100-102$ & 247.11 & $M$ & \\
\hline $28 X-5 W, 100-102$ & 251.61 & $M$ & \\
\hline
\end{tabular}

Preservation: $V G=$ very good, $G=$ good, $M=$ moderate. Abundance: $D=$ dominant, $F=$ few, $P=$ present, $B=$ barren. See "Biostratigraphy" in the "Methods" chapter (Norris et al., 2014a) for preservation and abundance definitions. 
Table T10. Core orientation data, Site U1411.

\begin{tabular}{|c|c|c|c|c|c|}
\hline \multicolumn{2}{|c|}{ Hole U1411A } & \multicolumn{2}{|c|}{ Hole U1411B } & \multicolumn{2}{|c|}{ Hole U1411C } \\
\hline Core & $\operatorname{MTF}\left({ }^{\circ}\right)$ & Core & $\operatorname{MTF}\left({ }^{\circ}\right)$ & Core & $\operatorname{MTF}\left({ }^{\circ}\right)$ \\
\hline \multirow{21}{*}{$\begin{array}{c}\text { 342-U131 } \\
1 \mathrm{H}\end{array}$} & \multirow{21}{*}{132} & \multicolumn{2}{|c|}{ 342-U1311B- } & \multicolumn{2}{|c|}{ 342-U1311C- } \\
\hline & & $1 \mathrm{H}$ & 202 & $1 \mathrm{H}$ & - \\
\hline & & $2 \mathrm{H}$ & 340 & $2 \mathrm{H}$ & 198 \\
\hline & & $3 \mathrm{H}$ & - & $3 \mathrm{H}$ & - \\
\hline & & $4 \mathrm{H}$ & 185 & $4 \mathrm{H}$ & 70 \\
\hline & & $5 \mathrm{H}$ & 48 & $5 \mathrm{H}$ & 166 \\
\hline & & $6 \mathrm{H}$ & 31 & $6 \mathrm{H}$ & 181 \\
\hline & & $7 \mathrm{H}$ & 197 & $7 \mathrm{H}$ & 227 \\
\hline & & $8 \mathrm{H}$ & 149 & $8 \mathrm{H}$ & 97 \\
\hline & & $9 \mathrm{H}$ & 277 & $9 \mathrm{H}$ & 8 \\
\hline & & $10 \mathrm{H}$ & 321 & $10 \mathrm{H}$ & \\
\hline & & $11 \mathrm{H}$ & 327 & $11 \mathrm{H}$ & \\
\hline & & $12 \mathrm{H}$ & 19 & $12 \mathrm{H}$ & \\
\hline & & $13 \mathrm{H}$ & 124 & $13 \mathrm{H}$ & \\
\hline & & $14 \mathrm{H}$ & 95 & $14 \mathrm{H}$ & \\
\hline & & $15 \mathrm{H}$ & 201 & $15 \mathrm{H}$ & \\
\hline & & $16 \mathrm{H}$ & 188 & $16 \mathrm{H}$ & \\
\hline & & $17 \mathrm{H}$ & 350 & $17 \mathrm{H}$ & \\
\hline & & $18 \mathrm{H}$ & 227 & $18 \mathrm{H}$ & \\
\hline & & $19 \mathrm{H}$ & 57 & $19 \mathrm{H}$ & \\
\hline & & $20 \mathrm{H}$ & 64 & $20 \mathrm{H}$ & \\
\hline
\end{tabular}

MTF = magnetic tool face orientation from geomagnetic north. $-=$ no tool data. 
Table T11. Summary of AF demagnetization results for discrete samples, Hole U1411B. (Continued on next page.)

\begin{tabular}{|c|c|c|c|c|c|c|c|}
\hline $\begin{array}{l}\text { Core, section, } \\
\text { interval }(\mathrm{cm})\end{array}$ & $\begin{array}{l}\text { Depth } \\
\text { (mbsf) }\end{array}$ & $\begin{array}{c}\text { Declination } \\
20 \mathrm{mT} \text { or PCA } \\
\left({ }^{\circ}\right)\end{array}$ & $\begin{array}{c}\text { Inclination } \\
20 \mathrm{mT} \text { or PCA } \\
\left(^{\circ}\right)\end{array}$ & $\begin{array}{l}\text { PCA } \\
\text { MAD } \\
\left({ }^{\circ}\right)\end{array}$ & $\begin{array}{l}\mathrm{PCA} \\
\text { range } \\
(\mathrm{mT})\end{array}$ & $\begin{array}{l}\text { NRM } \\
20 \mathrm{mT} \\
(\mathrm{A} / \mathrm{m})\end{array}$ & $\begin{array}{l}\text { Measurement } \\
\text { error } \\
\text { (\%) }\end{array}$ \\
\hline \multicolumn{8}{|l|}{ 342-U1411B- } \\
\hline $2 \mathrm{H}-3 \mathrm{~W}, 75-77$ & 4.66 & 10.8 & 70.4 & & & $1.96 \mathrm{E}-02$ & 4.3 \\
\hline $2 \mathrm{H}-6 \mathrm{~W}, 62-64$ & 9.03 & 210.2 & -63.2 & & & $1.22 \mathrm{E}-02$ & 3.5 \\
\hline $2 \mathrm{H}-7 \mathrm{~W}, 40-42$ & 10.31 & 232.8 & -65.9 & & & $8.60 \mathrm{E}-03$ & 4.8 \\
\hline $3 \mathrm{H}-2 \mathrm{~W}, 75-77$ & 12.66 & 265.9 & 51.8 & & & $2.01 \mathrm{E}-03$ & 3.7 \\
\hline $3 \mathrm{H}-3 \mathrm{~W}, 75-77$ & 14.16 & 16.1 & 32.1 & & & $1.26 \mathrm{E}-03$ & 3.5 \\
\hline $3 \mathrm{H}-4 \mathrm{~W}, 75-77$ & 15.66 & -53.7 & 26.3 & & & $1.62 \mathrm{E}-04$ & 11.0 \\
\hline $3 \mathrm{H}-5 \mathrm{~W}, 75-77$ & 17.16 & -83.6 & 22.4 & & & $1.76 \mathrm{E}-04$ & 9.3 \\
\hline $3 \mathrm{H}-6 \mathrm{~W}, 75-77$ & 18.66 & 132.0 & 23.9 & & & $1.44 \mathrm{E}-04$ & 5.1 \\
\hline $3 \mathrm{H}-7 \mathrm{~W}, 30-32$ & 19.71 & -52.0 & -43.6 & & & $1.39 \mathrm{E}-04$ & 10.7 \\
\hline $4 \mathrm{H}-2 \mathrm{~W}, 75-77$ & 22.16 & 34.8 & 73.3 & & & $9.74 \mathrm{E}-05$ & 5.7 \\
\hline $4 \mathrm{H}-4 \mathrm{~W}, 75-77$ & 25.16 & -44.3 & 74.9 & & & $1.33 \mathrm{E}-04$ & 5.9 \\
\hline $4 \mathrm{H}-5 \mathrm{~W}, 75-77$ & 26.66 & 237.3 & -4.3 & & & $5.48 \mathrm{E}-05$ & 11.3 \\
\hline $4 \mathrm{H}-6 \mathrm{~W}, 75-77$ & 28.16 & 149.2 & 39.2 & & & $2.85 \mathrm{E}-04$ & 6.9 \\
\hline $4 \mathrm{H}-7 \mathrm{~W}, 35-37$ & 29.26 & 148.5 & -10.2 & & & $7.03 \mathrm{E}-05$ & 18.1 \\
\hline $5 \mathrm{H}-1 \mathrm{~W}, 74-76$ & 30.15 & 141.7 & 30.7 & & & $5.65 \mathrm{E}-05$ & 11.5 \\
\hline $5 \mathrm{H}-2 \mathrm{~W}, 74-76$ & 31.65 & 208.5 & 13.7 & & & $5.58 \mathrm{E}-05$ & 4.5 \\
\hline $5 \mathrm{H}-4 \mathrm{~W}, 74-76$ & 34.65 & 50.8 & 8.1 & & & $2.85 \mathrm{E}-05$ & 28.3 \\
\hline $5 \mathrm{H}-6 \mathrm{~W}, 74-76$ & 37.65 & -2.0 & -12.0 & & & $1.12 \mathrm{E}-04$ & 13.5 \\
\hline $6 \mathrm{H}-2 \mathrm{~W}, 74-76$ & 41.15 & -7.6 & 0.5 & & & $1.61 \mathrm{E}-04$ & 10.7 \\
\hline $6 \mathrm{H}-4 \mathrm{~W}, 74-76$ & 44.15 & 21.2 & -42.3 & & & $1.05 \mathrm{E}-04$ & 14.3 \\
\hline $6 \mathrm{H}-6 \mathrm{~W}, 74-76$ & 47.15 & 268.2 & -20.0 & & & $1.28 \mathrm{E}-04$ & 6.3 \\
\hline $7 \mathrm{H}-2 \mathrm{~W}, 74-76$ & 50.65 & -56.2 & 5.2 & & & $6.53 \mathrm{E}-05$ & 3.7 \\
\hline 7H-4W, 74-76 & 53.65 & 116.4 & 68.0 & & & $1.09 \mathrm{E}-04$ & 11.3 \\
\hline $7 \mathrm{H}-5 \mathrm{~W}, 74-76$ & 55.16 & -78.4 & -41.6 & & & $3.15 \mathrm{E}-05$ & 17.9 \\
\hline $7 \mathrm{H}-6 \mathrm{~W}, 70-72$ & 56.62 & 151.5 & -75.3 & & & $9.04 \mathrm{E}-05$ & 6.7 \\
\hline 7H-7W, 31-33 & 57.73 & 254.4 & -41.8 & & & $1.27 \mathrm{E}-04$ & 3.8 \\
\hline $8 \mathrm{H}-1 \mathrm{~W}, 74-76$ & 58.65 & 196.0 & 42.3 & & & $9.24 \mathrm{E}-05$ & 5.2 \\
\hline $8 \mathrm{H}-2 \mathrm{~W}, 74-76$ & 60.15 & 0.8 & 19.1 & & & $1.16 \mathrm{E}-04$ & 7.6 \\
\hline $8 \mathrm{H}-4 \mathrm{~W}, 74-76$ & 63.19 & 177.8 & -42.0 & & & $2.32 \mathrm{E}-04$ & 6.4 \\
\hline $8 \mathrm{H}-5 \mathrm{~W}, 74-76$ & 64.70 & 48.4 & 50.1 & & & $1.28 \mathrm{E}-04$ & 8.6 \\
\hline $8 \mathrm{H}-6 \mathrm{~W}, 74-76$ & 66.21 & 220.2 & 0.7 & & & $1.35 \mathrm{E}-04$ & 4.1 \\
\hline $9 \mathrm{H}-2 \mathrm{~W}, 74-76$ & 68.39 & 199.5 & -44.5 & & & $2.66 \mathrm{E}-04$ & 5.3 \\
\hline $9 \mathrm{H}-3 \mathrm{~W}, 74-76$ & 69.89 & 189.6 & -65.4 & & & $2.69 \mathrm{E}-04$ & 6.5 \\
\hline $9 \mathrm{H}-4 \mathrm{~W}, 74-76$ & 71.39 & 127.8 & 26.7 & & & $1.26 \mathrm{E}-04$ & 10.8 \\
\hline $9 \mathrm{H}-5 \mathrm{~W}, 74-76$ & 72.89 & 229.3 & -40.9 & & & $1.58 \mathrm{E}-04$ & 9.9 \\
\hline $9 \mathrm{H}-6 \mathrm{~W}, 74-76$ & 74.39 & 229.1 & 23.0 & & & $7.03 \mathrm{E}-05$ & 12.5 \\
\hline $9 \mathrm{H}-7 \mathrm{~W}, 45-47$ & 75.60 & 197.2 & -42.0 & & & $3.49 \mathrm{E}-05$ & 24.6 \\
\hline $9 \mathrm{H}-8 \mathrm{~W}, 25-27$ & 76.41 & -55.8 & -32.6 & & & 4.47E-05 & 16.5 \\
\hline $10 \mathrm{H}-2 \mathrm{~W}, 74-76$ & 79.15 & 237.3 & 3.1 & & & $1.42 \mathrm{E}-04$ & 8.8 \\
\hline $10 \mathrm{H}-4 \mathrm{~W}, 74-76$ & 82.15 & -12.7 & 41.7 & & & $7.89 \mathrm{E}-05$ & 16.7 \\
\hline $10 \mathrm{H}-6 \mathrm{~W}, 68-70$ & 85.09 & -2.0 & 48.9 & & & 4.46E-04 & 3.4 \\
\hline $11 \mathrm{H}-1 \mathrm{~W}, 31-33$ & 86.72 & 159.1 & 85.5 & & & $5.50 \mathrm{E}-04$ & 2.8 \\
\hline $11 \mathrm{H}-2 \mathrm{~W}, 74-76$ & 88.65 & -69.8 & 5.6 & & & $1.03 \mathrm{E}-04$ & 9.8 \\
\hline $11 \mathrm{H}-3 \mathrm{~W}, 70-72$ & 90.11 & -72.0 & 19.2 & & & $2.56 \mathrm{E}-04$ & 8.5 \\
\hline $11 \mathrm{H}-4 \mathrm{~W}, 74-76$ & 91.45 & 253.0 & 7.7 & & & $1.84 \mathrm{E}-04$ & 12.3 \\
\hline $11 \mathrm{H}-5 \mathrm{~W}, 74-76$ & 92.95 & 76.9 & 16.5 & & & $6.47 \mathrm{E}-05$ & 8.3 \\
\hline $11 \mathrm{H}-6 \mathrm{~W}, 70-72$ & 94.41 & 199.8 & 7.6 & & & $2.58 \mathrm{E}-04$ & 5.8 \\
\hline $11 \mathrm{H}-7 \mathrm{~W}, 32-34$ & 95.53 & 194.7 & 6.9 & & & $3.19 \mathrm{E}-04$ & 6.3 \\
\hline $12 \mathrm{H}-1 \mathrm{~W}, 74-76$ & 96.65 & 20.0 & -20.8 & & & $6.97 \mathrm{E}-05$ & 13.7 \\
\hline $12 \mathrm{H}-2 \mathrm{~W}, 74-76$ & 98.15 & 132.8 & -23.4 & & & 3.67E-04 & 5.2 \\
\hline $12 \mathrm{H}-3 \mathrm{~W}, 74-76$ & 99.65 & 31.9 & -45.7 & & & $1.81 \mathrm{E}-04$ & 7.3 \\
\hline $12 \mathrm{H}-4 \mathrm{~W}, 74-76$ & 101.15 & 105.0 & -20.8 & & & $6.22 \mathrm{E}-04$ & 3.4 \\
\hline $12 \mathrm{H}-7 \mathrm{~W}, 27-29$ & 104.70 & 186.1 & -25.7 & & & $1.78 \mathrm{E}-04$ & 4.2 \\
\hline $13 \mathrm{H}-2 \mathrm{~W}, 75-77$ & 107.66 & 117.0 & -24.0 & & & $1.22 \mathrm{E}-04$ & 4.1 \\
\hline $13 \mathrm{H}-4 \mathrm{~W}, 75-77$ & 110.67 & 105.8 & -2.1 & & & $6.45 \mathrm{E}-05$ & 16.4 \\
\hline $13 \mathrm{H}-5 \mathrm{~W}, 75-77$ & 112.18 & 142.2 & 11.3 & & & $7.20 \mathrm{E}-05$ & 13.2 \\
\hline $13 \mathrm{H}-6 \mathrm{~W}, 75-77$ & 113.70 & 102.3 & -15.8 & & & $6.76 \mathrm{E}-05$ & 17.0 \\
\hline $13 \mathrm{H}-7 \mathrm{~W}, 29-31$ & 114.74 & 148.6 & 12.4 & & & $9.07 \mathrm{E}-05$ & 9.4 \\
\hline $14 \mathrm{H}-1 \mathrm{~W}, 75-77$ & 115.66 & 147.3 & 2.3 & & & $5.63 \mathrm{E}-05$ & 11.5 \\
\hline $14 \mathrm{H}-4 \mathrm{~W}, 75-77$ & 120.16 & 16.9 & -84.7 & & & $2.09 \mathrm{E}-05$ & 35.1 \\
\hline $14 \mathrm{H}-6 \mathrm{~W}, 75-77$ & 123.16 & 126.0 & 3.7 & & & $5.25 \mathrm{E}-05$ & 14.9 \\
\hline $15 \mathrm{H}-1 \mathrm{~W}, 75-77$ & 125.16 & 161.1 & 9.7 & & & $5.06 \mathrm{E}-05$ & 19.6 \\
\hline $15 \mathrm{H}-2 \mathrm{~W}, 75-77$ & 126.58 & 198.7 & -36.4 & & & $1.19 \mathrm{E}-04$ & 13.3 \\
\hline $15 \mathrm{H}-3 \mathrm{~W}, 75-77$ & 128.06 & 130.6 & -48.5 & & & $5.35 \mathrm{E}-05$ & 15.3 \\
\hline $15 \mathrm{H}-4 \mathrm{~W}, 75-77$ & 129.52 & 35.2 & 29.3 & & & $8.37 \mathrm{E}-05$ & 10.2 \\
\hline
\end{tabular}


Table T11 (continued).

\begin{tabular}{|c|c|c|c|c|c|c|c|}
\hline $\begin{array}{l}\text { Core, section, } \\
\text { interval }(\mathrm{cm})\end{array}$ & $\begin{array}{l}\text { Depth } \\
\text { (mbsf) }\end{array}$ & $\begin{array}{c}\text { Declination } \\
20 \mathrm{mT} \text { or PCA } \\
\left({ }^{\circ}\right)\end{array}$ & $\begin{array}{c}\text { Inclination } \\
20 \mathrm{mT} \text { or PCA } \\
\left(^{\circ}\right)\end{array}$ & $\begin{array}{c}\text { PCA } \\
\text { MAD } \\
\left(^{\circ}\right)\end{array}$ & $\begin{array}{c}\mathrm{PCA} \\
\text { range } \\
(\mathrm{mT})\end{array}$ & $\begin{array}{l}\text { NRM } \\
20 \mathrm{mT} \\
(\mathrm{A} / \mathrm{m})\end{array}$ & $\begin{array}{c}\text { Measurement } \\
\text { error } \\
(\%)\end{array}$ \\
\hline $16 \mathrm{H}-1 \mathrm{~W}, 75-77$ & 134.36 & 52.4 & -1.6 & & & $7.36 \mathrm{E}-05$ & 13.6 \\
\hline $16 \mathrm{H}-2 \mathrm{~W}, 75-77$ & 135.86 & -17.0 & 58.2 & & & $3.95 \mathrm{E}-05$ & 16.6 \\
\hline $16 \mathrm{H}-3 \mathrm{~W}, 75-77$ & 137.36 & 36.7 & 41.9 & & & $9.96 \mathrm{E}-05$ & 2.8 \\
\hline $16 \mathrm{H}-5 \mathrm{~W}, 75-77$ & 140.36 & 13.4 & 21.8 & & & $1.62 \mathrm{E}-04$ & 4.2 \\
\hline $17 \mathrm{H}-1 \mathrm{~W}, 75-77$ & 143.86 & 18.9 & 55.8 & & & $7.32 \mathrm{E}-03$ & 3.4 \\
\hline $17 \mathrm{H}-3 \mathrm{~W}, 70-72$ & 146.81 & 181.0 & -55.5 & 5.9 & $20-60$ & $5.45 \mathrm{E}-03$ & 4.0 \\
\hline $17 \mathrm{H}-5 \mathrm{~W}, 75-77$ & 149.86 & 142.6 & -46.2 & & & $3.83 \mathrm{E}-03$ & 5.1 \\
\hline $18 \mathrm{H}-4 \mathrm{~W}, 75-77$ & 157.86 & 221.2 & 6.5 & & & $3.20 \mathrm{E}-03$ & 5.4 \\
\hline $18 \mathrm{H}-6 \mathrm{~W}, 75-77$ & 160.86 & 243.6 & 44.7 & & & $2.81 \mathrm{E}-03$ & 3.6 \\
\hline $19 \mathrm{H}-3 \mathrm{~W}, 70-72$ & 165.81 & 153.1 & -2.9 & & & $4.43 \mathrm{E}-03$ & 5.8 \\
\hline $19 \mathrm{H}-5 \mathrm{~W}, 75-77$ & 168.86 & 125.9 & 3.8 & & & $2.48 \mathrm{E}-03$ & 4.1 \\
\hline $19 \mathrm{H}-6 \mathrm{~W}, 20-22$ & 169.81 & 147.8 & -40.8 & & & $5.06 \mathrm{E}-03$ & 4.4 \\
\hline $20 \mathrm{H}-1 \mathrm{~W}, 74-76$ & 172.35 & 195.6 & 5.6 & & & $2.72 \mathrm{E}-03$ & 6.9 \\
\hline $20 \mathrm{H}-3 \mathrm{~W}, 74-76$ & 175.35 & -36.5 & 26.8 & & & $6.24 \mathrm{E}-03$ & 5.3 \\
\hline $23 X-2 W, 75-77$ & 198.86 & 152.2 & 28.9 & & & $8.52 \mathrm{E}-03$ & 6.1 \\
\hline $23 X-4 W, 128-130$ & 202.39 & 216.5 & 6.5 & 3.4 & $10-60$ & $2.91 \mathrm{E}-02$ & 3.5 \\
\hline $23 X-6 W, 86-88$ & 204.97 & 208.7 & 51.2 & & & $1.21 \mathrm{E}-02$ & 3.2 \\
\hline $24 X-1 W, 64-66$ & 206.85 & -56.5 & 64.9 & & & $1.10 \mathrm{E}-02$ & 4.0 \\
\hline $24 X-3 W, 70-72$ & 209.91 & 42.8 & 31.1 & 2.5 & $30-60$ & $1.88 \mathrm{E}-02$ & 3.2 \\
\hline $25 X-1 W, 131-133$ & 217.12 & -35.6 & 23.7 & 8.7 & $10-60$ & $8.15 E-03$ & 5.9 \\
\hline $25 \mathrm{X}-2 \mathrm{~W}, 122-124$ & 218.53 & 179.3 & -1.3 & & & $6.88 \mathrm{E}-03$ & 5.0 \\
\hline $25 X-3 W, 34-36$ & 219.15 & -82.2 & -46.6 & & & $4.95 \mathrm{E}-03$ & 5.9 \\
\hline $25 X-4 W, 116-118$ & 221.47 & 84.9 & -1.6 & & & $1.30 \mathrm{E}-03$ & 4.4 \\
\hline $25 X-5 W, 32-34$ & 222.13 & 72.0 & 39.4 & & & $2.72 \mathrm{E}-03$ & 3.8 \\
\hline $26 X-2 W, 81-83$ & 227.72 & 139.3 & 32.5 & & & $9.45 \mathrm{E}-03$ & 6.3 \\
\hline $26 X-4 W, 78-80$ & 230.69 & 111.1 & 39.8 & & & $1.50 \mathrm{E}-02$ & 5.5 \\
\hline $26 X-6 W, 85-87$ & 233.76 & 75.9 & 41.1 & & & $7.79 \mathrm{E}-03$ & 3.8 \\
\hline $27 X-2 W, 18-20$ & 236.22 & -6.8 & 48.3 & & & $6.22 \mathrm{E}-03$ & 4.5 \\
\hline 27X-4W, 117-119 & 239.30 & 220.7 & 35.1 & 8.0 & $10-60$ & $6.43 \mathrm{E}-03$ & 3.3 \\
\hline $27 X-6 W, 32-34$ & 241.44 & -83.5 & 33.2 & & & $4.35 \mathrm{E}-03$ & 5.8 \\
\hline $28 X-2 W, 65-67$ & 246.76 & 94.2 & 2.5 & & & $9.63 \mathrm{E}-03$ & 6.0 \\
\hline $28 X-4 W, 50-52$ & 249.61 & 188.5 & 18.2 & 9.2 & $10-60$ & $5.85 \mathrm{E}-03$ & 4.5 \\
\hline $28 X-6 W, 37-39$ & 252.48 & -15.1 & 20.5 & & & $5.45 \mathrm{E}-03$ & 5.5 \\
\hline
\end{tabular}

Declinations for Cores $2 \mathrm{H}$ to $20 \mathrm{H}$ are in geographic coordinates. $\mathrm{PCA}=$ principal component analysis, $\mathrm{MAD}=$ maximum angle of deviation, $\mathrm{NRM}$ $=$ natural remanent magnetism. 
Table T12. Magnetostratigraphic tie points, Site U1411.

\begin{tabular}{|c|c|c|c|c|c|c|c|c|c|c|c|}
\hline \multirow[b]{3}{*}{ Chron boundary } & \multirow[b]{3}{*}{$\begin{array}{l}\text { Age } \\
(\mathrm{Ma})\end{array}$} & \multicolumn{5}{|c|}{ Hole U1411B } & \multicolumn{5}{|c|}{ Hole U1411C } \\
\hline & & \multicolumn{2}{|l|}{ Top } & \multicolumn{2}{|c|}{ Bottom } & \multirow[b]{2}{*}{$\begin{array}{c}\text { Midpoint } \\
\text { (mbsf) }\end{array}$} & \multicolumn{2}{|c|}{ Top } & \multicolumn{2}{|l|}{ Bottom } & \multirow[b]{2}{*}{$\begin{array}{c}\text { Midpoint } \\
\text { (mbsf) }\end{array}$} \\
\hline & & $\begin{array}{l}\text { Core, section, } \\
\text { interval }(\mathrm{cm})\end{array}$ & $\begin{array}{l}\text { Depth } \\
\text { (mbsf) }\end{array}$ & $\begin{array}{l}\text { Core, section, } \\
\text { interval (cm) }\end{array}$ & $\begin{array}{l}\text { Depth } \\
\text { (mbsf) }\end{array}$ & & $\begin{array}{l}\text { Core, section, } \\
\text { interval }(\mathrm{cm})\end{array}$ & $\begin{array}{l}\text { Depth } \\
\text { (mbsf) }\end{array}$ & $\begin{array}{l}\text { Core, section, } \\
\text { interval }(\mathrm{cm})\end{array}$ & $\begin{array}{l}\text { Depth } \\
\text { (mbsf) }\end{array}$ & \\
\hline C1n (Brunhes)/C1r.1r (Matuyama) & 0.781 & $\begin{array}{r}342-\mathrm{U} 1411 \mathrm{~B}- \\
2 \mathrm{H}-5,70.0\end{array}$ & 7.60 & $\begin{array}{r}342-\mathrm{U} 1411 \mathrm{~B}- \\
2 \mathrm{H}-5,100.0\end{array}$ & 7.90 & 7.75 & $\begin{array}{c}342-\mathrm{U} 1411 \mathrm{C}- \\
2 \mathrm{H}-1,45.0\end{array}$ & 3.65 & $\begin{array}{c}342-\mathrm{U} 1411 \mathrm{C}- \\
2 \mathrm{H}-1,62.5\end{array}$ & 3.83 & 3.74 \\
\hline C1r.1r (Matuyama)/C1r.1n (Jaramillo) & 0.988 & $2 \mathrm{H}-6,57.5$ & 8.98 & $2 \mathrm{H}-6,77.5$ & 9.18 & 9.08 & $2 \mathrm{H}-2,27.5$ & 4.98 & $2 \mathrm{H}-2,37.5$ & 5.08 & 5.03 \\
\hline C1r.1n (Jaramillo)/C1r.2r & 1.072 & $2 \mathrm{H}-6,120.0$ & 9.60 & $2 \mathrm{H}-6,130.0$ & 9.70 & 9.65 & $2 \mathrm{H}-2,52.5$ & 5.23 & $2 \mathrm{H}-2,60.0$ & 5.30 & 5.26 \\
\hline $\mathrm{C} 1 \mathrm{r} .2 \mathrm{r} / \mathrm{C} 1 \mathrm{r} .2 \mathrm{n}$ (Cobb Mountain) & 1.173 & $2 \mathrm{H}-7,22.5$ & 10.13 & $2 \mathrm{H}-7,30.0$ & 10.20 & 10.17 & $2 \mathrm{H}-3,55.0$ & 6.75 & $2 \mathrm{H}-3,62.5$ & 6.83 & 6.79 \\
\hline C1r.2n (Cobb Mountain)/C1r.3r & 1.185 & $2 \mathrm{H}-7,40.0$ & 10.30 & $2 \mathrm{H}-7,52.5$ & 10.43 & 10.37 & $2 \mathrm{H}-3,72.5$ & 6.93 & $2 \mathrm{H}-3,77.5$ & 6.98 & 6.95 \\
\hline $\mathrm{C} 8 \mathrm{n} .2 \mathrm{n} / \mathrm{C} 8 \mathrm{r}$ & 25.987 & $4 \mathrm{H}-4,76.0$ & 25.16 & $4 \mathrm{H}-5,76.0$ & 26.66 & 25.91 & $\mathrm{NI}$ & $\mathrm{NI}$ & $\mathrm{NI}$ & $\mathrm{NI}$ & $\mathrm{NI}$ \\
\hline $\mathrm{C} 8 \mathrm{r} / \mathrm{C} 9 \mathrm{n}$ & 26.420 & $5 \mathrm{H}-2,75.0$ & 31.65 & $5 \mathrm{H}-3,20.0$ & 32.60 & 32.13 & $\mathrm{NI}$ & $\mathrm{NI}$ & $\mathrm{NI}$ & $\mathrm{NI}$ & $\mathrm{NI}$ \\
\hline $\mathrm{C} 9 \mathrm{n} / \mathrm{C9r}$ & 27.439 & $7 \mathrm{H}-4,75.0$ & 53.65 & $7 \mathrm{H}-5,75.0$ & 55.16 & 54.41 & $\mathrm{NI}$ & $\mathrm{NI}$ & $\mathrm{NI}$ & $\mathrm{NI}$ & $\mathrm{NI}$ \\
\hline C9r/C10n.1n & 27.859 & $8 \mathrm{H}-1,75.0$ & 58.65 & $8 \mathrm{H}-2,15.0$ & 59.55 & 59.10 & $\mathrm{NI}$ & $\mathrm{NI}$ & $\mathrm{NI}$ & $\mathrm{NI}$ & $\mathrm{NI}$ \\
\hline C10n.1n/C10n.1r & 28.087 & $8 \mathrm{H}-3,122.5$ & 62.14 & $8 \mathrm{H}-3,137.5$ & 62.26 & 62.20 & $\mathrm{NI}$ & $\mathrm{NI}$ & $\mathrm{NI}$ & $\mathrm{NI}$ & $\mathrm{NI}$ \\
\hline C10n.1r/C10n.2n & 28.141 & $8 \mathrm{H}-4,95.0$ & 63.39 & $8 \mathrm{H}-4,105.0$ & 63.49 & 63.44 & $\mathrm{NI}$ & $\mathrm{NI}$ & $\mathrm{NI}$ & $\mathrm{NI}$ & $\mathrm{NI}$ \\
\hline $\mathrm{C} 10 \mathrm{n} \cdot 2 \mathrm{n} / \mathrm{C} 10 \mathrm{r}$ & 28.278 & $8 \mathrm{H}-5,130.0$ & 65.25 & $8 \mathrm{H}-6,10.0$ & 65.56 & 65.41 & $\mathrm{NI}$ & $\mathrm{NI}$ & $\mathrm{NI}$ & $\mathrm{NI}$ & $\mathrm{NI}$ \\
\hline C10r/C11n.1n & 29.183 & $\mathrm{NI}$ & $\mathrm{NI}$ & $\mathrm{NI}$ & $\mathrm{NI}$ & $\mathrm{NI}$ & $\mathrm{NI}$ & $\mathrm{NI}$ & $\mathrm{NI}$ & $\mathrm{NI}$ & $\mathrm{NI}$ \\
\hline $\mathrm{C} 11 \mathrm{n} .1 \mathrm{n} / \mathrm{C} 11 \mathrm{n} .1 \mathrm{r}$ & 29.477 & $\mathrm{NI}$ & $\mathrm{NI}$ & $\mathrm{NI}$ & $\mathrm{NI}$ & $\mathrm{NI}$ & $\mathrm{NI}$ & $\mathrm{NI}$ & $\mathrm{NI}$ & $\mathrm{NI}$ & $\mathrm{NI}$ \\
\hline $\mathrm{C} 11 \mathrm{n} .1 \mathrm{r} / \mathrm{C} 11 \mathrm{n} .2 \mathrm{n}$ & 29.527 & $\mathrm{NI}$ & $\mathrm{NI}$ & $\mathrm{NI}$ & $\mathrm{NI}$ & $\mathrm{NI}$ & $\mathrm{NI}$ & $\mathrm{NI}$ & $\mathrm{NI}$ & $\mathrm{NI}$ & $\mathrm{NI}$ \\
\hline $\mathrm{C} 11 \mathrm{n} \cdot 2 \mathrm{n} / \mathrm{C} 11 \mathrm{r}$ & 29.970 & $10 \mathrm{H}-4,110.0$ & 82.50 & $10 \mathrm{H}-4,127.5$ & 82.68 & 82.59 & $\mathrm{NI}$ & $\mathrm{NI}$ & $\mathrm{NI}$ & $\mathrm{NI}$ & $\mathrm{NI}$ \\
\hline $\mathrm{C} 11 \mathrm{r} / \mathrm{C} 12 \mathrm{n}$ & 30.591 & $\mathrm{NI}$ & $\mathrm{NI}$ & $\mathrm{NI}$ & $\mathrm{NI}$ & $\mathrm{NI}$ & $\mathrm{NI}$ & $\mathrm{NI}$ & $\mathrm{NI}$ & $\mathrm{NI}$ & $\mathrm{NI}$ \\
\hline $\mathrm{C} 12 \mathrm{n} / \mathrm{C} 12 \mathrm{r}$ & 31.034 & $\mathrm{NI}$ & $\mathrm{NI}$ & $\mathrm{NI}$ & $\mathrm{NI}$ & $\mathrm{NI}$ & $\mathrm{NI}$ & $\mathrm{NI}$ & $\mathrm{NI}$ & $\mathrm{NI}$ & $\mathrm{NI}$ \\
\hline $\mathrm{C} 12 \mathrm{r} / \mathrm{C} 13 \mathrm{n}$ & 33.157 & $15 \mathrm{H}-3,76.0$ & 128.06 & $15 \mathrm{H}-4,76.0$ & 129.52 & 128.79 & $7 \mathrm{H}-1,110.0$ & 126.6 & $7 \mathrm{H}-2,67.5$ & 127.68 & 127.14 \\
\hline $\mathrm{C} 13 \mathrm{n} / \mathrm{C} 13 \mathrm{r}$ & 33.705 & $17 \mathrm{H}-1,100.0$ & 144.10 & $17 \mathrm{H}-1,110.0$ & 144.20 & 144.15 & $8 \mathrm{H}-5,140.0$ & 142.4 & $8 \mathrm{H}-6,10.0$ & 142.6 & 142.50 \\
\hline C13r,crypto-1,top & & $18 \mathrm{H}-1,60.0$ & 153.20 & $18 \mathrm{H}-1,70.0$ & 153.30 & 153.25 & $\mathrm{NI}$ & $\mathrm{NI}$ & $\mathrm{NI}$ & $\mathrm{NI}$ & $\mathrm{NI}$ \\
\hline C13r,crypto-1, bottom & & $18 \mathrm{H}-1,115.0$ & 153.75 & $18 \mathrm{H}-1,127.5$ & 153.88 & 153.82 & $\mathrm{NI}$ & $\mathrm{NI}$ & $\mathrm{NI}$ & $\mathrm{NI}$ & $\mathrm{NI}$ \\
\hline C13r,crypto-2,top & & $18 \mathrm{H}-5,80.0$ & 159.40 & $18 \mathrm{H}-5,105.0$ & 159.65 & 159.53 & $\mathrm{NI}$ & $\mathrm{NI}$ & $\mathrm{NI}$ & $\mathrm{NI}$ & $\mathrm{NI}$ \\
\hline C13r,crypto-2,bottom & & $19 \mathrm{H}-1,10.0$ & 162.20 & $19 \mathrm{H}-1,27.5$ & 162.38 & 162.29 & $\mathrm{NI}$ & $\mathrm{NI}$ & $\mathrm{NI}$ & $\mathrm{NI}$ & $\mathrm{NI}$ \\
\hline C13r,crypto-3,top & & $19 \mathrm{H}-4,112.5$ & 167.73 & $19 \mathrm{H}-4,130.0$ & 167.90 & 167.82 & $\mathrm{NI}$ & $\mathrm{NI}$ & $\mathrm{NI}$ & $\mathrm{NI}$ & $\mathrm{NI}$ \\
\hline C13r,crypto-3, bottom & & $19 \mathrm{H}-5,137.5$ & 169.48 & $19 \mathrm{H}-6,12.5$ & 169.73 & 169.61 & $\mathrm{NI}$ & $\mathrm{NI}$ & $\mathrm{NI}$ & $\mathrm{NI}$ & $\mathrm{NI}$ \\
\hline $\mathrm{C} 13 \mathrm{r} / \mathrm{C} 15 \mathrm{n}$ & 34.999 & $20 \mathrm{H}-1,130.0$ & 172.90 & $20 \mathrm{H}-1,145.0$ & 173.05 & 172.98 & $\mathrm{NI}$ & $\mathrm{NI}$ & $\mathrm{NI}$ & $\mathrm{NI}$ & $\mathrm{NI}$ \\
\hline
\end{tabular}

Ages from Gradstein et al. (2012). NI = not identified. 
Table T13. Datum tie points, Hole U1411B.

\begin{tabular}{|c|c|c|c|c|c|c|c|c|c|}
\hline $\begin{array}{l}\text { Datum } \\
\text { tie point }\end{array}$ & Datum & Datum type & Zone & $\begin{array}{l}\text { Age } \\
(\mathrm{Ma})\end{array}$ & $\begin{array}{l}\text { Midpoint } \\
\text { depth } \\
\text { (mbsf) }\end{array}$ & $\begin{array}{l}\text { Distance } \\
\text { (m) }\end{array}$ & $\begin{array}{l}\text { Duration } \\
\text { (Ma) }\end{array}$ & $\begin{array}{c}\text { LSR } \\
(\mathrm{cm} / \mathrm{k} . \mathrm{y} .)\end{array}$ & Notes \\
\hline D01 & T Pseudoemiliania lacunosa & Calcareous nannofossil & NN20 & 0.44 & 0.89 & 0.89 & 0.44 & & \multirow{3}{*}{$\begin{array}{r}\text { Average rate }= \\
1.27 \mathrm{~cm} / \mathrm{k} . \mathrm{y} .\end{array}$} \\
\hline D02 & C1n (Brunhes)/C1r.1r (Matuyama) & Chron boundary & & 0.78 & 7.75 & 6.86 & 0.34 & 2.02 & \\
\hline D03 & C1r.2n (Cobb Mountain)/C1r.3r & Chron boundary & & 1.19 & 10.37 & 2.62 & 0.40 & 0.66 & \\
\hline D04 & T Triquetrorhabdulus carinatus & Calcareous nannofossil & NN3 & 18.28 & 18.00 & 8.44 & 17.10 & 0.05 & \multirow{2}{*}{$\begin{array}{r}\text { Average rate }= \\
0.06 \mathrm{~cm} / \mathrm{k} . \mathrm{y} .\end{array}$} \\
\hline D05 & $\mathrm{C} 8 \mathrm{n} \cdot 2 \mathrm{n} / \mathrm{C} 8 \mathrm{r}$ & Chron boundary & & 25.99 & 25.91 & 7.11 & 7.71 & 0.09 & \\
\hline D06 & $\mathrm{C} 8 \mathrm{r} / \mathrm{C} 9 \mathrm{n}$ & Chron boundary & & 26.42 & 32.13 & 6.22 & 0.43 & 1.45 & \multirow{2}{*}{$\begin{array}{r}\text { Average rate }= \\
1.96 \mathrm{~cm} / \mathrm{k} . \mathrm{y}\end{array}$} \\
\hline D07 & $\mathrm{C} 9 \mathrm{n} / \mathrm{C} 9 \mathrm{r}$ & Chron boundary & & 27.44 & 54.41 & 22.28 & 1.02 & 2.18 & \\
\hline D08 & $\mathrm{C} 10 \mathrm{n} .2 \mathrm{n} / \mathrm{C} 10 \mathrm{r}$ & Chron boundary & & 28.28 & 65.41 & 11.00 & 0.84 & 1.31 & \multirow{2}{*}{$\begin{array}{r}\text { Average rate }= \\
1.11 \mathrm{~cm} / \mathrm{k} . \mathrm{y} .\end{array}$} \\
\hline D09 & $\mathrm{C} 11 \mathrm{n} .2 \mathrm{n} / \mathrm{C} 11 \mathrm{r}$ & Chron boundary & & 29.97 & 82.59 & 17.19 & 1.69 & 1.02 & \\
\hline D10 & T Turborotalia ampliapertura & Planktonic foraminifer & $\mathrm{O} 3 / \mathrm{O} 2$ & 30.28 & 91.42 & 8.83 & 0.31 & 2.85 & 2.85 \\
\hline D11 & Inferred hiatus & Decreed (KoT, 28-07-12) & & 31.00 & 91.42 & 0.00 & 0.72 & 0.00 & Hiatus \\
\hline D12 & $\mathrm{T}$ Isthmolithus recurvus & Calcareous nannofossil & & 32.49 & 103.74 & 12.32 & 1.49 & 0.83 & 0.83 \\
\hline D13 & $\mathrm{C} 12 \mathrm{r} / \mathrm{C} 13 \mathrm{n}$ & Chron boundary & & 33.16 & 128.79 & 25.05 & 0.67 & 3.74 & \multirow{6}{*}{$\begin{array}{r}\text { Average rate }= \\
2.74 \mathrm{~cm} / \mathrm{k} . \mathrm{y}\end{array}$} \\
\hline D14 & $\mathrm{C} 13 n / C 13 r$ & Chron boundary & & 33.71 & 144.15 & 15.36 & 0.55 & 2.79 & \\
\hline D15 & T Turborotalia cerroazulensis & Planktonic foraminifer & Within E16 & 34.03 & 160.46 & 16.31 & 0.33 & 4.94 & \\
\hline D16 & $\mathrm{C} 13 \mathrm{r} / \mathrm{C} 15 \mathrm{n}$ & Chron boundary & & 35.00 & 172.98 & 12.52 & 0.97 & 1.29 & \\
\hline D17 & T Globigerinatheka semiinvoluta & Planktonic foraminifer & E15/E14 & 36.18 & 208.90 & 35.92 & 1.18 & 3.04 & \\
\hline D18 & T Chiasmolithus grandis & Calcareous nannofossil & & 37.98 & 253.15 & 45.11 & 1.80 & 2.51 & \\
\hline
\end{tabular}

LSR = linear sedimentation rate. $\mathrm{T}=$ top. 
Table T14. Carbonate content and accumulation rates, Site U1411. (Continued on next two pages.)

\begin{tabular}{|c|c|c|c|c|c|c|}
\hline $\begin{array}{l}\text { Age } \\
(\mathrm{Ma})\end{array}$ & $\begin{array}{c}\text { LSR } \\
(\mathrm{cm} / \mathrm{k} . \mathrm{y} .)\end{array}$ & $\begin{array}{l}\text { Dry density } \\
\left(\mathrm{g} / \mathrm{cm}^{3}\right)\end{array}$ & $\begin{array}{l}\mathrm{CaCO}_{3} \\
\text { (wt\%) }\end{array}$ & $\begin{array}{c}\text { MAR } \\
\left(\mathrm{g} / \mathrm{cm}^{2} / \mathrm{k} . \mathrm{y} .\right)\end{array}$ & $\begin{array}{c}\text { CAR } \\
\left(\mathrm{g} / \mathrm{cm}^{2} / \mathrm{k} . \mathrm{y} .\right)\end{array}$ & $\begin{array}{c}\text { nCAR } \\
\left(\mathrm{g} / \mathrm{cm}^{2} / \mathrm{k} . \mathrm{y} .\right)\end{array}$ \\
\hline 0.6 & 2.01 & 0.88 & 37.35 & 1.78 & 0.66 & 1.11 \\
\hline 0.8 & 0.65 & 0.80 & 34.95 & 0.52 & 0.18 & 0.34 \\
\hline 1.0 & 0.65 & 0.96 & 28.36 & 0.63 & 0.18 & 0.45 \\
\hline 1.2 & 0.05 & 1.18 & 11.05 & 0.06 & 0.01 & 0.05 \\
\hline 1.4 & 0.05 & 1.21 & 9.44 & 0.06 & 0.01 & 0.05 \\
\hline 1.6 & 0.05 & 1.23 & 11.36 & 0.06 & 0.01 & 0.05 \\
\hline 1.8 & 0.05 & 1.26 & 13.36 & 0.06 & 0.01 & 0.05 \\
\hline 2.0 & 0.05 & 1.28 & 15.15 & 0.06 & 0.01 & 0.05 \\
\hline 2.2 & 0.05 & 1.29 & 15.88 & 0.06 & 0.01 & 0.05 \\
\hline 2.4 & 0.05 & 1.29 & 16.04 & 0.06 & 0.01 & 0.05 \\
\hline 2.6 & 0.05 & 1.29 & 16.13 & 0.06 & 0.01 & 0.05 \\
\hline 2.8 & 0.05 & 1.30 & 16.23 & 0.06 & 0.01 & 0.05 \\
\hline 3.0 & 0.05 & 1.30 & 16.32 & 0.06 & 0.01 & 0.05 \\
\hline 3.2 & 0.05 & 1.30 & 16.41 & 0.06 & 0.01 & 0.05 \\
\hline 3.4 & 0.05 & 1.30 & 16.51 & 0.06 & 0.01 & 0.05 \\
\hline 3.6 & 0.05 & 1.30 & 16.60 & 0.06 & 0.01 & 0.05 \\
\hline 3.8 & 0.05 & 1.31 & 16.69 & 0.06 & 0.01 & 0.05 \\
\hline 4.0 & 0.05 & 1.31 & 16.78 & 0.07 & 0.01 & 0.05 \\
\hline 4.2 & 0.05 & 1.31 & 16.88 & 0.07 & 0.01 & 0.05 \\
\hline 4.4 & 0.05 & 1.31 & 16.97 & 0.07 & 0.01 & 0.05 \\
\hline 4.6 & 0.05 & 1.31 & 17.06 & 0.07 & 0.01 & 0.05 \\
\hline 4.8 & 0.05 & 1.32 & 17.16 & 0.07 & 0.01 & 0.05 \\
\hline 5.0 & 0.05 & 1.32 & 17.18 & 0.07 & 0.01 & 0.05 \\
\hline 5.2 & 0.05 & 1.32 & 16.75 & 0.07 & 0.01 & 0.05 \\
\hline 5.4 & 0.05 & 1.31 & 15.92 & 0.07 & 0.01 & 0.05 \\
\hline 5.6 & 0.05 & 1.30 & 15.04 & 0.06 & 0.01 & 0.06 \\
\hline 5.8 & 0.05 & 1.30 & 14.15 & 0.06 & 0.01 & 0.06 \\
\hline 6.0 & 0.05 & 1.29 & 13.27 & 0.06 & 0.01 & 0.06 \\
\hline 6.2 & 0.05 & 1.28 & 12.38 & 0.06 & 0.01 & 0.06 \\
\hline 6.4 & 0.05 & 1.27 & 11.50 & 0.06 & 0.01 & 0.06 \\
\hline 6.6 & 0.05 & 1.27 & 10.62 & 0.06 & 0.01 & 0.06 \\
\hline 6.8 & 0.05 & 1.26 & 9.73 & 0.06 & 0.01 & 0.06 \\
\hline 7.0 & 0.05 & 1.25 & 8.85 & 0.06 & 0.01 & 0.06 \\
\hline 7.2 & 0.05 & 1.25 & 7.96 & 0.06 & 0.01 & 0.06 \\
\hline 7.4 & 0.05 & 1.24 & 7.08 & 0.06 & 0.00 & 0.06 \\
\hline 7.6 & 0.05 & 1.23 & 6.19 & 0.06 & 0.00 & 0.06 \\
\hline 7.8 & 0.05 & 1.22 & 5.31 & 0.06 & 0.00 & 0.06 \\
\hline 8.0 & 0.05 & 1.22 & 4.46 & 0.06 & 0.00 & 0.06 \\
\hline 8.2 & 0.05 & 1.20 & 3.83 & 0.06 & 0.00 & 0.06 \\
\hline 8.4 & 0.05 & 1.16 & 3.54 & 0.06 & 0.00 & 0.06 \\
\hline 8.6 & 0.05 & 1.13 & 3.30 & 0.06 & 0.00 & 0.05 \\
\hline 8.8 & 0.05 & 1.09 & 3.06 & 0.05 & 0.00 & 0.05 \\
\hline 9.0 & 0.05 & 1.06 & 2.83 & 0.05 & 0.00 & 0.05 \\
\hline 9.2 & 0.05 & 1.02 & 2.59 & 0.05 & 0.00 & 0.05 \\
\hline 9.4 & 0.05 & 0.99 & 2.36 & 0.05 & 0.00 & 0.05 \\
\hline 9.6 & 0.05 & 0.95 & 2.12 & 0.05 & 0.00 & 0.05 \\
\hline 9.8 & 0.05 & 0.91 & 1.89 & 0.05 & 0.00 & 0.04 \\
\hline 10.0 & 0.05 & 0.88 & 1.65 & 0.04 & 0.00 & 0.04 \\
\hline 10.2 & 0.05 & 0.84 & 1.42 & 0.04 & 0.00 & 0.04 \\
\hline 10.4 & 0.05 & 0.81 & 1.18 & 0.04 & 0.00 & 0.04 \\
\hline 10.6 & 0.05 & 0.77 & 0.95 & 0.04 & 0.00 & 0.04 \\
\hline 10.8 & 0.05 & 0.74 & 0.71 & 0.04 & 0.00 & 0.04 \\
\hline 11.0 & 0.05 & 0.70 & 0.48 & 0.04 & 0.00 & 0.03 \\
\hline 11.2 & 0.05 & 0.67 & 0.31 & 0.03 & 0.00 & 0.03 \\
\hline 11.4 & 0.05 & 0.68 & 0.29 & 0.03 & 0.00 & 0.03 \\
\hline 11.6 & 0.05 & 0.69 & 0.30 & 0.03 & 0.00 & 0.03 \\
\hline 11.8 & 0.05 & 0.70 & 0.31 & 0.04 & 0.00 & 0.03 \\
\hline 12.0 & 0.05 & 0.71 & 0.32 & 0.04 & 0.00 & 0.04 \\
\hline 12.2 & 0.05 & 0.72 & 0.33 & 0.04 & 0.00 & 0.04 \\
\hline 12.4 & 0.05 & 0.73 & 0.34 & 0.04 & 0.00 & 0.04 \\
\hline 12.6 & 0.05 & 0.74 & 0.35 & 0.04 & 0.00 & 0.04 \\
\hline 12.8 & 0.05 & 0.75 & 0.37 & 0.04 & 0.00 & 0.04 \\
\hline 13.0 & 0.05 & 0.76 & 0.38 & 0.04 & 0.00 & 0.04 \\
\hline 13.2 & 0.05 & 0.77 & 0.39 & 0.04 & 0.00 & 0.04 \\
\hline 13.4 & 0.05 & 0.78 & 0.40 & 0.04 & 0.00 & 0.04 \\
\hline 13.6 & 0.05 & 0.79 & 0.41 & 0.04 & 0.00 & 0.04 \\
\hline 13.8 & 0.05 & 0.79 & 0.42 & 0.04 & 0.00 & 0.04 \\
\hline 14.0 & 0.05 & 0.80 & 0.44 & 0.04 & 0.00 & 0.04 \\
\hline 14.2 & 0.05 & 0.81 & 0.59 & 0.04 & 0.00 & 0.04 \\
\hline
\end{tabular}


Table T14 (continued). (Continued on next page.)

\begin{tabular}{|c|c|c|c|c|c|c|}
\hline $\begin{array}{l}\text { Age } \\
\text { (Ma) }\end{array}$ & $\begin{array}{c}\text { LSR } \\
(\mathrm{cm} / \mathrm{k} \cdot \mathrm{y} .)\end{array}$ & $\begin{array}{l}\text { Dry density } \\
\left(\mathrm{g} / \mathrm{cm}^{3}\right)\end{array}$ & $\begin{array}{c}\mathrm{CaCO}_{3} \\
\text { (wt\%) }\end{array}$ & $\begin{array}{c}\text { MAR } \\
\left(\mathrm{g} / \mathrm{cm}^{2} / \mathrm{k} . \mathrm{y} .\right)\end{array}$ & $\begin{array}{c}\text { CAR } \\
\left(\mathrm{g} / \mathrm{cm}^{2} / \mathrm{k} . \mathrm{y} .\right)\end{array}$ & $\begin{array}{c}\text { nCAR } \\
\left(\mathrm{g} / \mathrm{cm}^{2} / \mathrm{k} . \mathrm{y} .\right)\end{array}$ \\
\hline 14.4 & 0.05 & 0.81 & 1.19 & 0.04 & 0.00 & 0.04 \\
\hline 14.6 & 0.05 & 0.80 & 1.95 & 0.04 & 0.00 & 0.04 \\
\hline 14.8 & 0.05 & 0.79 & 2.72 & 0.04 & 0.00 & 0.04 \\
\hline 15.0 & 0.05 & 0.78 & 3.49 & 0.04 & 0.00 & 0.04 \\
\hline 15.2 & 0.05 & 0.77 & 4.26 & 0.04 & 0.00 & 0.04 \\
\hline 15.4 & 0.05 & 0.77 & 5.03 & 0.04 & 0.00 & 0.04 \\
\hline 15.6 & 0.05 & 0.76 & 5.80 & 0.04 & 0.00 & 0.04 \\
\hline 15.8 & 0.05 & 0.75 & 6.57 & 0.04 & 0.00 & 0.04 \\
\hline 16.0 & 0.05 & 0.74 & 7.34 & 0.04 & 0.00 & 0.03 \\
\hline 16.2 & 0.05 & 0.73 & 8.11 & 0.04 & 0.00 & 0.03 \\
\hline 16.4 & 0.05 & 0.73 & 8.88 & 0.04 & 0.00 & 0.03 \\
\hline 16.6 & 0.05 & 0.72 & 9.65 & 0.04 & 0.00 & 0.03 \\
\hline 16.8 & 0.05 & 0.71 & 10.42 & 0.04 & 0.00 & 0.03 \\
\hline 17.0 & 0.05 & 0.70 & 11.18 & 0.04 & 0.00 & 0.03 \\
\hline 17.2 & 0.05 & 0.70 & 11.83 & 0.03 & 0.00 & 0.03 \\
\hline 17.4 & 0.05 & 0.69 & 11.88 & 0.03 & 0.00 & 0.03 \\
\hline 17.6 & 0.05 & 0.69 & 11.60 & 0.03 & 0.00 & 0.03 \\
\hline 17.8 & 0.05 & 0.68 & 11.29 & 0.03 & 0.00 & 0.03 \\
\hline 18.0 & 0.05 & 0.68 & 10.97 & 0.03 & 0.00 & 0.03 \\
\hline 18.2 & 0.05 & 0.68 & 10.66 & 0.03 & 0.00 & 0.03 \\
\hline 18.4 & 0.09 & 0.67 & 10.35 & 0.06 & 0.01 & 0.06 \\
\hline 18.6 & 0.09 & 0.67 & 10.04 & 0.06 & 0.01 & 0.06 \\
\hline 18.8 & 0.09 & 0.67 & 9.72 & 0.06 & 0.01 & 0.06 \\
\hline 19.0 & 0.09 & 0.66 & 9.29 & 0.06 & 0.01 & 0.06 \\
\hline 19.2 & 0.09 & 0.66 & 8.00 & 0.06 & 0.01 & 0.06 \\
\hline 19.4 & 0.09 & 0.66 & 5.85 & 0.06 & 0.00 & 0.06 \\
\hline 19.6 & 0.09 & 0.66 & 3.59 & 0.06 & 0.00 & 0.06 \\
\hline 19.8 & 0.09 & 0.66 & 1.53 & 0.06 & 0.00 & 0.06 \\
\hline 20.0 & 0.09 & 0.66 & 0.79 & 0.06 & 0.00 & 0.06 \\
\hline 20.2 & 0.09 & 0.67 & 1.06 & 0.06 & 0.00 & 0.06 \\
\hline 20.4 & 0.09 & 0.67 & 1.47 & 0.06 & 0.00 & 0.06 \\
\hline 20.6 & 0.09 & 0.68 & 1.88 & 0.06 & 0.00 & 0.06 \\
\hline 20.8 & 0.09 & 0.69 & 2.29 & 0.06 & 0.00 & 0.06 \\
\hline 21.0 & 0.09 & 0.69 & 2.70 & 0.06 & 0.00 & 0.06 \\
\hline 21.2 & 0.09 & 0.70 & 3.10 & 0.07 & 0.00 & 0.06 \\
\hline 21.4 & 0.09 & 0.71 & 3.49 & 0.07 & 0.00 & 0.06 \\
\hline 21.6 & 0.09 & 0.72 & 3.71 & 0.07 & 0.00 & 0.06 \\
\hline 21.8 & 0.09 & 0.73 & 3.74 & 0.07 & 0.00 & 0.07 \\
\hline 22.0 & 0.09 & 0.75 & 3.75 & 0.07 & 0.00 & 0.07 \\
\hline 22.2 & 0.09 & 0.76 & 3.75 & 0.07 & 0.00 & 0.07 \\
\hline 22.4 & 0.09 & 0.77 & 3.76 & 0.07 & 0.00 & 0.07 \\
\hline 22.6 & 0.09 & 0.79 & 3.76 & 0.07 & 0.00 & 0.07 \\
\hline 22.8 & 0.09 & 0.80 & 3.76 & 0.07 & 0.00 & 0.07 \\
\hline 23.0 & 0.09 & 0.82 & 3.76 & 0.08 & 0.00 & 0.07 \\
\hline 23.2 & 0.09 & 0.82 & 3.67 & 0.08 & 0.00 & 0.07 \\
\hline 23.4 & 0.09 & 0.81 & 3.45 & 0.08 & 0.00 & 0.07 \\
\hline 23.6 & 0.09 & 0.80 & 3.21 & 0.07 & 0.00 & 0.07 \\
\hline 23.8 & 0.09 & 0.79 & 2.97 & 0.07 & 0.00 & 0.07 \\
\hline 24.0 & 0.09 & 0.78 & 2.72 & 0.07 & 0.00 & 0.07 \\
\hline 24.2 & 0.09 & 0.76 & 2.48 & 0.07 & 0.00 & 0.07 \\
\hline 24.4 & 0.09 & 0.75 & 2.23 & 0.07 & 0.00 & 0.07 \\
\hline 24.6 & 0.09 & 0.74 & 2.00 & 0.07 & 0.00 & 0.07 \\
\hline 24.8 & 0.09 & 0.73 & 1.84 & 0.07 & 0.00 & 0.07 \\
\hline 25.0 & 0.09 & 0.75 & 1.86 & 0.07 & 0.00 & 0.07 \\
\hline 25.2 & 0.09 & 0.76 & 1.91 & 0.07 & 0.00 & 0.07 \\
\hline 25.4 & 0.09 & 0.77 & 1.96 & 0.07 & 0.00 & 0.07 \\
\hline 25.6 & 0.09 & 0.79 & 2.02 & 0.07 & 0.00 & 0.07 \\
\hline 25.8 & 0.09 & 0.80 & 2.03 & 0.07 & 0.00 & 0.07 \\
\hline 26.0 & 1.44 & 0.80 & 1.92 & 1.15 & 0.02 & 1.13 \\
\hline 26.2 & 1.44 & 0.75 & 2.74 & 1.08 & 0.03 & 1.05 \\
\hline 26.4 & 1.44 & 0.75 & 4.58 & 1.07 & 0.05 & 1.03 \\
\hline 26.6 & 2.19 & 0.74 & 4.56 & 1.61 & 0.07 & 1.54 \\
\hline 26.8 & 2.19 & 0.78 & 4.50 & 1.71 & 0.08 & 1.64 \\
\hline 27.0 & 2.19 & 0.83 & 4.83 & 1.82 & 0.09 & 1.73 \\
\hline 27.2 & 2.19 & 0.82 & 4.22 & 1.79 & 0.08 & 1.71 \\
\hline 27.4 & 2.19 & 0.85 & 3.33 & 1.86 & 0.06 & 1.79 \\
\hline 27.6 & 1.31 & 1.03 & 6.07 & 1.35 & 0.08 & 1.27 \\
\hline 27.8 & 1.31 & 1.08 & 6.62 & 1.42 & 0.09 & 1.32 \\
\hline 28.0 & 1.31 & 1.05 & 7.97 & 1.37 & 0.11 & 1.26 \\
\hline 28.2 & 1.31 & 1.01 & 7.26 & 1.32 & 0.10 & 1.22 \\
\hline
\end{tabular}


Table T14 (continued).

\begin{tabular}{|c|c|c|c|c|c|c|}
\hline $\begin{array}{l}\text { Age } \\
(\mathrm{Ma})\end{array}$ & $\begin{array}{c}\text { LSR } \\
(\mathrm{cm} / \mathrm{k} . \mathrm{y} .)\end{array}$ & $\begin{array}{l}\text { Dry density } \\
\left(\mathrm{g} / \mathrm{cm}^{3}\right)\end{array}$ & $\begin{array}{l}\mathrm{CaCO}_{3} \\
(\mathrm{wt} \%)\end{array}$ & $\begin{array}{c}\text { MAR } \\
\left(\mathrm{g} / \mathrm{cm}^{2} / \mathrm{k} . \mathrm{y} .\right)\end{array}$ & $\begin{array}{c}\text { CAR } \\
\left(\mathrm{g} / \mathrm{cm}^{2} / \mathrm{k} . \mathrm{y} .\right)\end{array}$ & $\begin{array}{c}\text { nCAR } \\
\left(\mathrm{g} / \mathrm{cm}^{2} / \mathrm{k} . y .\right)\end{array}$ \\
\hline 28.4 & 1.02 & 1.05 & 7.15 & 1.07 & 0.08 & 0.99 \\
\hline 28.6 & 1.02 & 1.04 & 8.74 & 1.05 & 0.09 & 0.96 \\
\hline 28.8 & 1.02 & 1.03 & 4.13 & 1.05 & 0.04 & 1.01 \\
\hline 29.0 & 1.02 & 1.09 & 2.11 & 1.11 & 0.02 & 1.09 \\
\hline 29.2 & 1.02 & 1.05 & 4.12 & 1.07 & 0.04 & 1.03 \\
\hline 29.4 & 1.02 & 1.01 & 10.79 & 1.03 & 0.11 & 0.92 \\
\hline 29.6 & 1.02 & 1.04 & 17.63 & 1.05 & 0.19 & 0.87 \\
\hline 29.8 & 1.02 & 1.07 & 16.39 & 1.09 & 0.18 & 0.91 \\
\hline 30.0 & 2.85 & 1.10 & 12.09 & 3.14 & 0.38 & 2.76 \\
\hline 30.2 & 2.85 & 1.09 & 14.67 & 3.11 & 0.46 & 2.66 \\
\hline 30.4 & 0.00 & 1.14 & 12.56 & 0.00 & 0.00 & 0.00 \\
\hline 30.6 & 0.00 & 1.13 & 13.24 & 0.00 & 0.00 & 0.00 \\
\hline 30.8 & 0.00 & 1.12 & 14.56 & 0.00 & 0.00 & 0.00 \\
\hline 31.0 & 0.83 & 1.11 & 15.24 & 0.92 & 0.14 & 0.78 \\
\hline 31.2 & 0.83 & 1.10 & 11.73 & 0.91 & 0.11 & 0.81 \\
\hline 31.4 & 0.83 & 1.13 & 6.84 & 0.93 & 0.06 & 0.87 \\
\hline 31.6 & 0.83 & 1.12 & 8.45 & 0.92 & 0.08 & 0.85 \\
\hline 31.8 & 0.83 & 1.11 & 12.95 & 0.92 & 0.12 & 0.80 \\
\hline 32.0 & 0.83 & 1.14 & 13.99 & 0.94 & 0.13 & 0.81 \\
\hline 32.2 & 0.83 & 1.16 & 15.68 & 0.96 & 0.15 & 0.81 \\
\hline 32.4 & 0.83 & 1.15 & 14.60 & 0.95 & 0.14 & 0.81 \\
\hline 32.6 & 3.76 & 1.14 & 10.86 & 4.29 & 0.47 & 3.83 \\
\hline 32.8 & 3.76 & 1.13 & 12.73 & 4.24 & 0.54 & 3.70 \\
\hline 33.0 & 3.76 & 1.10 & 18.63 & 4.14 & 0.77 & 3.37 \\
\hline 33.2 & 2.80 & 1.10 & 30.36 & 3.10 & 0.94 & 2.16 \\
\hline 33.4 & 2.80 & 1.08 & 45.09 & 3.02 & 1.36 & 1.66 \\
\hline 33.6 & 2.80 & 1.07 & 48.92 & 2.99 & 1.46 & 1.53 \\
\hline 33.8 & 5.02 & 1.23 & 34.37 & 6.16 & 2.12 & 4.04 \\
\hline 34.0 & 5.02 & 1.32 & 27.93 & 6.61 & 1.85 & 4.76 \\
\hline 34.2 & 1.29 & 1.30 & 29.95 & 1.68 & 0.50 & 1.18 \\
\hline 34.4 & 1.29 & 1.29 & 29.58 & 1.67 & 0.49 & 1.18 \\
\hline 34.6 & 1.29 & 1.31 & 28.13 & 1.69 & 0.48 & 1.22 \\
\hline 34.8 & 1.29 & 1.31 & 30.94 & 1.69 & 0.52 & 1.17 \\
\hline 35.0 & 3.04 & 1.29 & 28.51 & 3.94 & 1.12 & 2.82 \\
\hline 35.2 & 3.04 & 1.24 & 24.48 & 3.79 & 0.93 & 2.86 \\
\hline 35.4 & 3.04 & 1.22 & 25.91 & 3.70 & 0.96 & 2.74 \\
\hline 35.6 & 3.04 & 1.20 & 28.13 & 3.67 & 1.03 & 2.63 \\
\hline 35.8 & 3.04 & 1.27 & 29.44 & 3.87 & 1.14 & 2.73 \\
\hline 36.0 & 3.04 & 1.31 & 26.78 & 3.98 & 1.07 & 2.91 \\
\hline 36.2 & 2.51 & 1.25 & 25.72 & 3.14 & 0.81 & 2.33 \\
\hline 36.4 & 2.51 & 1.27 & 24.79 & 3.18 & 0.79 & 2.39 \\
\hline 36.6 & 2.51 & 1.27 & 32.97 & 3.18 & 1.05 & 2.13 \\
\hline 36.8 & 2.51 & 1.34 & 34.06 & 3.37 & 1.15 & 2.22 \\
\hline 37.0 & 2.51 & 1.34 & 35.27 & 3.36 & 1.19 & 2.18 \\
\hline 37.2 & 2.51 & 1.34 & 37.72 & 3.36 & 1.27 & 2.10 \\
\hline 37.4 & 2.51 & 1.38 & 42.88 & 3.45 & 1.48 & 1.97 \\
\hline 37.6 & 2.51 & 1.37 & 38.39 & 3.44 & 1.32 & 2.12 \\
\hline
\end{tabular}

$\mathrm{LSR}=$ linear sedimentation rate, $\mathrm{MAR}=$ mass accumulation rate, $\mathrm{CAR}=$ carbonate accumulation rate, $\mathrm{nCAR}=$ noncarbonate accumulation rate. 
Table T15. Geochemistry of headspace gas samples, Hole U1411B.

\begin{tabular}{|c|c|c|}
\hline $\begin{array}{l}\text { Core, section, } \\
\text { interval }(\mathrm{cm})\end{array}$ & $\begin{array}{l}\text { Depth } \\
\text { (mbsf) }\end{array}$ & $\begin{array}{c}\text { Methane } \\
(\mathrm{ppmv})\end{array}$ \\
\hline \multicolumn{3}{|l|}{ 342-U1411B- } \\
\hline $2 \mathrm{H}-7,0-5$ & 9.90 & 2.11 \\
\hline $3 \mathrm{H}-7,0-5$ & 19.40 & 2.41 \\
\hline $4 \mathrm{H}-7,0-5$ & 28.90 & 2.21 \\
\hline $5 \mathrm{H}-7,0-5$ & 38.40 & 2.12 \\
\hline $6 \mathrm{H}-7,0-5$ & 47.90 & 2.15 \\
\hline $7 \mathrm{H}-7,0-5$ & 57.41 & 2.16 \\
\hline $8 \mathrm{H}-7,0-5$ & 66.96 & 2.08 \\
\hline $9 \mathrm{H}-8,0-5$ & 76.15 & 2.32 \\
\hline $10 \mathrm{H}-7,0-5$ & 85.90 & 2.53 \\
\hline $11 \mathrm{H}-7,0-5$ & 95.20 & 2.59 \\
\hline $12 \mathrm{H}-7,0-5$ & 104.42 & 3.05 \\
\hline $13 \mathrm{H}-7,0-5$ & 114.44 & 2.44 \\
\hline $14 \mathrm{H}-7,0-5$ & 123.90 & 3.08 \\
\hline $15 \mathrm{H}-6,134-139$ & 132.84 & 3.44 \\
\hline $16 \mathrm{H}-5,0-5$ & 139.60 & 3.89 \\
\hline $17 \mathrm{H}-7,0-5$ & 152.00 & 3.23 \\
\hline $18 \mathrm{H}-7,0-5$ & 161.60 & 2.57 \\
\hline $19 \mathrm{H}-7,0-5$ & 171.10 & 4.12 \\
\hline $20 \mathrm{H}-4,0-5$ & 176.10 & 2.35 \\
\hline $21 X-1,0-5$ & 177.40 & 2.62 \\
\hline $23 X-6,0-5$ & 204.10 & 3.49 \\
\hline $24 X-4,0-5$ & 210.70 & 2.92 \\
\hline $25 X-5,0-5$ & 221.80 & 3.09 \\
\hline $26 X-7,0-5$ & 234.31 & 3.09 \\
\hline $27 X-6,0-5$ & 241.11 & 2.84 \\
\hline $28 X-7,0-5$ & 253.51 & 2.74 \\
\hline
\end{tabular}


Table T16. Interstitial water constituents, Hole U1411B.

\begin{tabular}{|c|c|c|c|c|c|c|c|c|c|c|c|c|c|c|c|}
\hline $\begin{array}{l}\text { Core, section, } \\
\text { interval }(\mathrm{cm})\end{array}$ & $\begin{array}{l}\text { Depth } \\
\text { (mbsf) }\end{array}$ & $\mathrm{pH}$ & $\begin{array}{c}\text { Alkalinity } \\
(\mathrm{mM})\end{array}$ & $\begin{array}{l}\mathrm{NH}_{4} \\
(\mu \mathrm{M})\end{array}$ & Salinity & $\begin{array}{c}\mathrm{Cl}^{-} \\
(\mathrm{mM})\end{array}$ & $\begin{array}{l}\mathrm{Na}^{+} \\
(\mathrm{mM})\end{array}$ & $\begin{array}{l}\mathrm{SO}_{4}{ }^{2-} \\
(\mathrm{mM})\end{array}$ & $\begin{array}{r}\mathrm{HPO}_{4}^{-} \\
(\mu \mathrm{M})\end{array}$ & $\begin{array}{l}\mathrm{Mn}^{2+} \\
(\mu \mathrm{M})\end{array}$ & $\begin{array}{c}\mathrm{Fe}^{2+} \\
(\mu \mathrm{M})\end{array}$ & $\begin{array}{l}\mathrm{Ca}^{2+} \\
(\mathrm{mM})\end{array}$ & $\begin{array}{l}\mathrm{Mg}^{2+} \\
(\mathrm{mM})\end{array}$ & $\begin{array}{c}\mathrm{K}^{+} \\
(\mathrm{mM})\end{array}$ & $\begin{array}{c}\text { B } \\
(\mu \mathrm{M})\end{array}$ \\
\hline \multicolumn{16}{|l|}{ 342-U1411B- } \\
\hline $2 \mathrm{H}-6,145-150$ & 9.85 & 7.8 & 3.20 & 11 & 37 & 541.84 & 473.71 & 27.97 & $\mathrm{BDL}$ & 14.79 & ND & 11.29 & 14.79 & 10.96 & 373.37 \\
\hline $3 \mathrm{H}-6,145-150$ & 19.35 & 7.5 & 2.99 & 8 & 37 & 547.28 & 479.44 & 27.17 & $\mathrm{BDL}$ & 7.63 & ND & 11.36 & 7.63 & 14.74 & 416.73 \\
\hline $4 \mathrm{H}-6,145-150$ & 28.85 & 7.7 & 2.98 & 11 & 38 & 548.33 & 480.00 & 27.70 & $\mathrm{BDL}$ & 5.21 & 2.03 & 11.72 & 5.21 & 12.70 & 418.16 \\
\hline $5 \mathrm{H}-6,145-150$ & 38.35 & 7.6 & 2.94 & 14 & 37 & 550.81 & 487.97 & 26.96 & $\mathrm{BDL}$ & 4.29 & 3.21 & 12.28 & 4.29 & 10.09 & 437.59 \\
\hline $6 \mathrm{H}-6,145-150$ & 47.85 & 7.8 & 2.72 & 20 & 37 & 538.78 & 472.51 & 25.66 & $\mathrm{BDL}$ & 3.16 & ND & 12.29 & 3.16 & 9.84 & 423.03 \\
\hline $7 \mathrm{H}-6,145-150$ & 57.36 & 7.5 & 2.90 & 26 & 37 & 541.63 & 477.83 & 26.70 & BDL & 3.56 & 3.00 & 12.81 & 3.56 & 8.34 & 440.12 \\
\hline $8 \mathrm{H}-6,145-150$ & 66.91 & 7.4 & 2.65 & 37 & 37 & 549.30 & 483.59 & 25.92 & BDL & 2.97 & 9.95 & 13.31 & 2.97 & 7.70 & 462.68 \\
\hline 9H-7, 96-101 & 76.10 & 7.3 & 2.94 & 39 & 37 & 540.77 & 475.98 & 24.95 & $\mathrm{BDL}$ & 3.55 & 14.19 & 13.86 & 3.55 & 8.16 & 482.21 \\
\hline $10 \mathrm{H}-6,145-150$ & 85.85 & 7.2 & 2.64 & 47 & 37 & 543.36 & 484.11 & 26.08 & BDL & 3.32 & 32.53 & 14.29 & 3.32 & 11.49 & 447.15 \\
\hline $11 \mathrm{H}-6,140-150$ & 95.10 & 7.3 & 2.82 & 55 & 37 & 550.24 & 485.88 & 25.68 & $\mathrm{BDL}$ & 3.32 & 12.37 & 14.75 & 3.32 & 11.46 & 483.37 \\
\hline $13 \mathrm{H}-6,140-150$ & 114.34 & 7.2 & 2.72 & 87 & 37 & 536.48 & 476.80 & 23.83 & $\mathrm{BDL}$ & 3.81 & 26.00 & 15.50 & 3.81 & 10.68 & 458.30 \\
\hline $19 \mathrm{H}-6,140-150$ & 171.00 & 7.2 & 2.57 & 140 & 37 & 539.21 & 478.14 & 21.69 & BDL & 4.48 & 9.56 & 18.14 & 4.48 & 8.26 & 425.40 \\
\hline $23 X-5,140-150$ & 204.00 & 7.1 & 1.86 & 185 & 37 & 545.09 & 478.27 & 20.46 & $\mathrm{BDL}$ & 3.36 & 18.72 & 19.79 & 3.36 & 7.32 & 351.13 \\
\hline $24 X-3,140-150$ & 210.60 & 7.1 & 1.96 & 198 & 37 & 541.51 & 477.54 & 21.56 & $\mathrm{BDL}$ & 4.45 & 12.51 & 19.84 & 4.45 & 7.45 & 344.95 \\
\hline $25 X-4,140-150$ & 221.70 & 7.3 & 1.50 & 212 & 37 & 556.83 & 490.65 & 21.00 & $\mathrm{BDL}$ & 2.97 & 25.44 & 20.31 & 2.97 & 7.82 & 308.45 \\
\hline $26 X-6,131-141$ & 234.21 & 7.3 & 1.33 & 239 & 37 & 554.25 & 489.42 & 20.35 & $\mathrm{BDL}$ & 2.35 & 0.86 & 20.75 & 2.35 & 7.57 & 293.76 \\
\hline $28 X-6,131-141$ & 253.41 & 6.9 & 1.50 & 241 & 37 & 545.47 & 483.41 & 20.01 & $\mathrm{BDL}$ & 2.63 & ND & 21.36 & 2.63 & 6.72 & 310.90 \\
\hline
\end{tabular}

$\mathrm{BDL}=$ below detection limit $\left(\mathrm{HPO}_{4}{ }^{-}=0.2 \mu \mathrm{M}\right)$, calculated as two times the standard deviation of multiple measures of a blank. ND = not detected. 
Table T17. Sedimentary samples and bulk elemental geochemistry, Hole U1411B. (Continued on next two pages.)

\begin{tabular}{|c|c|c|c|c|c|c|c|}
\hline \multirow{2}{*}{$\begin{array}{l}\text { Core, section, } \\
\text { interval }(\mathrm{cm})\end{array}$} & \multicolumn{2}{|c|}{ Depth (mbsf) } & \multirow{2}{*}{$\begin{array}{l}\mathrm{CaCO}_{3} \\
\text { (wt\%) }\end{array}$} & \multirow{2}{*}{$\begin{array}{c}\text { IC } \\
(w t \%)\end{array}$} & \multirow{2}{*}{$\begin{array}{c}\text { TC } \\
(w t \%)\end{array}$} & \multirow{2}{*}{$\begin{array}{c}\mathrm{TN} \\
(\mathrm{wt} \%)\end{array}$} & \multirow{2}{*}{$\begin{array}{r}\text { TOC } \\
\text { (wt } \%\end{array}$} \\
\hline & Top & Bottom & & & & & \\
\hline \multicolumn{8}{|l|}{ 342-U1411B- } \\
\hline $2 \mathrm{H}-2,38-39$ & 1.28 & 1.29 & 24.938 & 2.99 & 3.01 & 0.07 & 0.02 \\
\hline $2 \mathrm{H}-3,38-39$ & 2.78 & 2.79 & 27.248 & 3.267 & 3.55 & 0.04 & 0.28 \\
\hline $2 \mathrm{H}-4,36-37$ & 4.28 & 4.29 & 51.316 & 6.153 & 5.86 & 0.05 & $\mathrm{BDL}$ \\
\hline $2 \mathrm{H}-5,36-37$ & 5.76 & 5.77 & 31.41 & 3.766 & 3.9 & 0.06 & 0.13 \\
\hline $2 \mathrm{H}-6,31-32$ & 7.26 & 7.27 & 32.128 & 3.852 & 4.25 & 0.05 & 0.40 \\
\hline $2 \mathrm{H}-7,20-21$ & 8.71 & 8.72 & 43.331 & 5.195 & 4.76 & 0.04 & $\mathrm{BDL}$ \\
\hline $3 \mathrm{H}-1,39-40$ & 10.10 & 10.11 & 6.739 & 0.808 & 0.79 & 0.05 & $\mathrm{BDL}$ \\
\hline $3 \mathrm{H}-2,39-40$ & 10.79 & 10.8 & 15.879 & 1.904 & 1.81 & 0.04 & $\mathrm{BDL}$ \\
\hline $3 \mathrm{H}-3,39-40$ & 12.29 & 12.3 & 17.291 & 2.073 & 2.18 & 0.05 & 0.11 \\
\hline $3 \mathrm{H}-4,39-40$ & 13.79 & 13.8 & 3.852 & 0.462 & 0.67 & 0.07 & 0.21 \\
\hline $3 \mathrm{H}-5,39-40$ & 15.29 & 15.3 & 0.275 & 0.033 & 0.03 & 0.05 & 0.00 \\
\hline $3 \mathrm{H}-6,39-40$ & 16.79 & 16.8 & 0.445 & 0.053 & 0.13 & 0.07 & 0.08 \\
\hline $3 \mathrm{H}-7,16-17$ & 18.29 & 18.3 & 12.148 & 1.457 & 1.97 & 0.12 & 0.51 \\
\hline $4 \mathrm{H}-1,38-39$ & 19.56 & 19.57 & 9.253 & 1.109 & 1.12 & 0.09 & 0.01 \\
\hline $4 \mathrm{H}-2,38-39$ & 20.28 & 20.29 & 0.409 & 0.049 & 0.06 & 0.06 & 0.01 \\
\hline $4 \mathrm{H}-3,38-39$ & 21.78 & 21.79 & 3.738 & 0.448 & 0.59 & 0.1 & 0.14 \\
\hline $4 \mathrm{H}-4,38-39$ & 23.28 & 23.29 & 3.771 & 0.452 & 0.76 & 0.1 & 0.31 \\
\hline $4 \mathrm{H}-5,38-39$ & 24.78 & 24.79 & 1.793 & 0.215 & 0.6 & 0.1 & 0.39 \\
\hline $4 \mathrm{H}-6,38-39$ & 26.28 & 26.29 & 2.126 & 0.255 & 0.61 & 0.11 & 0.36 \\
\hline $4 \mathrm{H}-7,18-19$ & 27.78 & 27.79 & 0.327 & 0.039 & 0.38 & 0.12 & 0.34 \\
\hline $5 \mathrm{H}-1,38-39$ & 29.08 & 29.09 & 1.08 & 0.13 & 0.6 & 0.12 & 0.47 \\
\hline $5 \mathrm{H}-2,38-39$ & 29.78 & 29.79 & 6.381 & 0.765 & 1.12 & 0.12 & 0.35 \\
\hline $5 \mathrm{H}-3,38-39$ & 31.28 & 31.29 & 5.326 & 0.639 & 0.86 & 0.1 & 0.22 \\
\hline $5 \mathrm{H}-4,38-39$ & 32.78 & 32.79 & 4.569 & 0.548 & 0.77 & 0.09 & 0.22 \\
\hline $5 \mathrm{H}-5,38-39$ & 34.28 & 34.29 & 3.104 & 0.372 & 0.67 & 0.12 & 0.30 \\
\hline $5 \mathrm{H}-6,38-39$ & 35.78 & 35.79 & 5.556 & 0.666 & 0.83 & 0.09 & 0.16 \\
\hline $5 \mathrm{H}-7,14-15$ & 37.28 & 37.29 & 4.981 & 0.597 & 2.06 & 0.1 & 1.46 \\
\hline $6 \mathrm{H}-1,38-39$ & 38.54 & 38.55 & 2.898 & 0.347 & 0.73 & 0.12 & 0.38 \\
\hline $6 \mathrm{H}-2,38-39$ & 39.28 & 39.29 & 1.298 & 0.156 & 0.6 & 0.12 & 0.44 \\
\hline $6 \mathrm{H}-3,38-39$ & 40.78 & 40.79 & 5.093 & 0.611 & 0.9 & 0.11 & 0.29 \\
\hline $6 \mathrm{H}-4,38-39$ & 42.28 & 42.29 & 8.007 & 0.96 & 1.14 & 0.1 & 0.18 \\
\hline $6 \mathrm{H}-5,38-39$ & 43.78 & 43.79 & 4.711 & 0.565 & 0.85 & 0.11 & 0.29 \\
\hline $6 \mathrm{H}-6,38-39$ & 45.28 & 45.29 & 4.424 & 0.53 & 0.88 & 0.12 & 0.35 \\
\hline $6 \mathrm{H}-7,14-15$ & 46.78 & 46.79 & 4.995 & 0.599 & 0.9 & 0.1 & 0.30 \\
\hline 7H-1, 38-39 & 48.04 & 48.05 & 5.423 & 0.65 & 0.88 & 0.1 & 0.23 \\
\hline 7H-2, 38-39 & 48.78 & 48.79 & 4.968 & 0.596 & 0.89 & 0.1 & 0.29 \\
\hline $7 \mathrm{H}-3,38-39$ & 50.28 & 50.29 & 2.608 & 0.313 & 0.49 & 0.09 & 0.18 \\
\hline 7H-4, 38-39 & 51.78 & 51.79 & 5.953 & 0.714 & 0.84 & 0.08 & 0.13 \\
\hline 7H-5, 38-39 & 53.28 & 53.29 & 0.355 & 0.043 & 0.21 & 0.07 & 0.17 \\
\hline 7H-6, 38-39 & 54.79 & 54.8 & 2.204 & 0.264 & 0.61 & 0.11 & 0.35 \\
\hline 7H-7, 14-15 & 56.29 & 56.3 & 7.984 & 0.957 & 1.14 & 0.09 & 0.18 \\
\hline $8 \mathrm{H}-1,38-39$ & 57.55 & 57.56 & 6.552 & 0.786 & 1.19 & 0.13 & 0.40 \\
\hline $8 \mathrm{H}-2,38-39$ & 58.28 & 58.29 & 4.7 & 0.563 & 0.72 & 0.1 & 0.16 \\
\hline $8 \mathrm{H}-3,38-39$ & 59.78 & 59.79 & 7.098 & 0.851 & 1.13 & 0.11 & 0.28 \\
\hline $8 \mathrm{H}-4,38-39$ & 61.29 & 61.3 & 11.221 & 1.345 & 1.63 & 0.1 & 0.28 \\
\hline $8 \mathrm{H}-5,38-39$ & 62.82 & 62.83 & 4.892 & 0.587 & 0.9 & 0.13 & 0.31 \\
\hline $8 \mathrm{H}-6,38-39$ & 64.33 & 64.34 & 7.692 & 0.922 & 1.1 & 0.11 & 0.18 \\
\hline $8 \mathrm{H}-7,14-15$ & 65.84 & 65.85 & 7.968 & 0.955 & 1.16 & 0.11 & 0.20 \\
\hline $9 \mathrm{H}-1,10-11$ & 67.10 & 67.11 & 6.219 & 0.746 & 1 & 0.11 & 0.25 \\
\hline $9 \mathrm{H}-2,38-39$ & 67.50 & 67.51 & 4.626 & 0.555 & 0.83 & 0.12 & 0.28 \\
\hline $9 \mathrm{H}-3,38-39$ & 68.02 & 68.03 & 9.653 & 1.157 & 1.52 & 0.13 & 0.36 \\
\hline $9 \mathrm{H}-4,38-39$ & 69.52 & 69.53 & 11.195 & 1.342 & 1.51 & 0.1 & 0.17 \\
\hline $9 \mathrm{H}-5,38-39$ & 71.02 & 71.03 & 0.428 & 0.051 & 0.2 & 0.11 & 0.15 \\
\hline $9 \mathrm{H}-6,38-39$ & 72.52 & 72.53 & 1.869 & 0.224 & 0.42 & 0.11 & 0.20 \\
\hline $9 \mathrm{H}-7,20-21$ & 74.02 & 74.03 & 1.545 & 0.185 & 1.9 & 0.11 & 1.71 \\
\hline $9 \mathrm{H}-8,10-11$ & 75.34 & 75.35 & 4.663 & 0.559 & 0.96 & 0.14 & 0.40 \\
\hline $10 \mathrm{H}-1,38-39$ & 76.25 & 76.26 & 10.289 & 1.234 & 1.5 & 0.12 & 0.27 \\
\hline $10 \mathrm{H}-2,38-39$ & 77.28 & 77.29 & 10.923 & 1.31 & 1.45 & 0.1 & 0.14 \\
\hline $10 \mathrm{H}-3,38-39$ & 78.78 & 78.79 & 21.03 & 2.521 & 2.74 & 0.1 & 0.22 \\
\hline $10 \mathrm{H}-4,38-39$ & 80.28 & 80.29 & 17.769 & 2.13 & 2.4 & 0.12 & 0.27 \\
\hline $10 \mathrm{H}-5,38-39$ & 81.78 & 81.79 & 15.63 & 1.874 & 2.2 & 0.13 & 0.33 \\
\hline $10 \mathrm{H}-6,38-39$ & 83.28 & 83.29 & 4.482 & 0.537 & 0.19 & 0.13 & BDL \\
\hline $10 \mathrm{H}-7,16-17$ & 84.78 & 84.79 & 14.425 & 1.729 & 2.04 & 0.11 & 0.31 \\
\hline $11 \mathrm{H}-1,32-33$ & 86.06 & 86.07 & 13.076 & 1.568 & 1.82 & 0.12 & 0.25 \\
\hline $11 \mathrm{H}-1,32-33$ & 86.72 & 86.73 & 25.335 & 3.038 & 3.37 & 0.1 & 0.33 \\
\hline $11 \mathrm{H}-2,38-39$ & 86.72 & 86.73 & 26.143 & 3.134 & & & \\
\hline
\end{tabular}


Table T17 (continued). (Continued on next page.)

\begin{tabular}{|c|c|c|c|c|c|c|c|}
\hline \multirow{2}{*}{$\begin{array}{l}\text { Core, section, } \\
\text { interval }(\mathrm{cm})\end{array}$} & \multicolumn{2}{|c|}{ Depth (mbsf) } & \multirow{2}{*}{$\begin{array}{l}\mathrm{CaCO}_{3} \\
(\mathrm{wt} \%)\end{array}$} & \multirow{2}{*}{$\begin{array}{c}\text { IC } \\
\text { (wt\%) }\end{array}$} & \multirow{2}{*}{$\begin{array}{c}\text { TC } \\
\text { (wt\%) }\end{array}$} & \multirow{2}{*}{$\begin{array}{c}\mathrm{TN} \\
\text { (wt\%) }\end{array}$} & \multirow{2}{*}{$\begin{array}{c}\text { TOC } \\
\text { (wt\%) }\end{array}$} \\
\hline & Top & Bottom & & & & & \\
\hline $11 \mathrm{H}-3,38-39$ & 88.28 & 88.29 & 16.923 & 2.029 & 2.49 & 0.14 & 0.46 \\
\hline $11 \mathrm{H}-4,38-39$ & 89.78 & 89.79 & 12.398 & 1.487 & 1.96 & 0.13 & 0.47 \\
\hline $11 \mathrm{H}-5,38-39$ & 91.08 & 91.09 & 11.047 & 1.325 & 1.52 & 0.08 & 0.20 \\
\hline $11 \mathrm{H}-6,38-39$ & 92.58 & 92.59 & 16.817 & 2.016 & 2.63 & 0.15 & 0.61 \\
\hline $11 \mathrm{H}-7,14-15$ & 94.08 & 94.09 & 3.435 & 0.412 & 0.8 & 0.12 & 0.39 \\
\hline $12 \mathrm{H}-1,37-38$ & 95.34 & 95.35 & 7.793 & 0.934 & 1.25 & 0.11 & 0.32 \\
\hline $12 \mathrm{H}-2,38-39$ & 96.27 & 96.28 & 6.476 & 0.776 & 1.6 & 0.15 & 0.82 \\
\hline $12 \mathrm{H}-3,38-39$ & 97.78 & 97.79 & 14.395 & 1.726 & 2.14 & 0.13 & 0.41 \\
\hline $12 \mathrm{H}-4,38-39$ & 99.28 & 99.29 & 13.485 & 1.617 & 2.17 & 0.13 & 0.55 \\
\hline $12 \mathrm{H}-5,22-23$ & 100.78 & 100.79 & 14.073 & 1.687 & 2 & 0.13 & 0.31 \\
\hline $12 \mathrm{H}-6,42-43$ & 102.12 & 102.13 & 18.602 & 2.23 & 2.66 & 0.11 & 0.43 \\
\hline $12 \mathrm{H}-7,14-15$ & 103.34 & 103.35 & 15.161 & 1.818 & 2.19 & 0.12 & 0.37 \\
\hline $13 \mathrm{H}-1,38-39$ & 104.56 & 104.57 & 6.183 & 0.741 & 1.34 & 0.13 & 0.60 \\
\hline $13 \mathrm{H}-2,38-39$ & 105.78 & 105.79 & 8.888 & 1.066 & 1.42 & 0.13 & 0.35 \\
\hline $13 \mathrm{H}-3,38-39$ & 107.28 & 107.29 & 14.615 & 1.752 & 2.23 & 0.13 & 0.48 \\
\hline $13 \mathrm{H}-4,38-39$ & 108.78 & 108.79 & 7.654 & 0.918 & 1.37 & 0.14 & 0.45 \\
\hline $13 \mathrm{H}-5,38-39$ & 110.29 & 110.3 & 10.67 & 1.279 & 1.65 & 0.12 & 0.37 \\
\hline $13 \mathrm{H}-6,38-39$ & 111.80 & 111.81 & 9.565 & 1.147 & 1.62 & 0.14 & 0.47 \\
\hline $13 \mathrm{H}-7,16-17$ & 113.32 & 113.33 & 7.244 & 0.869 & 1.43 & 0.14 & 0.56 \\
\hline $14 \mathrm{H}-1,38-39$ & 114.60 & 114.61 & 14.107 & 1.691 & 2.08 & 0.12 & 0.39 \\
\hline $14 \mathrm{H}-2,38-39$ & 115.28 & 115.29 & 7.318 & 0.877 & 1.27 & 0.11 & 0.39 \\
\hline $14 \mathrm{H}-3,38-39$ & 116.78 & 116.79 & 16.4 & 1.966 & 2.31 & 0.12 & 0.34 \\
\hline $14 \mathrm{H}-4,38-39$ & 118.28 & 118.29 & 19.403 & 2.326 & 2.64 & 0.11 & 0.31 \\
\hline $14 \mathrm{H}-5,38-39$ & 119.78 & 119.79 & 13.546 & 1.624 & 2.02 & 0.13 & 0.40 \\
\hline $14 \mathrm{H}-6,38-39$ & 121.28 & 121.29 & 12.313 & 1.476 & 1.92 & 0.12 & 0.44 \\
\hline $14 \mathrm{H}-7,14-15$ & 122.78 & 122.79 & 15.076 & 1.808 & 2.3 & 0.15 & 0.49 \\
\hline $15 \mathrm{H}-1,38-39$ & 124.04 & 124.05 & 17.731 & 2.126 & 2.59 & 0.12 & 0.46 \\
\hline $15 \mathrm{H}-2,38-39$ & 124.78 & 124.79 & 22.817 & 2.736 & 3.23 & 0.11 & 0.49 \\
\hline $15 \mathrm{H}-3,38-39$ & 126.20 & 126.21 & 36.523 & 4.379 & 4.52 & 0.08 & 0.14 \\
\hline $15 \mathrm{H}-4,34-35$ & 127.68 & 127.69 & 23.762 & 2.849 & 3.26 & 0.11 & 0.41 \\
\hline $15 \mathrm{H}-5,31-32$ & 129.10 & 129.11 & 22.853 & 2.74 & 3.01 & 0.1 & 0.27 \\
\hline $15 \mathrm{H}-6,33-34$ & 130.52 & 130.53 & 34.732 & 4.164 & 4.39 & 0.09 & 0.23 \\
\hline $16 \mathrm{H}-1,38-39$ & 131.83 & 131.84 & 33.003 & 3.957 & 4.3 & 0.1 & 0.34 \\
\hline $16 \mathrm{H}-2,38-39$ & 133.98 & 133.99 & 39.443 & 4.729 & 5.07 & 0.1 & 0.34 \\
\hline $16 \mathrm{H}-2,38-39$ & 135.48 & 135.49 & 54.816 & 6.572 & 6.71 & 0.06 & 0.14 \\
\hline $16 \mathrm{H}-3,38-39$ & 135.48 & 135.49 & 55.264 & 6.626 & & & \\
\hline $16 \mathrm{H}-4,38-39$ & 136.98 & 136.99 & 45.731 & 5.483 & 5.72 & 0.08 & 0.24 \\
\hline $16 \mathrm{H}-5,38-39$ & 138.48 & 138.49 & 51.858 & 6.218 & 6.34 & 0.07 & 0.12 \\
\hline $17 \mathrm{H}-1,40-41$ & 139.98 & 139.99 & 53.01 & 6.356 & 6.58 & 0.06 & 0.22 \\
\hline $17 \mathrm{H}-2,40-41$ & 143.50 & 143.51 & 52.128 & 6.25 & 6.19 & 0.05 & $\mathrm{BDL}$ \\
\hline $17 \mathrm{H}-3,40-41$ & 145.00 & 145.01 & 33.961 & 4.072 & 12.54 & 0.11 & 8.47 \\
\hline $17 \mathrm{H}-4,40-41$ & 146.50 & 146.51 & 39.025 & 4.679 & 7.59 & 0.09 & 2.91 \\
\hline $17 \mathrm{H}-4,40-41$ & 148.00 & 148.01 & 17.002 & 2.038 & 4.43 & 0.11 & 2.39 \\
\hline $17 \mathrm{H}-5,38-39$ & 148.00 & 148.01 & 17.538 & 2.103 & & & \\
\hline $17 \mathrm{H}-6,13-14$ & 149.48 & 149.49 & 33.121 & 3.971 & 11.53 & 0.1 & 7.56 \\
\hline $17 \mathrm{H}-7,28-29$ & 150.73 & 150.74 & 32.419 & 3.887 & 9.27 & 0.095 & 5.38 \\
\hline $18 \mathrm{H}-1,38-39$ & 152.28 & 152.29 & 37.936 & 4.548 & 12.7 & 0.09 & 8.15 \\
\hline $18 \mathrm{H}-2,38-39$ & 152.98 & 152.99 & 35.452 & 4.251 & 4.25 & 0.07 & $\mathrm{BDL}$ \\
\hline $18 \mathrm{H}-3,38-39$ & 154.48 & 154.49 & 29.728 & 3.564 & 10.96 & 0.1 & 7.40 \\
\hline $18 \mathrm{H}-4,38-39$ & 155.98 & 155.99 & 29.839 & 3.578 & 10.87 & 3.09 & 7.29 \\
\hline $18 \mathrm{H}-5,38-39$ & 157.48 & 157.49 & 30.201 & 3.621 & 10.78 & 0.095 & 7.16 \\
\hline $18 \mathrm{H}-6,38-39$ & 158.98 & 158.99 & 29.503 & 3.537 & 10.86 & 0.1 & 7.32 \\
\hline $18 \mathrm{H}-7,30-31$ & 160.48 & 160.49 & 28.098 & 3.369 & 10.09 & 0.03 & 6.72 \\
\hline $19 \mathrm{H}-1,38-39$ & 161.90 & 161.91 & 18.477 & 2.215 & 7.03 & 0.125 & 4.81 \\
\hline $19 \mathrm{H}-2,38-39$ & 162.48 & 162.49 & 32.443 & 3.89 & 11.84 & 0.11 & 7.95 \\
\hline $19 \mathrm{H}-3,38-39$ & 163.98 & 163.99 & 40.646 & 4.873 & 4.89 & 0.08 & 0.02 \\
\hline $19 \mathrm{H}-4,38-39$ & 165.48 & 165.49 & 24.796 & 2.973 & 8.84 & 0.1 & 5.87 \\
\hline $19 \mathrm{H}-5,38-39$ & 166.98 & 166.99 & 26.673 & 3.198 & 9.9 & 0.11 & 6.70 \\
\hline $19 \mathrm{H}-6,10-11$ & 168.48 & 168.49 & 26.446 & 3.171 & 9.48 & 0.11 & 6.31 \\
\hline $19 \mathrm{H}-7,27-28$ & 169.70 & 169.71 & 37.767 & 4.528 & 4.74 & 0.08 & 0.21 \\
\hline $20 \mathrm{H}-1,38-39$ & 171.37 & 171.38 & 25.514 & 3.059 & 3.13 & 0.09 & 0.07 \\
\hline $20 \mathrm{H}-2,38-39$ & 171.98 & 171.99 & 33.923 & 4.067 & 4.05 & 0.08 & $\mathrm{BDL}$ \\
\hline $20 \mathrm{H}-3,38-39$ & 173.48 & 173.49 & 26.57 & 3.186 & 3.36 & 0.08 & 0.17 \\
\hline $20 \mathrm{H}-4,38-39$ & 174.98 & 174.99 & 27.594 & 3.308 & 3.39 & 0.09 & 0.08 \\
\hline $21 \mathrm{X}-1,10-11$ & 176.48 & 176.49 & 21.21 & 2.543 & 7.91 & 0.109 & 5.37 \\
\hline $23 \mathrm{X}-1,38-39$ & 177.50 & 177.51 & 23.161 & 2.777 & 2.87 & 0.09 & 0.09 \\
\hline $23 \mathrm{X}-2,38-39$ & 196.98 & 196.99 & 30.261 & 3.628 & 11.12 & 0.12 & 7.49 \\
\hline $23 X-3,38-39$ & 198.48 & 198.49 & 36.036 & 4.321 & 12.80 & 0.099 & 8.48 \\
\hline $23 X-4,38-39$ & 199.98 & 199.99 & 22.686 & 2.72 & 8.47 & 0.13 & 5.75 \\
\hline $23 X-5,38-39$ & 201.48 & 201.49 & 25.334 & 3.037 & 8.64 & 0.03 & 5.60 \\
\hline
\end{tabular}


Table T17 (continued).

\begin{tabular}{|c|c|c|c|c|c|c|c|}
\hline \multirow{2}{*}{$\begin{array}{l}\text { Core, section, } \\
\text { interval }(\mathrm{cm})\end{array}$} & \multicolumn{2}{|c|}{ Depth (mbsf) } & \multirow{2}{*}{$\begin{array}{c}\mathrm{CaCO}_{3} \\
\text { (wt\%) }\end{array}$} & \multirow{2}{*}{$\begin{array}{c}\mathrm{IC} \\
(w \mathrm{t} \%)\end{array}$} & \multirow{2}{*}{$\begin{array}{c}\mathrm{TC} \\
(\mathrm{wt} \%)\end{array}$} & \multirow{2}{*}{$\begin{array}{c}\mathrm{TN} \\
(\mathrm{wt} \%)\end{array}$} & \multirow{2}{*}{$\begin{array}{l}\text { TOC } \\
\text { (wt\%) }\end{array}$} \\
\hline & Top & Bottom & & & & & \\
\hline $23 X-6,25-26$ & 202.98 & 202.99 & 21.785 & 2.612 & 8.12 & 0.115 & 5.51 \\
\hline $24 X-1,38-39$ & 204.35 & 204.36 & 32.218 & 3.863 & 3.87 & 0.08 & 0.01 \\
\hline $24 X-2,38-39$ & 206.58 & 206.59 & 25.991 & 3.116 & 9.57 & 0.12 & 6.45 \\
\hline $24 X-3,38-39$ & 208.08 & 208.09 & 27.954 & 3.352 & & 0.12 & \\
\hline $24 X-4,38-39$ & 209.58 & 209.59 & 24.009 & 2.879 & 9.03 & 0.13 & 6.15 \\
\hline $25 X-1,43-44$ & 211.08 & 211.09 & 26.728 & 3.205 & 10.28 & 0.13 & 7.08 \\
\hline $25 X-2,38-39$ & 216.23 & 216.24 & 20.139 & 2.415 & 7.75 & 0.13 & 5.34 \\
\hline $25 X-3,38-39$ & 217.68 & 217.69 & 31.68 & 3.798 & 11.7 & 0.12 & 7.90 \\
\hline $25 X-3,38-39$ & 219.18 & 219.19 & 44.824 & 5.374 & 15.89 & 0.09 & 10.52 \\
\hline $25 X-4,38-39$ & 219.18 & 219.19 & 44.452 & 5.33 & & & \\
\hline $25 X-5,12-13$ & 220.68 & 220.69 & 29.723 & 3.564 & 10.37 & 0.1 & 6.81 \\
\hline $26 X-1,38-39$ & 221.92 & 221.93 & 30.908 & 3.706 & 10.89 & 0.1 & 7.18 \\
\hline $26 X-2,38-39$ & 225.78 & 225.79 & 36.515 & 4.378 & 12.92 & 0.09 & 8.54 \\
\hline $26 X-3,38-39$ & 227.28 & 227.29 & 30.563 & 3.664 & 10.98 & 0.1 & 7.32 \\
\hline $26 X-4,38-39$ & 228.78 & 228.79 & 39.015 & 4.678 & 13.8 & 0.1 & 9.12 \\
\hline $26 X-5,38-39$ & 230.28 & 230.29 & 34.215 & 4.102 & 12.5 & 0.1 & 8.40 \\
\hline $26 X-6,38-39$ & 231.78 & 231.79 & 35.665 & 4.276 & 12.58 & 0.09 & 8.30 \\
\hline $26 X-7,11-12$ & 233.28 & 233.29 & 31.814 & 3.814 & 11.61 & 0.1 & 7.80 \\
\hline $27 X-1,21-22$ & 234.42 & 234.43 & 41.908 & 5.025 & 14.83 & 0.08 & 9.81 \\
\hline $27 X-2,10-11$ & 235.21 & 235.22 & 34.577 & 4.146 & 7.39 & 0.09 & 3.24 \\
\hline $27 X-3,10-11$ & 236.13 & 236.14 & 43.722 & 5.242 & 15.44 & 0.08 & 10.20 \\
\hline $27 X-4,35-36$ & 236.81 & 236.82 & 36.142 & 4.333 & 9.6 & 0.08 & 5.27 \\
\hline $27 X-5,21-22$ & 238.47 & 238.48 & 51.751 & 6.205 & 18.34 & 0.06 & 12.14 \\
\hline $27 X-6,11-12$ & 239.82 & 239.83 & 47.017 & 5.637 & 16.53 & 0.08 & 10.89 \\
\hline $27 X-7,19-20$ & 241.22 & 241.23 & 37.423 & 4.487 & 13.12 & 0.07 & 8.63 \\
\hline $28 X-1,38-39$ & 241.81 & 241.82 & 42.169 & 5.056 & 14.73 & 0.07 & 9.67 \\
\hline $28 X-2,38-39$ & 244.98 & 244.99 & 38.151 & 4.574 & 13.47 & 0.08 & 8.90 \\
\hline $28 X-3,43-44$ & 246.48 & 246.49 & 34.788 & 4.171 & 12.2 & 0.09 & 8.03 \\
\hline $28 X-4,38-39$ & 248.03 & 248.04 & 32.833 & 3.937 & 11.77 & 0.1 & 7.83 \\
\hline $28 X-5,40-41$ & 249.48 & 249.49 & 39.833 & 4.776 & 13.81 & 0.07 & 9.03 \\
\hline $28 X-6,22-23$ & 251.00 & 251.01 & 41.759 & 5.007 & 15.09 & 0.08 & 10.08 \\
\hline $28 X-6,22-23$ & 252.32 & 252.33 & 27.911 & 3.346 & 5.8 & 0.09 & 2.45 \\
\hline \multirow[t]{2}{*}{ 28X-7, 9-10 } & 252.32 & 252.33 & 27.487 & 3.296 & & & \\
\hline & 253.60 & 253.61 & 39.895 & 4.783 & 14.22 & 0.07 & 9.44 \\
\hline
\end{tabular}

$\mathrm{IC}=$ inorganic carbon, $\mathrm{TC}=$ total carbon, $\mathrm{TN}=$ total nitrogen, $\mathrm{TOC}=$ total organic carbon. $\mathrm{BDL}=$ below detection limit $(\mathrm{TOC}<0.03 \mathrm{wt} \%)$. 
Table T18. Thermal conductivity results, Hole U1411B. (Continued on next page.)

\begin{tabular}{|c|c|c|c|c|c|}
\hline \multirow[b]{2}{*}{$\begin{array}{l}\text { Core, section, } \\
\text { interval }(\mathrm{cm})\end{array}$} & \multirow[b]{2}{*}{$\begin{array}{l}\text { Depth } \\
\text { (mbsf) }\end{array}$} & \multicolumn{3}{|c|}{ Thermal conductivity $(\mathrm{W} /[\mathrm{m} \cdot \mathrm{K}])$} & \multirow{2}{*}{$\begin{array}{l}\text { Heating } \\
\text { power } \\
(\mathrm{W} / \mathrm{m})\end{array}$} \\
\hline & & Mean & $\begin{array}{l}\text { Standard } \\
\text { deviation }\end{array}$ & Observation & \\
\hline \multicolumn{6}{|l|}{ 342-U1411B- } \\
\hline $2 \mathrm{H}-3 \mathrm{~W}, 75$ & 3.91 & 1.552 & $3.42 \mathrm{E}-02$ & $1.514^{*}$ & 1.613 \\
\hline $2 \mathrm{H}-3 \mathrm{~W}, 75$ & 3.91 & & & $1.597^{*}$ & 1.612 \\
\hline $2 \mathrm{H}-3 \mathrm{~W}, 75$ & 3.91 & & & $1.545^{*}$ & 1.612 \\
\hline $3 \mathrm{H}-3 \mathrm{~W}, 75$ & 13.41 & 1.781 & $4.14 \mathrm{E}-02$ & 1.733 & 1.612 \\
\hline $3 \mathrm{H}-3 \mathrm{~W}, 75$ & 13.41 & & & $1.834^{*}$ & 1.612 \\
\hline $3 \mathrm{H}-3 \mathrm{~W}, 75$ & 13.41 & & & $1.775^{*}$ & 1.612 \\
\hline $4 \mathrm{H}-3 \mathrm{~W}, 75$ & 22.91 & 1.08 & $3.68 \mathrm{E}-02$ & $1.029^{*}$ & 1.612 \\
\hline $4 \mathrm{H}-3 \mathrm{~W}, 75$ & 22.91 & & & 1.099 & 1.612 \\
\hline $4 \mathrm{H}-3 \mathrm{~W}, 75$ & 22.91 & & & 1.113 & 1.612 \\
\hline $5 \mathrm{H}-3 \mathrm{~W}, 75$ & 32.41 & 1.069 & $1.13 \mathrm{E}-02$ & 1.054 & 1.612 \\
\hline $5 \mathrm{H}-3 \mathrm{~W}, 75$ & 32.41 & & & $1.08^{*}$ & 1.612 \\
\hline $5 \mathrm{H}-3 \mathrm{~W}, 75$ & 32.41 & & & $1.074^{*}$ & 1.612 \\
\hline $6 \mathrm{H}-3 \mathrm{~A}, 75$ & 41.91 & 1.095 & $6.70 \mathrm{E}-03$ & 1.089 & 1.612 \\
\hline $6 \mathrm{H}-3 \mathrm{~A}, 75$ & 41.91 & & & 1.092 & 1.612 \\
\hline $6 \mathrm{H}-3 \mathrm{~A}, 75$ & 41.91 & & & 1.104 & 1.612 \\
\hline $7 \mathrm{H}-3 \mathrm{~A}, 75$ & 51.41 & 1.176 & $3.09 \mathrm{E}-02$ & $1.133^{*}$ & 1.612 \\
\hline $7 \mathrm{H}-3 \mathrm{~A}, 75$ & 51.41 & & & $1.203^{*}$ & 1.612 \\
\hline $7 \mathrm{H}-3 \mathrm{~A}, 75$ & 51.41 & & & $1.193^{*}$ & 1.612 \\
\hline $8 \mathrm{H}-3 \mathrm{~A}, 75$ & 60.92 & 1.294 & $2.72 \mathrm{E}-02$ & 1.272 & 1.612 \\
\hline $8 \mathrm{H}-3 \mathrm{~A}, 75$ & 60.92 & & & $1.332^{*}$ & 1.612 \\
\hline $8 \mathrm{H}-3 \mathrm{~A}, 75$ & 60.92 & & & $1.277^{*}$ & 1.612 \\
\hline $9 \mathrm{H}-3 \mathrm{~A}, 75$ & 69.15 & 1.259 & $1.56 \mathrm{E}-02$ & $1.239^{*}$ & 1.612 \\
\hline $9 \mathrm{H}-3 \mathrm{~A}, 75$ & 69.15 & & & $1.277^{*}$ & 1.612 \\
\hline $9 \mathrm{H}-3 \mathrm{~A}, 75$ & 69.15 & & & $1.262^{*}$ & 1.612 \\
\hline $10 \mathrm{H}-3 \mathrm{~A}, 75$ & 79.91 & 1.152 & $5.09 \mathrm{E}-02$ & $1.164^{*}$ & 1.612 \\
\hline $10 \mathrm{H}-3 \mathrm{~A}, 75$ & 79.91 & & & $1.085^{*}$ & 1.612 \\
\hline $10 \mathrm{H}-3 \mathrm{~A}, 75$ & 79.91 & & & $1.208^{*}$ & 1.612 \\
\hline $11 \mathrm{H}-3 \mathrm{~A}, 75$ & 89.41 & 1.228 & $1.74 \mathrm{E}-02$ & $1.208^{*}$ & 1.612 \\
\hline $11 \mathrm{H}-3 \mathrm{~A}, 75$ & 89.41 & & & $1.226^{*}$ & 1.612 \\
\hline $11 \mathrm{H}-3 \mathrm{~A}, 75$ & 89.41 & & & 1.250 & 1.612 \\
\hline $12 \mathrm{H}-3 \mathrm{~A}, 75$ & 98.91 & 1.246 & $3.44 \mathrm{E}-02$ & 1.202 & 1.612 \\
\hline $12 \mathrm{H}-3 \mathrm{~A}, 75$ & 98.91 & & & 1.285 & 1.612 \\
\hline $12 \mathrm{H}-3 \mathrm{~A}, 75$ & 98.91 & & & $1.25^{*}$ & 1.612 \\
\hline $13 \mathrm{H}-3 \mathrm{~A}, 75$ & 108.41 & 1.141 & $6.70 \mathrm{E}-03$ & 1.132 & 1.612 \\
\hline $13 \mathrm{H}-3 \mathrm{~A}, 75$ & 108.41 & & & $1.149^{*}$ & 1.612 \\
\hline $13 \mathrm{H}-3 \mathrm{~A}, 75$ & 108.41 & & & 1.141 & 1.612 \\
\hline $14 \mathrm{H}-3 \mathrm{~W}, 75$ & 117.91 & 1.198 & $3.86 \mathrm{E}-02$ & $1.147^{*}$ & 1.612 \\
\hline $14 \mathrm{H}-3 \mathrm{~W}, 75$ & 117.91 & & & $1.208^{*}$ & 1.612 \\
\hline $14 \mathrm{H}-3 \mathrm{~W}, 75$ & 117.91 & & & 1.240 & 1.612 \\
\hline $15 \mathrm{H}-3 \mathrm{~W}, 75$ & 127.31 & 1.171 & $4.80 \mathrm{E}-02$ & 1.106 & 1.612 \\
\hline $15 \mathrm{H}-3 \mathrm{~W}, 75$ & 127.31 & & & $1.185^{*}$ & 1.612 \\
\hline $15 \mathrm{H}-3 \mathrm{~W}, 75$ & 127.31 & & & 1.222 & 1.612 \\
\hline $16 \mathrm{H}-3 \mathrm{~W}, 75$ & 136.61 & 1.097 & $1.63 \mathrm{E}-01$ & 0.867 & 1.612 \\
\hline $16 \mathrm{H}-3 \mathrm{~W}, 75$ & 136.61 & & & $1.229^{*}$ & 1.612 \\
\hline $16 \mathrm{H}-3 \mathrm{~W}, 75$ & 136.61 & & & $1.194^{*}$ & 1.612 \\
\hline $17 \mathrm{H}-3 \mathrm{~W}, 75$ & 146.11 & 1.148 & $3.82 \mathrm{E}-02$ & $1.094^{*}$ & 1.612 \\
\hline $17 \mathrm{H}-3 \mathrm{~W}, 75$ & 146.11 & & & $1.176^{*}$ & 1.612 \\
\hline $17 \mathrm{H}-3 \mathrm{~W}, 75$ & 146.11 & & & $1.174^{*}$ & 1.612 \\
\hline $18 \mathrm{H}-3 \mathrm{~W}, 75$ & 155.61 & 1.331 & $1.00 \mathrm{E}-02$ & $1.317^{*}$ & 1.612 \\
\hline $18 \mathrm{H}-3 \mathrm{~W}, 75$ & 155.61 & & & $1.340^{*}$ & 1.612 \\
\hline $18 \mathrm{H}-3 \mathrm{~W}, 75$ & 155.61 & & & $1.336^{*}$ & 1.612 \\
\hline $19 \mathrm{H}-3 \mathrm{~W}, 75$ & 165.11 & 1.148 & $1.14 \mathrm{E}-02$ & 1.133 & 1.612 \\
\hline $19 \mathrm{H}-3 \mathrm{~W}, 75$ & 165.11 & & & 1.161 & 1.612 \\
\hline $19 \mathrm{H}-3 \mathrm{~W}, 75$ & 165.11 & & & 1.149 & 1.612 \\
\hline $20 \mathrm{H}-3 \mathrm{~A}, 75$ & 174.61 & 1.324 & $2.14 \mathrm{E}-02$ & $1.353^{*}$ & 1.612 \\
\hline $20 \mathrm{H}-3 \mathrm{~A}, 75$ & 174.61 & & & $1.317^{*}$ & 1.612 \\
\hline $20 \mathrm{H}-3 \mathrm{~A}, 75$ & 174.61 & & & $1.302^{*}$ & 1.612 \\
\hline $23 \mathrm{X}-3 \mathrm{~A}, 75$ & 199.61 & 1.284 & $1.56 \mathrm{E}-02$ & $1.262^{*}$ & 1.612 \\
\hline $23 \mathrm{X}-3 \mathrm{~A}, 75$ & 199.61 & & & $1.294^{*}$ & 1.612 \\
\hline $23 \mathrm{X}-3 \mathrm{~A}, 75$ & 199.61 & & & $1.296^{*}$ & 1.612 \\
\hline $24 X-3 A, 75$ & 209.21 & 1.237 & $9.40 \mathrm{E}-03$ & $1.237^{*}$ & 1.612 \\
\hline $24 \mathrm{X}-3 \mathrm{~A}, 75$ & 209.21 & & & $1.249^{*}$ & 1.612 \\
\hline $24 \mathrm{X}-3 \mathrm{~A}, 75$ & 209.21 & & & $1.226^{*}$ & 1.612 \\
\hline $25 X-3 A, 75$ & 218.81 & 1.262 & $3.40 \mathrm{E}-03$ & $1.257^{*}$ & 1.612 \\
\hline $25 \mathrm{X}-3 \mathrm{~A}, 75$ & 218.81 & & & $1.263^{*}$ & 1.612 \\
\hline $25 X-3 A, 75$ & 218.81 & & & $1.265^{*}$ & 1.612 \\
\hline
\end{tabular}


Table T18 (continued).

\begin{tabular}{|c|c|c|c|c|c|}
\hline \multirow[b]{2}{*}{$\begin{array}{l}\text { Core, section, } \\
\text { interval }(\mathrm{cm})\end{array}$} & \multirow[b]{2}{*}{$\begin{array}{l}\text { Depth } \\
\text { (mbsf) }\end{array}$} & \multicolumn{3}{|c|}{ Thermal conductivity $(\mathrm{W} /[\mathrm{m} \cdot \mathrm{K}])$} & \multirow{2}{*}{$\begin{array}{l}\text { Heating } \\
\text { power } \\
(\mathrm{W} / \mathrm{m})\end{array}$} \\
\hline & & Mean & $\begin{array}{l}\text { Standard } \\
\text { deviation }\end{array}$ & Observation & \\
\hline $26 X-3 A, 68$ & 228.41 & 1.281 & $1.02 \mathrm{E}-02$ & $1.269^{\star}$ & 1.612 \\
\hline $26 X-3 A, 68$ & 228.41 & & & $1.294^{*}$ & 1.612 \\
\hline $26 X-3 A, 68$ & 228.41 & & & $1.281^{*}$ & 1.612 \\
\hline $27 X-3 A, 70$ & 236.72 & 1.304 & $7.70 \mathrm{E}-03$ & 1.298 & 1.612 \\
\hline $27 X-3 A, 68$ & 236.72 & & & 1.315 & 1.612 \\
\hline $27 X-3 A, 68$ & 236.72 & & & 1.299 & 1.612 \\
\hline $28 X-3 A, 68$ & 247.61 & 1.352 & $4.50 \mathrm{E}-03$ & $1.349^{*}$ & 1.612 \\
\hline $28 X-3 A, 68$ & 247.61 & & & $1.358^{*}$ & 1.612 \\
\hline $28 X-3 A, 68$ & 247.61 & & & $1.348^{*}$ & 1.612 \\
\hline
\end{tabular}

* $=$ result obtained directly from the TK04 processing software. Other results were generated by the IODP uploader using raw data because they were rejected by the TK04 software. Thermal conductivity mean and standard deviation calculated from thermal conductivity observations. 
Table T19. Core top and composite depths, Site U1411.

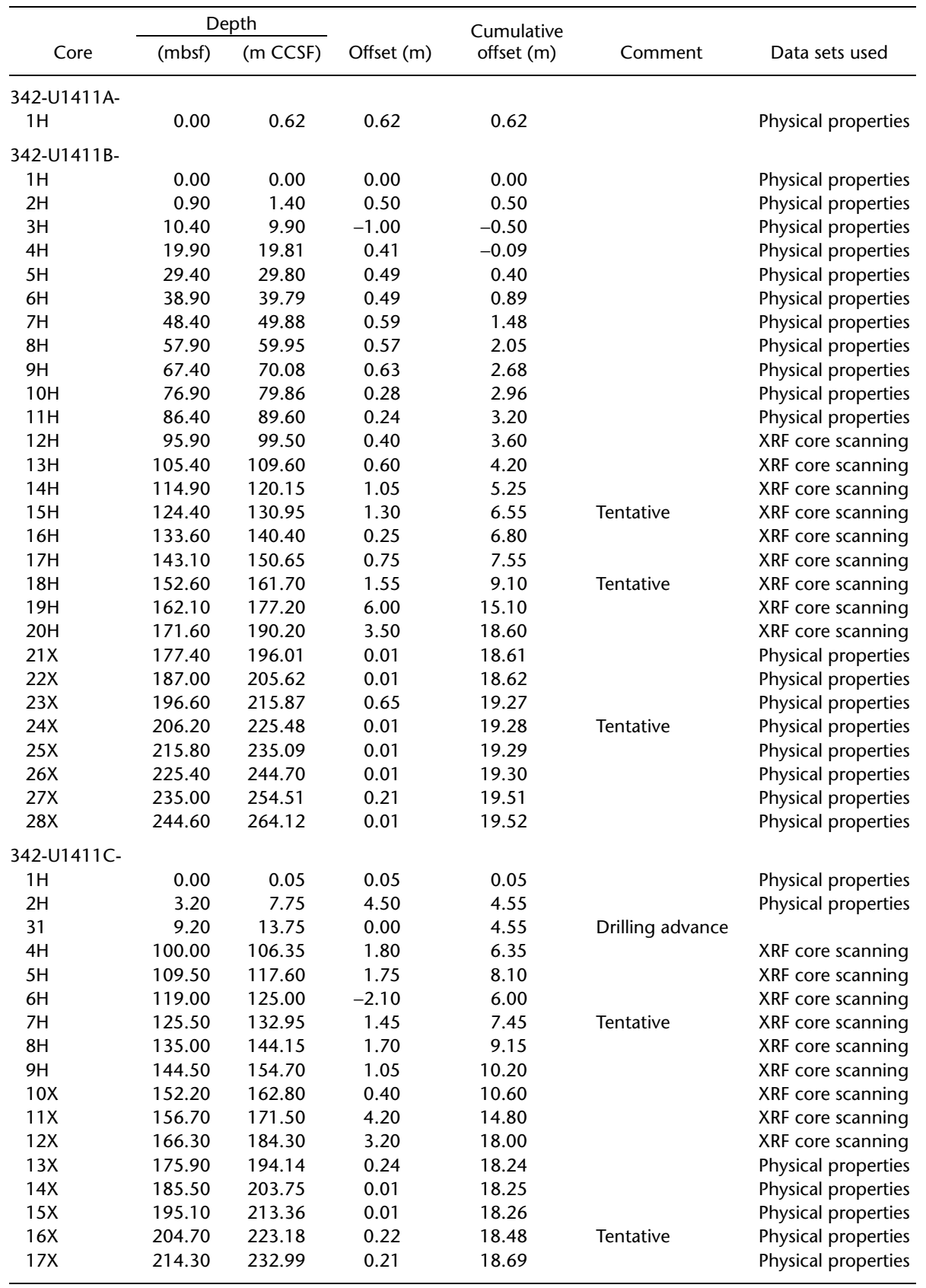

$\mathrm{XRF}=\mathrm{X}$-ray fluorescence. 
Table T20. Splice tie points, Site U1411.

\begin{tabular}{|c|c|c|c|c|c|c|c|c|}
\hline \multirow{2}{*}{$\begin{array}{l}\text { Hole, core, section, } \\
\text { interval }(\mathrm{cm})\end{array}$} & \multicolumn{2}{|c|}{ Depth } & & \multirow{2}{*}{$\begin{array}{l}\text { Hole, core, section, } \\
\text { interval }(\mathrm{cm})\end{array}$} & \multicolumn{2}{|c|}{ Depth } & \multirow[b]{2}{*}{ Comment } & \multirow[b]{2}{*}{ Data sets used } \\
\hline & (mbsf) & (m CCSF) & & & (mbsf) & (m CCSF) & & \\
\hline \multirow[t]{2}{*}{$342-$} & & & & $342-$ & & & & \\
\hline & & & & U1411C-1H-1, 0 & 0.00 & 0.00 & & \\
\hline U1411C-1H-2, 105 & 2.55 & 2.60 & Tie to & U1411B-2H-1, 120 & 2.10 & 2.60 & & Physical properties \\
\hline U1411B-2H-6, 15 & 8.55 & 9.05 & Tie to & U1411C-2H-1, 130 & 4.50 & 9.05 & & Physical properties \\
\hline $\mathrm{U} 1411 \mathrm{C}-2 \mathrm{H}-4,10$ & 7.80 & 12.35 & Tie to & U1411B-3H-2, 95 & 12.85 & 12.35 & & Physical properties \\
\hline U1411B-3H-CC, 29 & 20.30 & 19.80 & Append to & U1411B-4H-1, 0 & 19.90 & 19.81 & & Physical properties \\
\hline U1411B-4H-CC, 24 & 29.88 & 29.79 & Append to & U1411B-5H-1, 0 & 29.40 & 29.80 & & Physical properties \\
\hline U1411B-5H-CC, 30 & 39.38 & 39.78 & Append to & U1411B-6H-1, 0 & 38.90 & 39.79 & & Physical properties \\
\hline U1411B-6H-CC, 37 & 48.98 & 49.87 & Append to & U1411B-7H-1, 0 & 48.40 & 49.88 & & Physical properties \\
\hline U1411B-7H-CC, 37 & 58.46 & 59.94 & Append to & U1411B-8H-1, 0 & 57.90 & 59.95 & & Physical properties \\
\hline U1411B-8H-CC, 39 & 68.02 & 70.07 & Append to & U1411B-9H-1, 0 & 67.40 & 70.08 & & Physical properties \\
\hline U1411B-9H-CC, 44 & 77.17 & 79.85 & Append to & U1411B-10H-1, 0 & 76.90 & 79.86 & & Physical properties \\
\hline U1411B-10H-CC, 20 & 86.63 & 89.59 & Append to & U1411B-11H-1, 0 & 86.40 & 89.60 & & Physical properties \\
\hline U1411B-11H-CC, 54 & 96.29 & 99.49 & Append to & U1411B-12H-1, 0 & 95.90 & 99.50 & & Physical properties \\
\hline U1411B-12H-7, 8 & 104.50 & 108.10 & Tie to & U1411C-4H-2, 25 & 101.75 & 108.10 & & XRF core scanning \\
\hline U1411C-4H-6, 114 & 108.65 & 115.00 & Tie to & U1411B-13H-4, 89 & 110.80 & 115.00 & & XRF core scanning \\
\hline U1411B-13H-7, 36 & 114.80 & 119.00 & Tie to & U1411C-5H-2, 57 & 110.90 & 119.00 & & XRF core scanning \\
\hline U1411C-5H-6, 50 & 116.20 & 124.30 & Tie to & U1411B-14H-3, 115 & 119.05 & 124.30 & & XRF core scanning \\
\hline U1411B-14H-5, 114 & 122.04 & 127.29 & Tie to & $\mathrm{U} 1411 \mathrm{C}-6 \mathrm{H}-3,84$ & 121.29 & 127.29 & & XRF core scanning \\
\hline U1411C-6H-7, 90 & 125.29 & 131.29 & Tie to & U1411B-15H-1, 34 & 124.74 & 131.29 & Small overlap & XRF core scanning \\
\hline U1411B-15H-4, 114 & 129.90 & 136.45 & Tie to & U1411C-7H-3, 50 & 129.00 & 136.45 & & XRF core scanning \\
\hline U1411C-7H-6, 55 & 133.55 & 141.00 & Tie to & U1411B-16H-1, 60 & 134.20 & 141.00 & & XRF core scanning \\
\hline U1411B-16H-4, 80 & 138.90 & 145.70 & Tie to & U1411C-8H-2, 5 & 136.55 & 145.70 & & XRF core scanning \\
\hline U1411C-8H-6, 78 & 143.28 & 152.43 & Tie to & U1411B-17H-2, 28 & 144.88 & 152.43 & & XRF core scanning \\
\hline U1411B-17H-5, 135 & 150.45 & 158.00 & Tie to & U1411C-9H-3, 38 & 147.80 & 158.00 & & XRF core scanning \\
\hline U1411C-9H-5, 124 & 151.58 & 161.78 & Tie to & U1411B-18H-1, 8 & 152.68 & 161.78 & Small overlap & XRF core scanning \\
\hline U1411B-18H-7, 70 & 162.30 & 171.40 & Append to & U1411C-11X-1, 0 & 156.70 & 171.50 & & XRF core scanning \\
\hline U1411C-11X-6, 76 & 164.96 & 179.76 & Tie to & U1411B-19H-2, 106 & 164.66 & 179.76 & & XRF core scanning \\
\hline U1411B-19H-5, 150 & 169.60 & 184.70 & Tie to & U1411C-12X-1, 40 & 166.70 & 184.70 & & XRF core scanning \\
\hline U1411C-12X-6, 82 & 174.62 & 192.62 & Tie to & U1411B-20H-2, 92 & 174.02 & 192.62 & & XRF core scanning \\
\hline U1411B-20H-4, 124 & 177.34 & 195.94 & Append to & U1411C-15X-1, 0 & 195.10 & 213.36 & & Physical properties \\
\hline U1411C-15X-5, 93 & 202.03 & 220.29 & Tie to & U1411B-23X-3, 142 & 201.02 & 220.29 & & Physical properties \\
\hline U1411B-23X-6, 95 & 205.05 & 224.32 & Tie to & U1411C-16X-1, 114 & 205.84 & 224.32 & Small overlap & Physical properties \\
\hline U1411C-16X-CC, 35 & 214.50 & 232.98 & Append to & U1411C-17X-1, 0 & 214.30 & 232.99 & & Physical properties \\
\hline U1411C-17X-CC, 40 & 223.57 & 242.26 & Append to & U1411B-26X-1, 0 & 225.40 & 244.70 & & Physical properties \\
\hline U1411B-26X-CC, 38 & 235.20 & 254.50 & Append to & U1411B-27X-1, 0 & 235.00 & 254.51 & & Physical properties \\
\hline U1411B-27X-CC, 55 & 243.41 & 262.92 & Append to & U1411B-28X-1, 0 & 244.60 & 264.12 & & Physical properties \\
\hline U1411B-28X-CC, 46 & 254.50 & 274.02 & & & & & & \\
\hline
\end{tabular}

$\mathrm{XRF}=\mathrm{X}$-ray fluorescence. 